GEOHYDROLOGY AND CHEMICAL QUALITY OF WATER IN MIDDLE AND UPPER

JURASSIC AND LOWER CRETACEOUS ROCKS, WESTERN KANSAS

By Jack Kume

U.S. GEOLOGICAL SURVEY

Water-Resources Investigations Report 84-4045

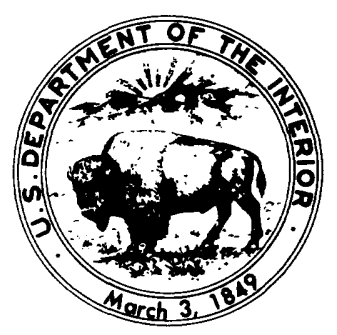

Prepared in cooperation with the

KANSAS DEPARTMENT OF HEALTH AND ENVIRONMENT

Lawrence, Kansas

1984 


\section{UNITED STATES DEPARTMENT OF THE INTERIOR \\ WILLIAM P. CLARK, Secretary \\ GEOLOGICAL SURVEY \\ Dallas L. Peck, Director}

For additional information write to:

District Chief

U.S. Geological Survey

1950 Constant Avenue - Campus West

University of Kansas

Lawrence, Kansas 66046

[Telephone: (913) 864-4321]
Copies of this report can be purchased from:

Open-File Services Section Western Distribution Branch U.S. Geological Survey Box 25425, Federal Center Denver, Colorado 80225 [Telephone: (303) 236-7476] 


\section{CONTENTS}

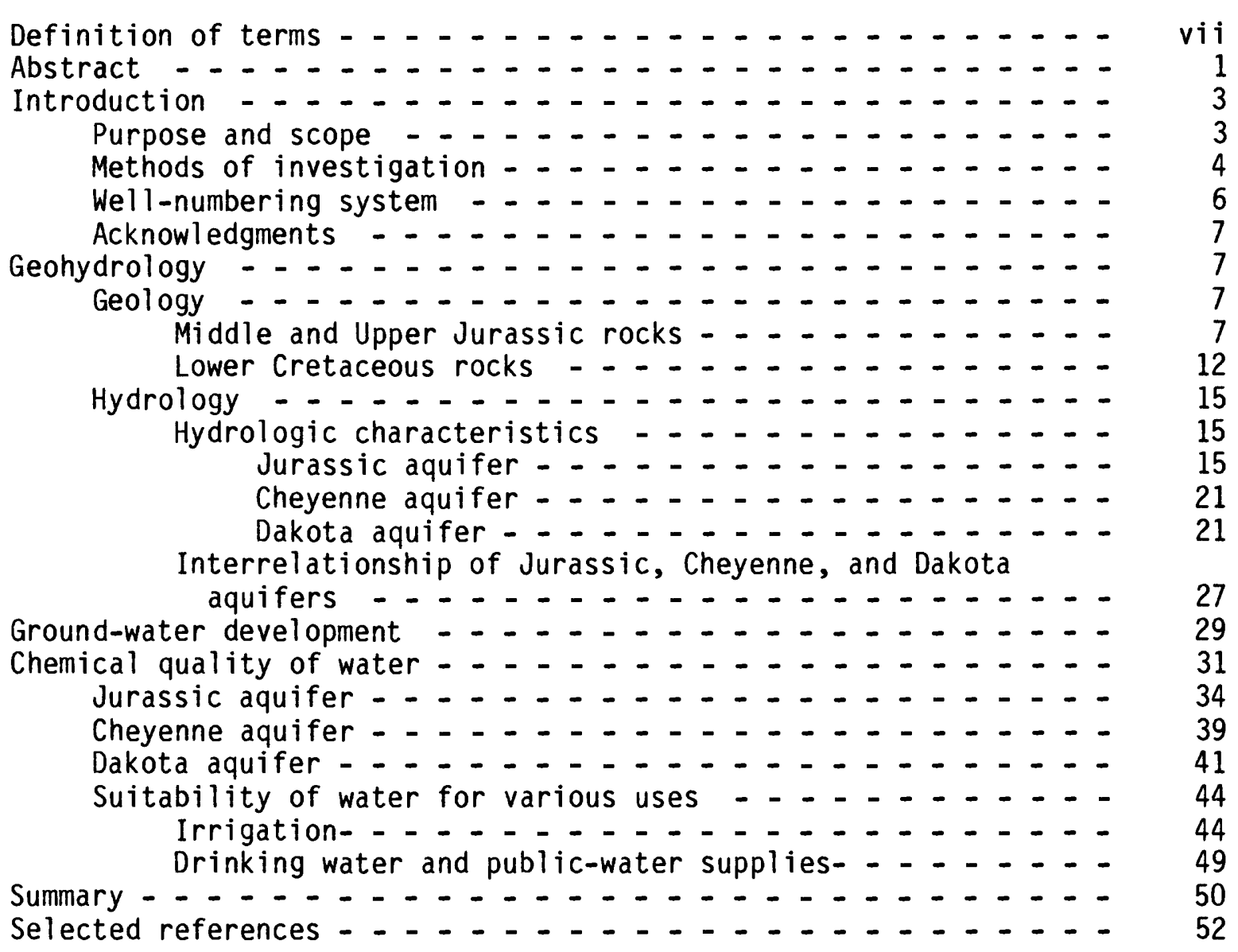

\section{ILLUSTRATIONS}

Figure

Page

1. Map showing location of study area _... . . . . 5

2. Diagram showing well-numbering system - - - - - - - 6

3. Map showing geologic contacts of Upper Permian, Middle and Upper Jurassic, and Lower and Upper Cretaceous rocks, location of selected data-control wells, and traces of geologic

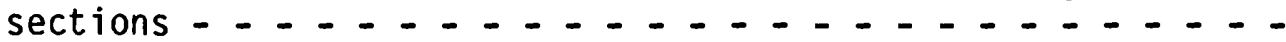

4. Geologic sections of undifferentiated Jurassic and Lower Cretaceous rocks - $\ldots \ldots \ldots$

5. Map showing extent, depth, and thickness of Middle and Upper Jurassic rocks _..................... 


\section{ILLUSTRATIONS--Continued}

Figure

6. Map showing extent, depth, and thickness of Cheyenne Sand-

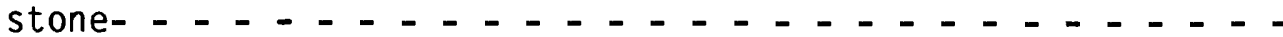

7. Map showing extent, depth, and thickness of Dakota

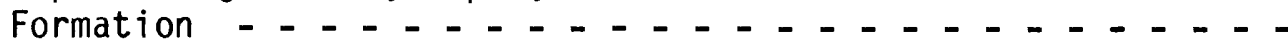

8. Sketch showing geophysical-log correlation of Grilliot, Burnett, and Williamson test wells _ . - . . . - . . . - -

9. Map showing altitude of potentiometric surface of Jurassic aquifer, September-November 1981 - _ - _ - _ - . - 20

10. Map showing altitude of potentiometric surface of Cheyenne aquifer, 1981-82 - - - - - - - - - - - - - -

11. Map showing altitude of potentiometric surface of Dakota

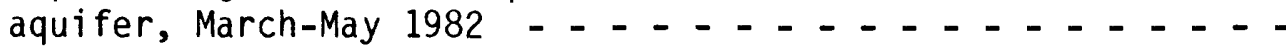

12. Hydrographs showing fluctuations of water levels in selected wells completed in Dakota aquifer, 1972-82 - . . . - . -

13. Bar graph showing comparison of water levels for three test wells completed in the Jurassic, Cheyenne, and Dakota

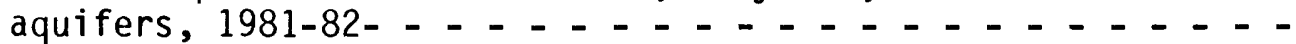

14. Hydrographs showing comparison of fluctuations in water levels for wells completed in the High Plains or Dakota aquifers, 1980-82 _. - . . . . . . . . . . -

15. Bar graph showing chemical composition of water from selected wells completed in Jurassic aquifer - . - . - . - . -

16. Bar graph showing chemical composition of water from selected wells completed in Cheyenne aquifer _ _ . . . . . - .

17. Bar graphs showing chemical composition of water from selected well s completed in Dakota aquifer _ . . . . . . . . -

18. Map showing generalized distribution of dissolved-solids concentrations in water in Dakota aquifer- - . - . - . -

19. Map showing occurrence of chemical types of water in Dakota aquifer

20. Diagram showing classification of selected water samples in Dakota aquifer describing suitability for irrigation - - - - 


\section{TABLES}

Table

Page

1. Generalized stratigraphic section of geologic formations

and their water-yielding properties - _ . . . . . . . 10

2. Summary of data from three test wells _ _ . . . . . 19

3. Summary of selected aquifer tests in the Dakota aquifer - - 24

4. Results of chemical analyses of water from the Jurassic,

Cheyenne, and Dakota aquifers _. . . . . . . . . . 32

5. Summary of chemical analyses of water from the Jurassic,

Cheyenne, and Dakota aquifers _. . . . . . . . . 35

6. Sodium-adsorption-ratio, specific conductance, salinity

hazard, and sodium hazard of water from selected wells com-

pleted in the Dakota aquifer _ . . . . . . . . . . .

\section{CONVERSION TABLE}

Inch-pound units used in this report may be converted to the International System of Units (SI) by the following factors:

Multiply inch-pound unit

foot $(f t)$

mile (mi)

acre

square mile $\left(m i^{2}\right)$

4,047

2.590

gallon (gal)

foot per mile (ft/mi)

gallon per minute (gal/min)

Temperature

degree Fahrenheit $\left({ }^{\circ} \mathrm{F}\right)$

${ }^{\circ} \mathrm{C}=5 / 9\left({ }^{\circ} \mathrm{F}-32\right)$

Specific capacity

gallon per minute per foot

$[(\mathrm{gal} / \mathrm{min}) / \mathrm{ft}]$
By

Length

0.3048

1.609

Area

Volume

3.785

Flow

0.1894

0.06308

degree Celsius $\left({ }^{\circ} \mathrm{C}\right)$

To obtain SI unit

meter (m)

kilometer $(\mathrm{km})$

square meter $\left(\mathrm{m}^{2}\right)$

square kilometer $\left(\mathrm{km}^{2}\right)$

liter (L)

meter per kilometer

$(\mathrm{m} / \mathrm{km})$

liter per second (L/s)

0.2070

liter per second per meter $[(\mathrm{L} / \mathrm{s}) / \mathrm{m}]$ 
Multiply inch-pound unit

Specific conductance

micromho per centimeter at $\quad 1.000$ at $25^{\circ}$ Celsius

( $\mu$ mhos $/ \mathrm{cm}$ at $25^{\circ} \mathrm{C}$ )

foot per day (ft/d)

foot squared per day $\left(\mathrm{ft}^{2} / \mathrm{d}\right) \quad 0.09290$

\section{Hydraulic conductivity}

To obtain SI unit

microsiemens per centimeter at $25^{\circ}$ Celsius $\left(\mu \mathrm{S} / \mathrm{cm}\right.$ at $\left.25^{\circ} \mathrm{C}\right)$

\begin{tabular}{ccc} 
foot per day $(\mathrm{ft} / \mathrm{d})$ & 0.3048 & meter per day $(\mathrm{m} / \mathrm{d})$ \\
\cline { 2 - 2 } & $\frac{\text { Transmissivity }}{0.09290}$ & $\begin{array}{c}\text { meter squared per day } \\
\left(\mathrm{m}^{2} / \mathrm{d}\right)\end{array}$
\end{tabular}

\section{DEFINITION OF TERMS}

Aquifer - A formation, group of formations, or part of a formation that contains sufficient saturated permeable material to yield significant quantities of water to wells and springs (Lohman and others, 1972, p. 2).

Artesian aquifer - A confined water body (Lohman and others, 1972, p. 2); an aquifer bounded above and below by impermeable beds or distinctly lower permeability than that of the aquifer itself. Ground water is under pressure significantly greater than that of the atmosphere (Gary and others, 1972, p. 40 and 148).

Borehole geophysics - All techniques of lowering sensing devices down a well or test hole and recording some physical characteristic that may be interpreted in terms of the characteristics of the rocks, the fluid contained in the rocks, and the construction of the well (Keys and MacCary, 1971, p. 1).

Conductivity, hydraulic - In an isotropic porous medium in which the fluid is homogeneous, hydraulic conductivity is the volume of water at the existing kinematic viscosity that will move in unit time under a unit hydraulic gradient through a unit area measured at right angles to the direction of flow (Lohman and others, 1972, p. 4).

Classification of water for irrigation - definition from U.S. Salinity Laboratory Staff (1954):

Low-salinity water (Cl) - Water can be used for irrigation with little likelihood that soil salinity will develop. 
Classification of water for irrigation--Continued

Medium-salinity water (C2) - Water can be used if a moderate amount of leaching occurs.

High-salinity water (C3) - Water cannot be used on soils with restrictive drainage; special management for salinity control may be required; and plants with good salt tolerance should be selected.

Very high-salinity water (C4) - Water is not suitable for irrigation purposes under ordinary conditions.

Low-sodium water (S1) - Water can be used for irrigation with little danger of the development of harmful levels of exchangeable sodium in the soil.

Medium-sodium water (S2) - Water will present an appreciable sodium hazard in fine-textured soil that has a high cation-exchange capacity, unless gypsum is present in the soil. Medium-sodium water can be used on coarse-textured or organic soils with good permeability.

High-sodium water (S3) - Water may produce harmful levels of exchangeable sodium in most soils and will require special soil management, good drainage, high leaching, and organic conditions.

Very high-sodium water (S4) - Water is generally unsatisfactory for irrigation purposes except at low and perhaps medium-salinity levels.

Classification of quality of water - based on concentration of chloride, from Kansas State Corporation Commission (1979, p. 17):

Freshwater - concentration of not more than 500 milligrams per liter of chloride.

Usable water - concentration of more than 500 milligrams per liter but less than 5,000 milligrams per liter of chloride.

Classification of salinity of water - based on concentration of dissolved solids, from Hem $(1970$, p. 219$)$ :

Freshwater - Contains less than 1,000 milligrams per liter of dissolved solids.

Saline water - Contains 1,000 or more milligrams per liter of dissolved solids.

Slightly saline water - Contains from 1,000 to 3,000 milligrams per liter of dissolved solids. 
Classification of salinity of water--Continued

Moderately saline water - Contains more than 3,000 to 10,000 milligrams per liter of dissolved solids.

Very saline water - Contains more than 10,000 to 35,000 milligrams per liter of dissolved solids.

Brine - Contains more than 35,000 milligrams per liter of dissolved solids.

Deflocculate - To convert or break into very fine particles.

Formation - A mappable or traceable body of rock generally characterized by some degree of internal lithologic homogeneity or distinctive lithologic features (Gary and others, 1972, p. 274).

Ground water, confined - Confined ground water is under pressure significantly greater than atmospheric, and the upper limit of the confined water is the bottom of a bed of distinctly lower hydraulic conductivity than that of the material in which the confined water occurs (Lohman and others, 1972, p. 7).

Ground water, unconfined - Unconfined ground water is water in an aquifer that has a water table (Lohman and others, 1972, p. 7).

Hardness of water - A property of water generally related to the water's soap-consuming capacity; hardness is caused by the presence of cations in the water that form insoluble compounds with soap (Hem, 1970, p. 224-225).

Hardness classification

Soft

Moderately hard

Hard

Very hard
Hardness range

(milligrams per liter as calcium carbonate)

Head, pressure - The height of a column of static water that can be supported by the static pressure at a given point (Lohman and others, 1972, p. 7-8).

Head, static - The height above a standard datum (sea level) of the surface of a column of water that can be supported by the static pressure at a given point (Lohman and others, 1972, p. 7).

Hydraulic gradient - The change in static head per unit of distance (feet permile or feet per feet, a dimensionless fraction) in a given direction. If not specified, the direction generally is understood to be that of the maximum rate of decrease in head (Lohman and others, 1972, p. 8). 


\section{DEFINITION OF TERMS--Continued}

Hydrograph - A graph showing stage, flow, velocity, or some other characteristic of water with respect to time (Gary and others, 1972, p. $343)$.

Nuclear logs - Radiation logs including natural gamma, gamma-gamma, and neutron logs that are a measurement of fundamental particles or radiations from the nucleus of an atom (Keys and MacCary, 1971, p. 58).

Potable water - Water that is safe and palatable for human use; freshwater that has been treated so as to be tolerably low in objectionable taste, odor, color, and turbidity, and of a temperature suitable for the intended use (Gary and others, 1972, p. 560).

Potentiometric surface - An imaginary surface representing the static head of ground water, defined by the levels to which water will rise in tightly cased wells (Gary and others, 1972, p. 561).

Resistivity - The resistance to the flow of electrical current through material. The electrical resistivity of a rock depends on physical properties of the rock and the fluids the rock contains (Keys and MacCary, 1971, p. 36-38).

Sodium-adsorption-ratio (SAR) - definition from U.S. Salinity Laboratory Staff (1954). Related to the adsorption of sodium from water to the soil to which the water has been added. It is determined by the following relation where sodium $\left(\mathrm{Na}^{+}\right)$, calcium $\left(\mathrm{Ca}^{+} 2\right)$, and magnesium $\left(\mathrm{Mg}^{+2}\right)$ ion concentrations are expressed in milliequivalents per liter:

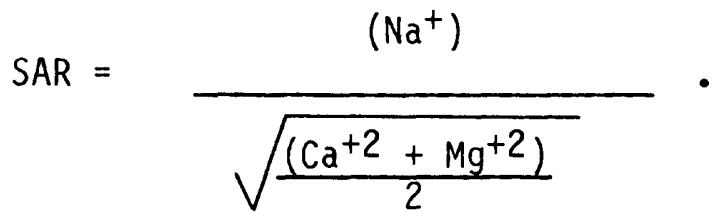

Specific capacity - Rate of discharge of water from a well divided by the drawdown of water level within the well (Lohman and others, 1972, p. 11).

Specific conductance - The ability of a substance to conduct an electric current. Specific conductance is the conductance of a body of unit length and unit cross section at a specified temperature (Hem, 1970, p. 96). Specific conductance can be used as a measure of the concentration of dissolved solids in a water sample.

Storage coefficient - Volume of water an aquifer releases from or takes into storage per unit surface area of the aquifer per unit change in head (Lohman and others, 1972, p. 13).

Subcrop - A geologic formation that occurs directly beneath a substantial break in stratigraphic sequence. 


\section{DEFINITION OF TERMS--Continued}

Transmissivity - The rate at which water of the prevailing kinematic viscosity is transmitted through a unit width of the aquifer under a unit hydraulic gradient (Lohman and others, 1972, p. 13).

Water level, static - The depth to water in a well that represents the unstressed water surface.

Water table - The potentiometric surface in an unconfined aquifer at which the water pressure is atmospheric. The surface is defined by the levels at which water stands in wells that penetrate the aquifer enough to hold standing water (Lohman and others, 1972, p. 14). 


\title{
GEOHYDROLOGY AND CHEMICAL QUALITY OF WATER IN MIDDLE AND UPPER JURASSIC AND LOWER CRETACEOUS ROCKS, WESTERN KANSAS
}

By

Jack Kume

\begin{abstract}
An investigation of permeable units in Middle and Upper Jurassic and Lower Cretaceous rocks was made, in cooperation with the Kansas Department of Health and Environment, to define and update data on the geohydrology and chemical quality of water and to regionalize the results for about 12,700 square miles in 15 counties in western Kansas. The consolidated formations considered include rocks equivalent to the undifferentiated Middle and Upper Jurassic Entrada Sandstone and Morrison Formation and the Lower Cretaceous Cheyenne Sandstone, Kiowa Formation, and Dakota Formation.

The rocks equivalent to the undifferentiated Entrada Sandstone and Morrison Formation occur in the subsurface in the western two-thirds of the area at depths ranging from about 300 to about 2,500 feet. The rocks consist of varicolored sandstone, siltstone, shale, and limestone. Maximum thickness is about 200 feet.

The Cheyenne Sandstone occurs at depths ranging from about 200 to about 2,500 feet in the subsurface throughout the area, except along the south-central boundary. The rocks consist of white, brown, and gray, very fine to medium-grained sandstone and dark-gray shale. Maximum formation thickness is about 200 feet.

The Kiowa Formation occurs in the subsurface throughout the area, except along the south-central boundary. The rocks consist of light-gray to black shale with interbedded siltstone, sandstone, and limestone. Maximum formation thickness is about 190 feet.

The Dakota Formation occurs at the land surface in five counties as isolated outcrops and in the subsurface at depths of more than 2,000 feet in wallace County, except along the south-central boundary. The rocks consist of varicolored sandstone, shale, and siltstone with some lignite. Maximum formation thickness is about 400 feet.

The Jurassic aquifer is defined as permeable and saturated sandstone and siltstone units equivalent to the undifferentiated Entrada Sandstone and Morrison Formation. The maximum total thickness of the sandstone beds is about 50 feet. During 1981, depths to water in three test wells completed in the aquifer ranged from 255 to 1,160 feet; static heads in the artesian aquifer ranged from 2,408 to 3,090 feet above sea level. Porosity of the sandstone tested in the Burnett No. 1 well ranged from about 19 to 25 percent. The hydraulic gradient ranged from 16 feet per mile toward the northeast to 40 feet per mile toward the north.
\end{abstract}


The Cheyenne aquifer is defined as permeable and saturated sandstone units in the Cheyenne Sandstone. The maximum total thickness of the sandstone beds is about 190 feet. During 1981, depths to water in three test wells completed in the aquifer ranged from 267 to 375 feet; static heads in the artesian aquifer varied from less than 2,300 to more than 3,200 feet above sea level. Porosity of the sandstone tested in Burnett No. 1 well ranged from about 23 to 32 percent. The hydraulic gradient was toward the east at 8 feet per mile.

The Dakota aquifer is defined as saturated permeable sandstone units in the Dakota Formation. The maximum total thickness of the sandstone beds is about 150 feet. During 1982, depths to water in wells completed in the aquifer ranged from 24 to 604 feet; static heads in the artesian aquifer ranged from about 2,100 to 3,200 feet. The hydraulic gradient was toward the east and northeast at 11 feet per mile. Transmissivity ranged from about 100 to 2,100 feet squared per day; specific capacity, from about 2.5 to 13 gallons per minute per foot of drawdown; storage coefficients, from $1 \times 10^{-4}$ to $4 \times 10^{-3}$; and well yields, from about 150 to 1,200 gallons per minute.

Water in the Jurassic aquifer, where sampled in Hamilton and Kearny Counties, is moderately saline, very hard, and unsuitable for drinking and irrigation. Sodium is the predominant cation in the water, and sulfate and chloride are the predominant anions. The most likely sources of saline water are from the natural dissolution of minerals and from interstitial saline water.

Water in the Cheyenne aquifer, where sampled in Hamilton and Kearny Counties, is fresh to moderately saline, locally can vary from soft to very hard, and is suitable to unsuitable for drinking and irrigation. Sodium is the predominant cation, and sulfate and bicarbonate are the predominant anions.

Water in the Dakota aquifer, where sampled in five counties, generally is fresh, soft to very hard, and suitable for drinking and irrigation. However, the water is slightly to moderately saline, soft to moderately hard, and unsuitable for drinking and irrigation in parts of Hamilton County. Sodium and calcium are the predominant cations, and bicarbonate, sulfate, and chloride are the predominant anions. The chemical type of water may vary locally. The slightly saline waters are sodium sulfate and sodium chloride types, and the moderately saline water is a calcium sulfate type.

Ground water in all three aquifers is suitable for various uses that include domestic, stock, irrigation, public, and industrial water systems. The Jurassic and Cheyenne aquifers generally have had very little well development; however, the Dakota aquifer has had considerable development, but it is still considered underdeveloped in most localities. 


\section{INTRODUCTION}

Economic stability or growth in western Kansas depends on the continued availability of ground water for irrigation, municipal, industrial, stock, and domestic uses. The production of food and fiber from irrigated land in this region is of major significance to the economic well being of Kansas and the Nation. However, the High Plains unconsolidated aquifer of Tertiary and Quaternary age, the principal source of ground water, has been stressed extensively by pumpage in much of western Kansas. The underlying Middle and Upper Jurassic and Lower Cretaceous consolidated rocks contain permeable units that may have a potential for use as alternative sources of water supply. These permeable units, generally sandstones, are beginning to be used for water supply to supplement water from the High Plains aquifer. However, the hydraulic characteristics of the permeable sandstone units, their location in the stratigraphic section, the static-head difference between units, the hydrologic relationship between permeable units and confining units, the quality of water, and the factors controlling the vertical and horizontal changes in quality of water within the rock section are not well defined.

Underlying the Jurassic and Cretaceous rocks are Permian rocks that contain oil and gas in parts of western Kansas. Therefore in the areas containing oil and gas, test or production wells generally penetrate the Jurassic and Cretaceous rocks. The uppermost gas zones in Permian rocks are the Chase and Council Grove Groups encountered at about 800 and 1,200 feet, respectively, below the base of the Jurassic rocks (William R. Bryson, Kansas Department of Health and Environment, written commun., 1984). These gas zones comprise the Hugoton and Council Grove Gas Fields. Bryson (written commun., 1984) states that in the area of study, there has been no oilfieldbrine disposal into either the Cretaceous or Jurassic rocks except for an isolated location in Hodgeman County and that the highest formation ever used for oilfield-brine disposal occurs at the base of the Day Creek Dolomite in Permian rocks.

In some areas in western Kansas, the permeable units within the Jurassic and Cretaceous section are used as sources of water supply for secondary oil and gas recovery, irrigation, and industry. In southwestern Kansas, irrigation wells commonly are completed in the High Plains aquifer as well as in the sandstone units in Middle and Upper Jurassic and Lower Cretaceous rocks.

\section{Purpose and Scope}

The objective of the study was to define and update data on the geohydrology and chemical quality of water in permeable units in Middle and Upper Jurassic and Lower Cretaceous rocks and to regionalize the results. This study attempted to: (1) Extend the knowledge of the vertical and horizontal variation in chemical quality of water in the permeable units, (2) determine the static-head differences between and across the permeable units, and (3) determine hydraulic characteristics of the permeable units. 
This report presents the results of a geohydrologic and chemicalquality-of-water study of the permeable units in Middle and Upper Jurassic and Lower Cretaceous rocks in western Kansas. The study area includes 15 counties and comprises about $12,700 \mathrm{mi}^{2}$ (fig. 1). The value of this report is to provide the State with geohydrologic insight and aquifer quality-of-water data that can be used to better protect freshwater aquifers during drilling. The study was conducted during 1979-82 in cooperation with the Kansas Department of Health and Environment.

\section{Methods of Investigation}

The investigation began with the interpretation of lithologic and borehole geophysical logs of oil and gas exploratory wells and the analysis of data from previous and ongoing studies to define the geohydrologic characteristics, thickness, and extent of permeable units of Middle and Late Jurassic and Early Cretaceous age. After a thorough evaluation of the data compiled during the initial phase of the study, three plugged and abandoned $0 i l$ and gas test wells that were cased from the land surface into or below the Middle and Upper Jurassic rocks were selected by geographic location and site accessibility for possible use as test wells.

An experimental approach was used to obtain maximum data from three of the possible test wells with mimimum costs. A drilling contract was awarded to: (1) Re-enter the plugged oil and gas test wells, (2) drill out the plugging materials, (3) wash out the well casings, (4) set concrete plugs to isolate selected permeable units, (5) perforate the casings at three selected intervals in the aquifers, (6) cement off perforated casing intervals after testing had been completed, (7) develop the aquifers by bailing water from the well casings, (8) collect water samples for chemical analyses from selected perforated casing intervals, and (9) measure the static head in each well.

After the test wells were selected and permission was granted from the 1 and owners and the Kansas State Corporation Commission to re-open the wells, the surface pipes were measured on a plat and staked at the sites by an oilfield surveyor. The casings were pinpointed at each site by the use of a magnetic locator. Because the tops of the abandoned casings had been cut off and usually were buried by 2 to $4 \mathrm{ft}$ of soil, a backhoe, bulldozer, or hand shovel was used to expose the tops of the pipes. An extension pipe was welded to the top of each well casing so that the casing tops extended above the land surface. After the plugging material was drilled and washed out of each well casing to the selected total depth, borehole geophysical logs, such as a gamma-ray collar or gamma-ray neutron collar, were obtained. The logs were used to select three permeable zones to be perforated, developed, and sampled.

Standard complete chemical analyses of water collected from selected wells were made by the Kansas Department of Health and Environment laboratory in Topeka and by the U.S. Geological Survey laboratory in Arvada, Colorado. Analyses for potassium-40, bromide, iodine, total organic carbon, and lithium were made by the U.S. Geological Survey laboratory because the State laboratory did not make these determinations. 


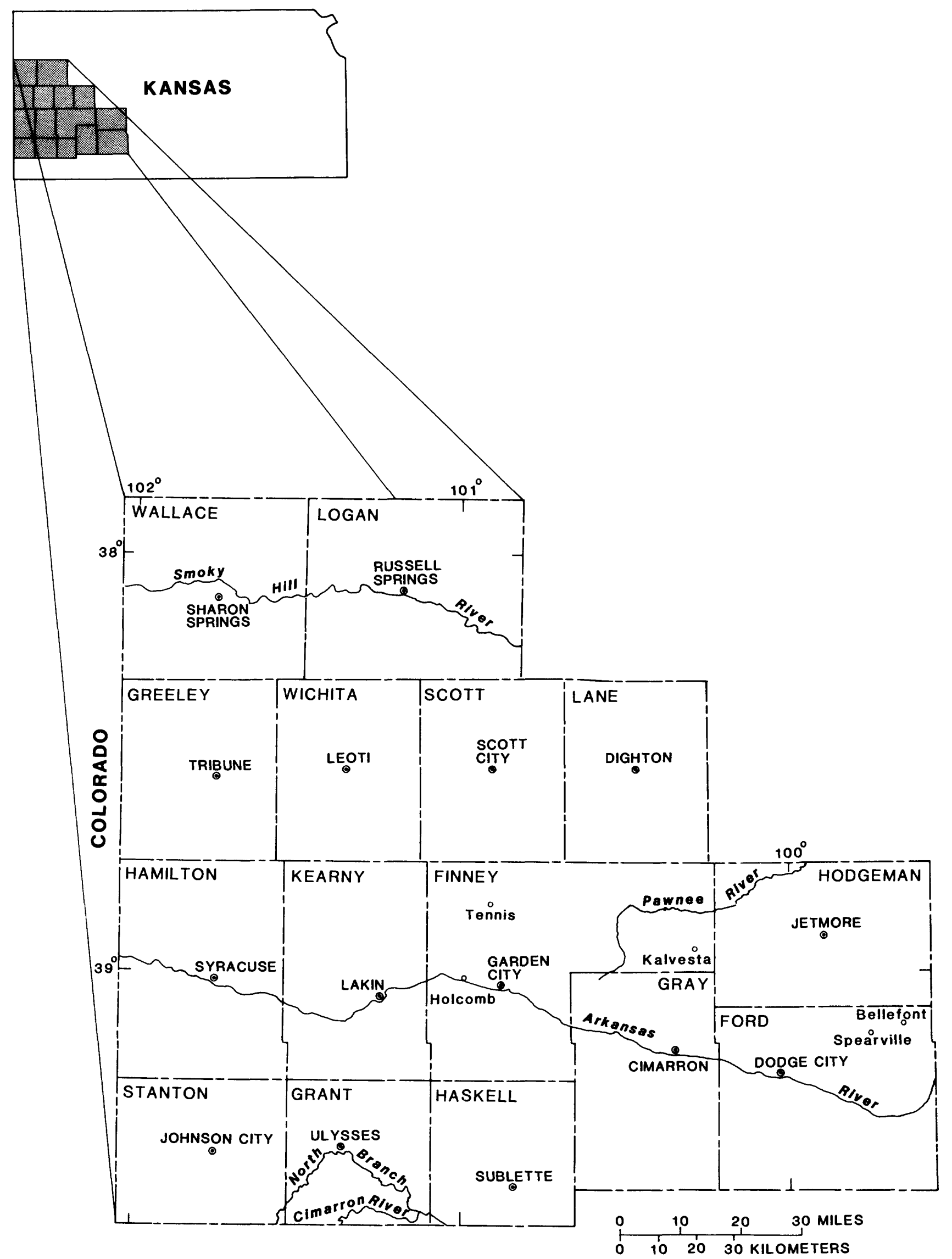

Figure 1.--Location of study area. 
The well-numbering system used in this report, as shown in figure 2, gives the location of a well or test hole according to the U.S. Bureau of Land Management's system of land subdivision. In this system, the first set of digits of a well or test-hole number indicates the township; the second set, the range east or west of the Sixth Principal Meridian; and the third set, the section. The first letter after the section number denotes the quarter section or 160-acre tract; the second, the quarterquarter section, or 40-acre tract; and the third, the quarter-quarterquarter section, or 10-acre tract. The 160-, 40-, and 10-acre tracts are designated $A, B, C$, or $D$ in a counterclockwise direction, beginning in the northeast quadrant. Where two or more wells or test holes are located in a 10-acre tract, consecutive numbers are added, beginning with 2, in the order in which data from the wells or test holes were collected. Thus, in Kearny County, the number 22-35W-4DCC means that the well or test hole is in the SW1/4 SW1/4 SE1/4 sec. 4, T. 22 S., R. 35 W. (fig. 2).

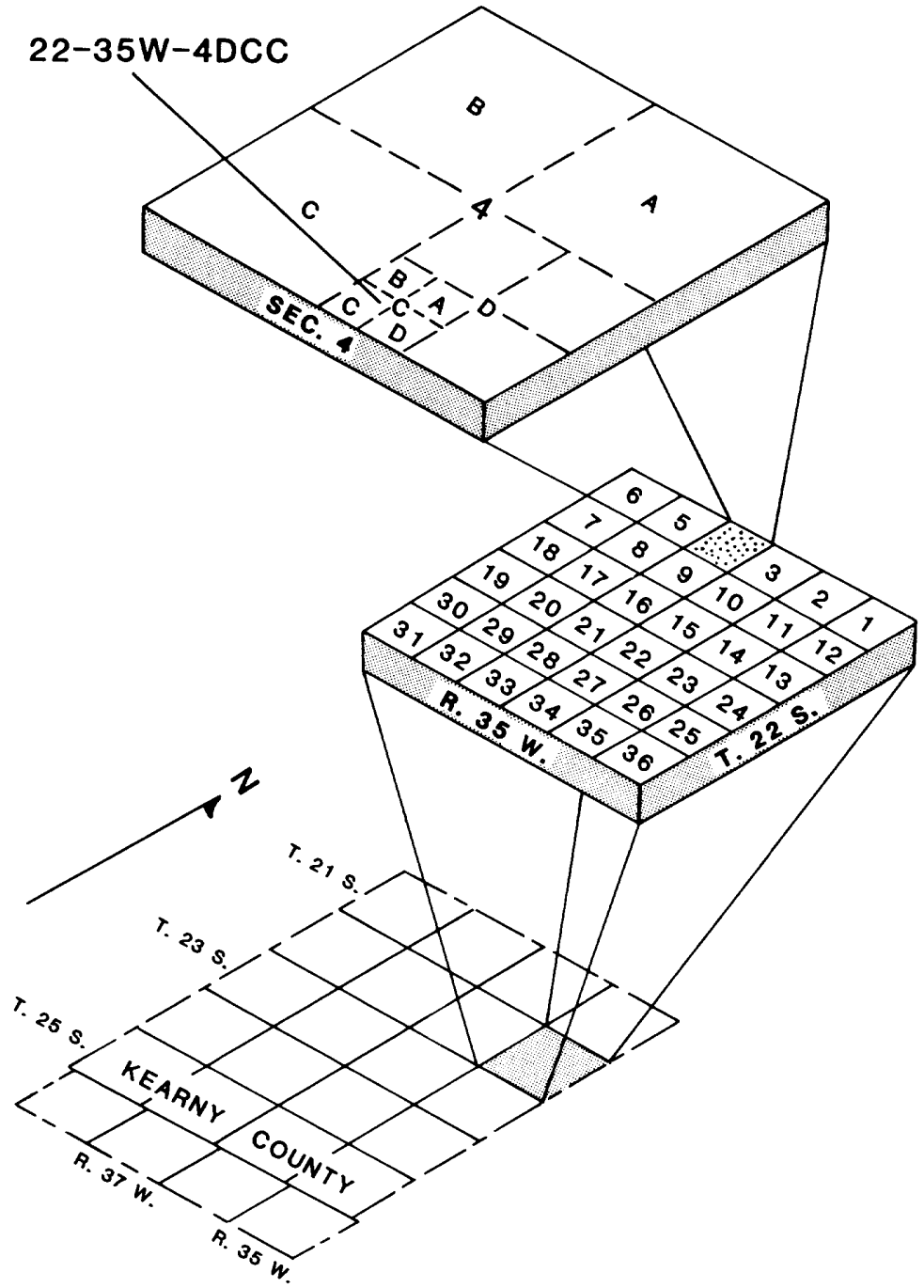

Figure 2.--Well-numbering system. 
Acknowledgments

Appreciation is expressed to the landowners who permitted access to their land and allowed the re-entry and washing out of their plugged and abandoned oil or gas exploratory wells. Additional thanks are extended to these landowners for allowing the intermittent measurement of water levels in these test wells.

Thanks also are extended to other landowners, farm operators, municipal officials, and individuals in the study area who allowed access to their property and wells to make hydrologic measurements and to collect water samples. These people also provided valuable information and assistance for this study.

Drillers' logs and other hydrologic information were provided by several commercial drillers, including Layne-Western Company, Inc., Henkle Drilling and Supply Company, Inc., Minter Wilson Drilling Company, and Fulton Drilling Company. Fulton Drilling Company did the initial drilling phase for the first test well. Layne-Western Company, Inc., successfully completed a drilling contract that included the re-entering, drilling, and washing out of three test-well casings, plus the collection of water samples. Rosel Well Perforators, Inc., was awarded a subcontract to perforate the casings.

Water-level measurements were provided by the Garden City and Stafford offices of the Kansas State Board of Agriculture, Division of Water Resources. Also, appreciation is expressed to Mr. Edward D. Jenkins of the Southwest Kansas Groundwater Management District No. 3 for providing aquifer-test data.

\section{GEOHYDROLOGY}

\section{$\underline{\text { Geology }}$}

The subsurface geologic contacts and formational subcrops of consolidated Upper Permian, Middle and Upper Jurassic, and Lower and Upper Cretaceous rocks are shown in figure 3. Overlying these rocks are unconsolidated Tertiary and Quaternary deposits. An Upper Permian subcrop occurs in a very small area in southeastern Haskell County, and Middle Upper Jurassic subcrops are found in southern Grant, Haskell, and Gray Counties. Lower Cretaceous subcrops occur in a narrow band along the southern and eastern parts of the study area, and Upper Cretaceous subcrops are located throughout the central and northern parts of the area.

The location of data-control wells and the Bear Creek fault also are shown in figure 3. The Bear creek fault is a gravity, tension-type fault that is the result of the dissolution and removal by ground water of evaporites within the Lower Permian rocks (Gutentag and others, 1981, p. 9).

A generalized stratigraphic section of the geologic formations and their water-yielding properties that were considered in this study are 


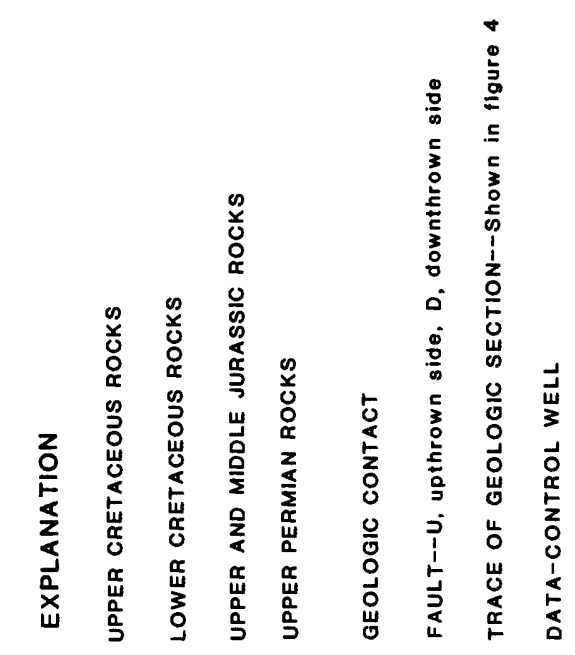

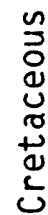

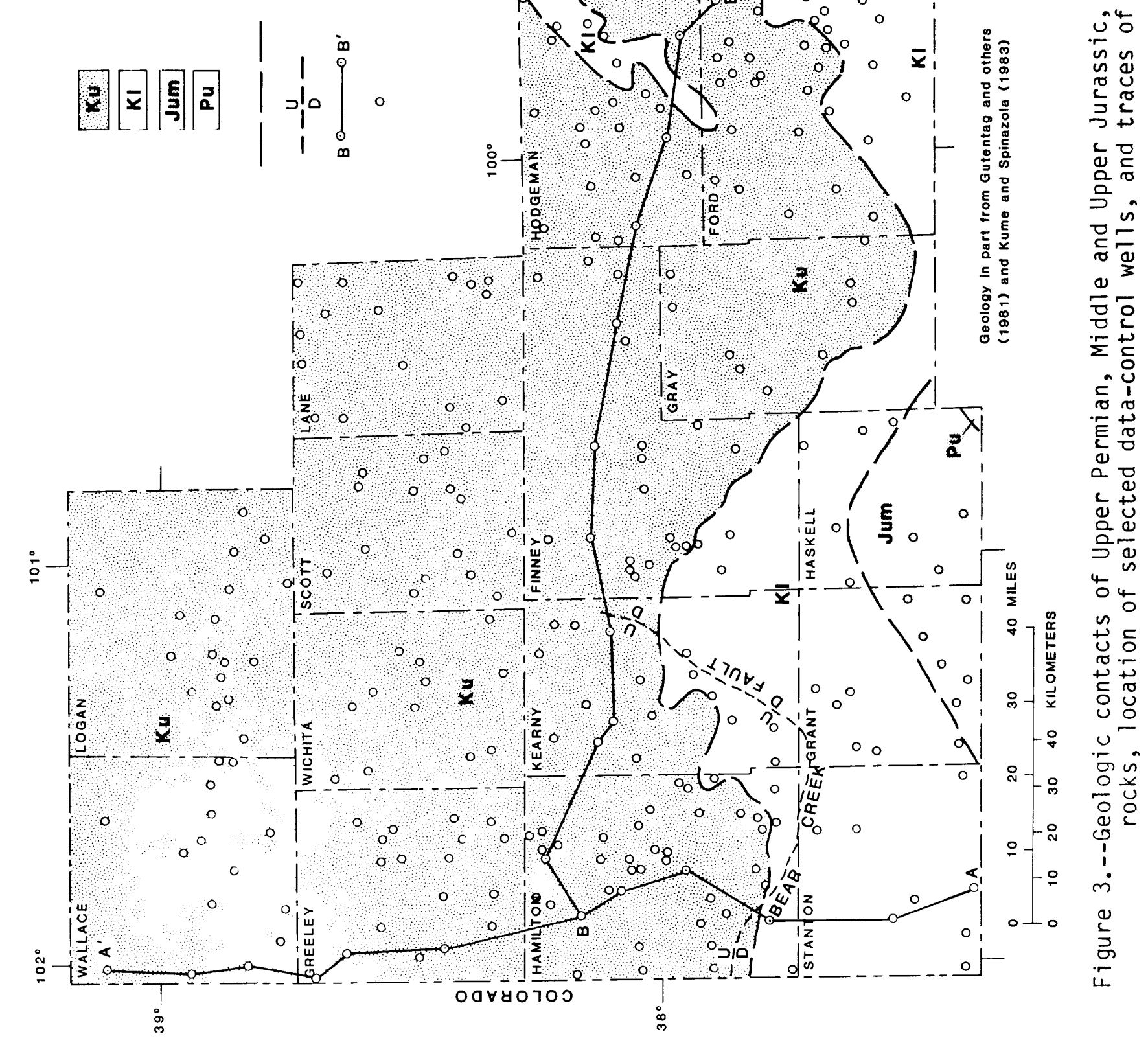


1isted in table 1. Middle and Upper Jurassic rocks include equivalents of the Entrada Sandstone and Morrison Formation. Lower Cretaceous rocks include the Cheyenne Sandstone, Kiowa Formation, and Dakota Formation.

Geologic sections of the undifferentiated Jurassic and Lower Cretaceous rocks considered in the study are shown in figure 4. The traces of geologic section $A-A^{\prime}$, a north-south section along the western border of the area, and geologic section $B-B^{\prime}$, an east-west section across the central part of the area, are shown on the geologic map in figure 3.

Section $A-A^{\prime}$ shows that undifferentiated Jurassic and Lower Cretaceous rocks dip northward at a gradient of about $15 \mathrm{ft} / \mathrm{mi}$ or of about 0.003 (fig. 4). The geologic section also shows that formations occur at an altitude of between 1,300 and 3,300 ft above the National Geodetic Vertical Datum of 1929. The Bear Creek fault in Hamilton County has vertically displaced several formations by as much as $90 \mathrm{ft}$, with the north side of the fault as the uplifted side. The Dakota Formation, the thickest formation, pinches out along its southern limit in Stanton County.

Section $B-B^{\prime}$ shows that undifferentiated Jurassic and Lower Cretaceous rocks from Hamilton County to central Finney County dip to the east at a gradient of about $17 \mathrm{ft} / \mathrm{mi}$ or about 0.003 (fig. 4). The section also shows that from eastern Finney County to Hodgeman County these formations are either relatively flat or dip gently to the west. Along the section, the formations occur at an altitude of between 1,500 and 3,000 $\mathrm{ft}$ above the National Geodetic Vertical Datum of 1929. The Bear Creek fault in Kearny County has vertically displaced several formations by as much as 50 $\mathrm{ft}$, with the west side of the fault as the uplifted side. The rocks equivalent to undifferentiated Entrada Sandstone and Morrison Formation pinch out to the east in eastern Finney County. The Cheyenne Sandstone and the Dakota Formation are thickest in Hodgeman County (see section B-B').

\section{Middle and Upper Jurassic Rocks}

Middle and Upper Jurassic rocks were deposited during a continental and fluvial environment. The distribution and position of the clastic materials indicate a source of the stream sediments to the southeast. Small lakes and backwater areas also must have developed on low, flat marginal-stream areas in which anhydrite accumulated under desiccating conditions. Deltaic deposition also occurred at this time. Finally, a volcanic ash fall occurred that altered the clastic materials into a chert (Merriam, 1963, p. 73).

Differentiation of the rocks of the Middle and Late Jurassic age into the Entrada Sandstone and the Morrison Formation within the study area is difficult, and more detailed study and information are needed before differentiation can be accomplished. Locally, and mainly by borehole geophysicallog interpretations, the two rock units may be present. A basal sandstone unit (probably equivalent to the Entrada Sandstone) and an upper siltstone, shale, or sandstone unit (probably equivalent to the Morrison Formation) may be present locally. In other areas, only the upper unit appears to be present. 


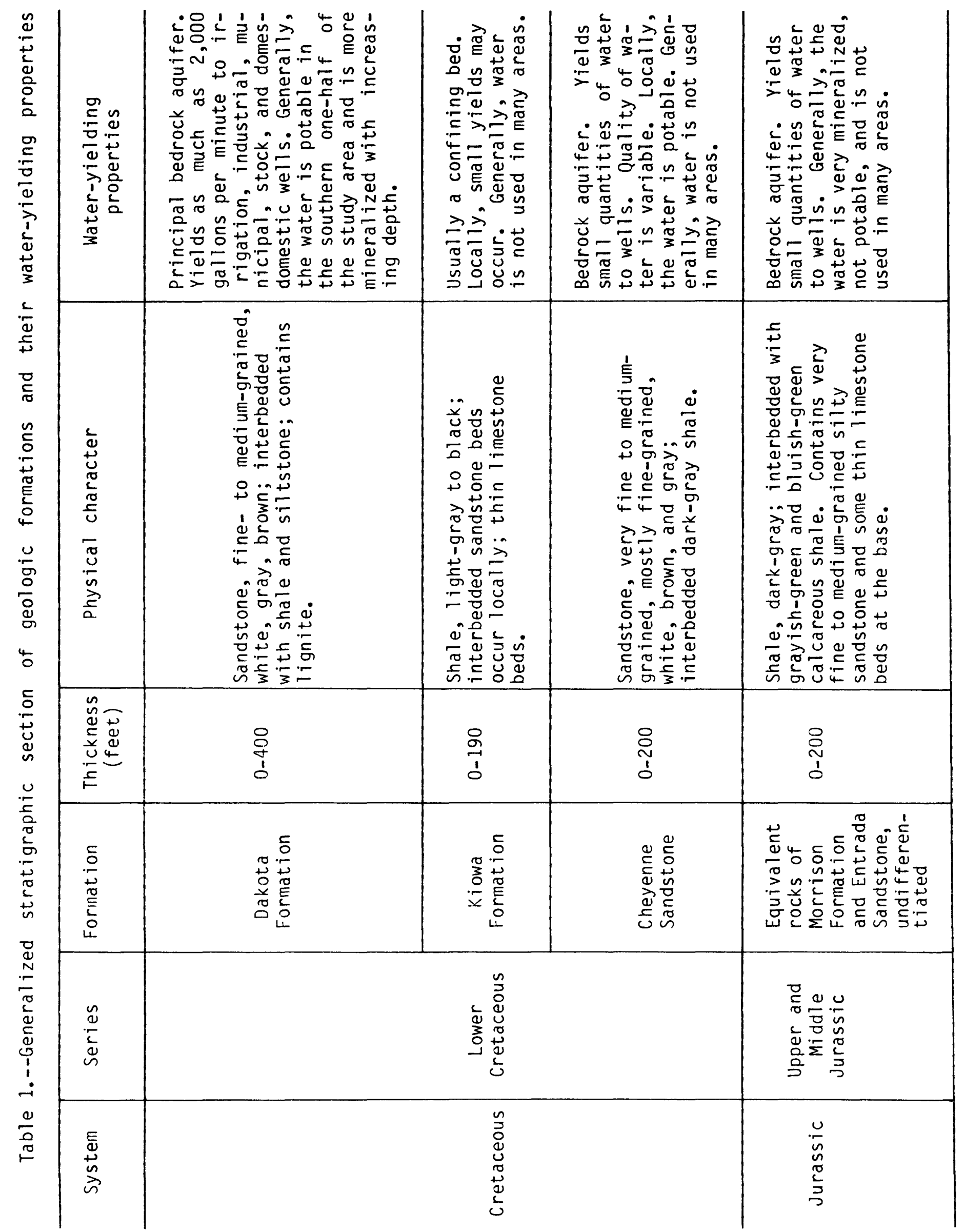




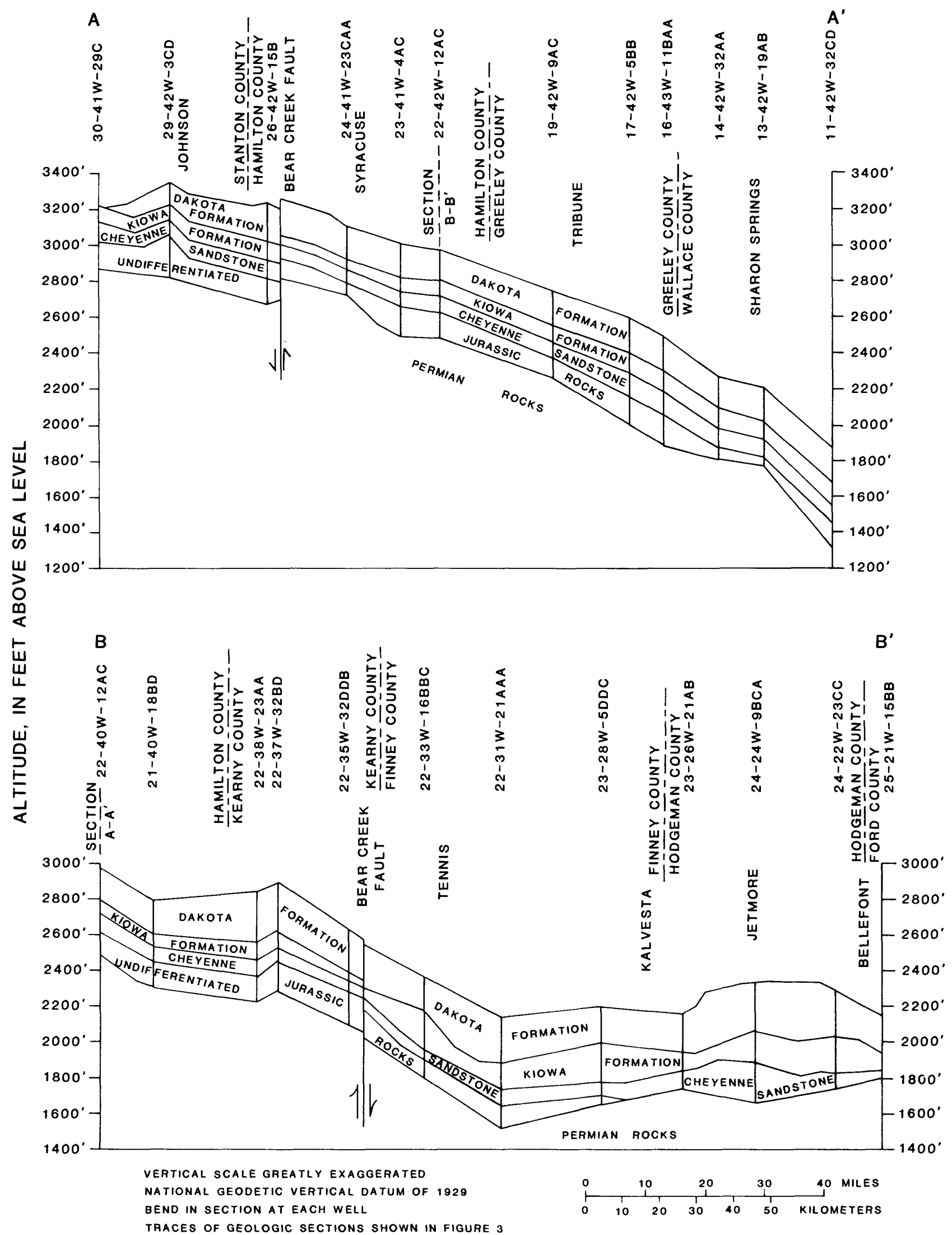

Figure 4.--Geologic sections of undifferentiated Jurassic and Lower Cretaceous rocks. 
In Prowers County, southeastern Colorado, adjacent to Hamilton and Stanton Counties in Kansas, Voegeli and Hershey (1965) subdivided rocks, then called Upper Jurassic rocks, into three units that included a basal unit [the Entrada Sandstone, now called Middle Jurassic (C. B. Davidson, U.S. Geological Survey, written commun., 1984)], a middle unit, and an upper unit (the Morrison Formation). The basal and upper units probably can be recognized locally in southwestern Kansas. Red siltstones interbedded with buff, green, and white sandstones probably are equivalent to the Entrada Sandstone and Morrison Formation of southeastern Colorado (Gutentag and others, 1981).

A basal, white, very fine grained sandstone that probably is equivalent to the Entrada Sandstone appears to be present in the subsurface in Greeley, Hamilton, and Kearny Counties. Locally, the sandstone can be distinguished by geophysical-log characteristics. In most of the study area, Upper Jurassic rocks consist of varicolored siltstones, shales, limestones, and sandstones that occur in the subsurface below the Cheyenne Sandstone and above the Permian red beds. According to Merriam (1963), these varicolored rocks probably are equivalent to the Morrison Formation.

The areal extent, depth to the top, and thickness of Middle and Upper Jurassic rocks are shown in figure 5. The rocks unconformably overlie upper Permian rocks in the western two-thirds of the study area. The Jurassic rocks occur only in the subsurface at depths ranging from about $300 \mathrm{ft}$ in southeast Grant County to more than 2,500 ft in northwest Wallace County. The rocks range in thickness from about zero at their eastern limit to more than $200 \mathrm{ft}$ in Greeley, Hamilton, Scott, and Stanton Counties.

Lower Cretaceous Rocks

Lower Cretaceous rocks generally can be diffentiated into a basal sandstone unit, a middle shale unit, and an upper sandstone and shale unit. However, the sandstone units have interbedded shales, and the shale units have interbedded sandstones. In a few local areas, shale predominates throughout the three units. The sediments that comprise these units were deposited in a transgressive-regressive cycle (Franks, 1975). The basal unit (Cheyenne Sandstone) was deposited by southeastwardly flowing streams in a localized alluvial plain and estuarine environment during the transgression of the Early Cretaceous sea. The middle unit (Kiowa Formation) was deposited in and near the margins of the sea with regressive deposits at the top of the unit. The upper unit (Dakota Formation) was deposited initialiy by southwestwardly flow streams in a progradational alluvial plain and deltaic complex, but later sedimentary conditions changed to an increasingly marine aspect (Franks, 1975).

The Cheyenne Sandstone is a very fine to medium-grained, white, brown, or gray sandstone that is interbedded with dark-gray shale. The areal extent, depth to the top, and thickness of the Cheyenne Sandstone are shown in figure 6. The Cheyenne underlies the entire study area, except for the southern parts of Grant and Haskell Counties and the southwest corner of Gray County, and unconformably overlies Middle and Upper Jurassic and upper Permian rocks. The Cheyenne rocks occur only in the subsurface at 


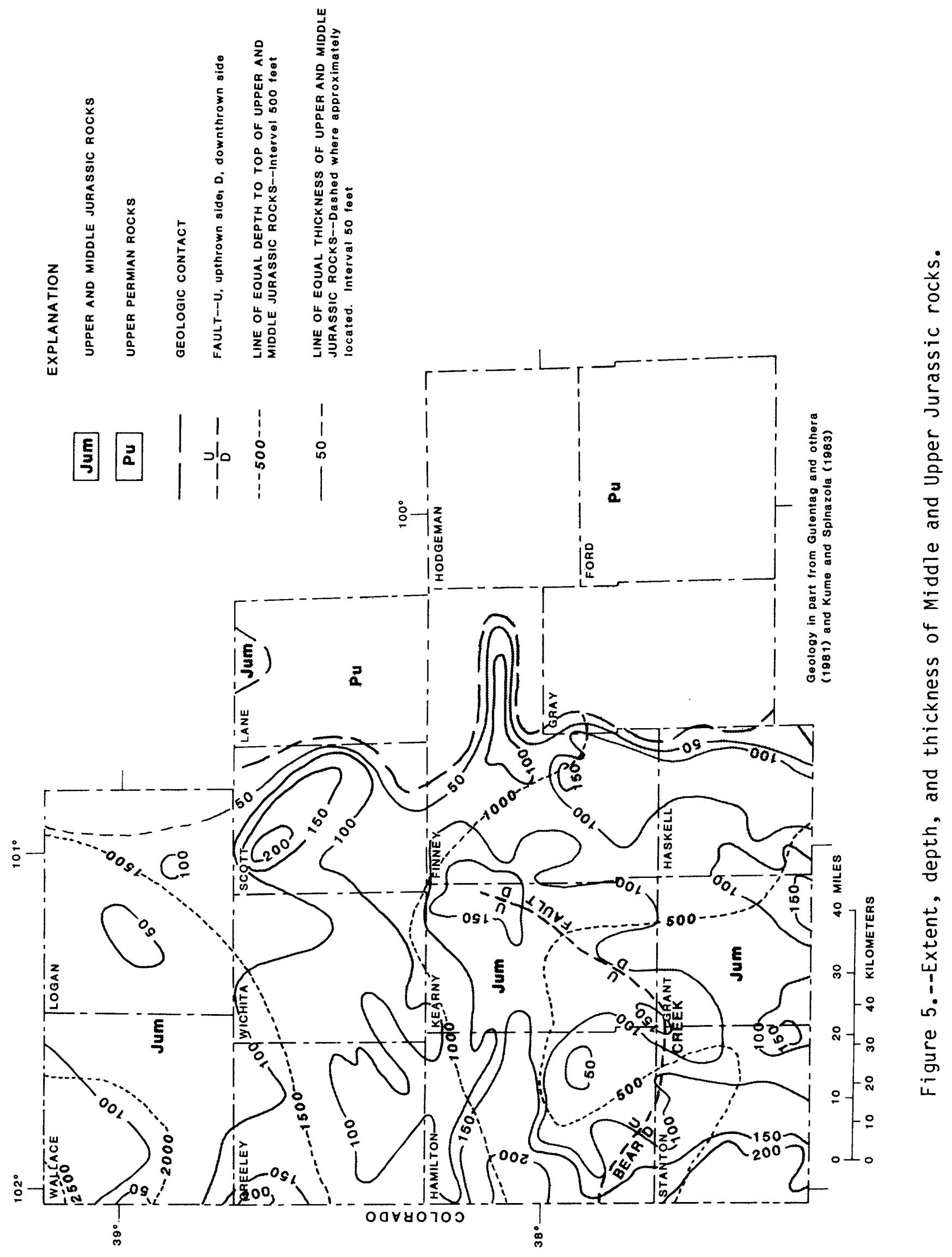



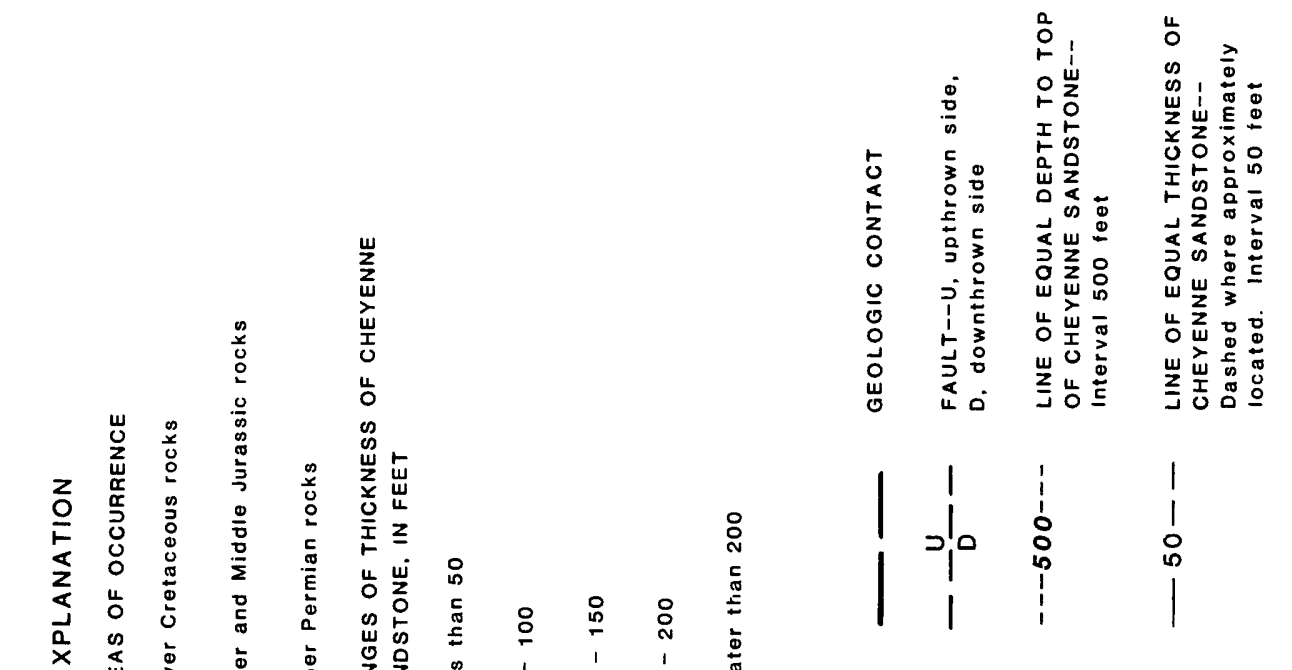

กับ
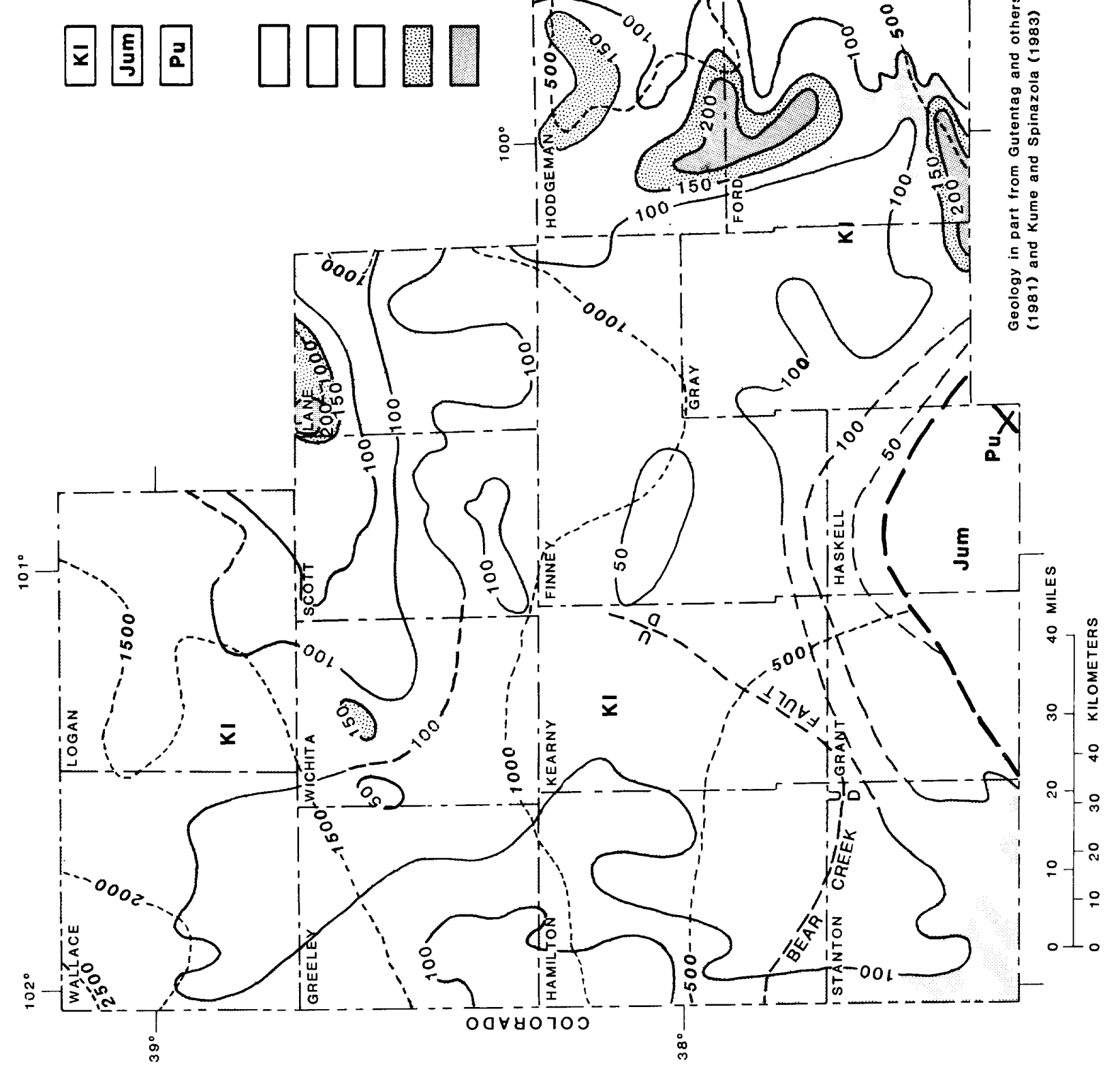
depths ranging from about $200 \mathrm{ft}$ in the southwest corner of Stanton County to more than $2,500 \mathrm{ft}$ in northwest Wallace County. The rocks range in thickness from about zero at the southern limit of the formation to more than $200 \mathrm{ft}$ in Ford, Gray, Hodgeman, and Lane Counties.

The Kiowa Formation is a light-gray to black marine shale, with some interbedded siltstone, sandstone, and limestone. Kiowa rocks underlie the entire study area, except for the southern parts of Grant and Haskell Counties and the southwest corner of Gray County. The formation occurs in the subsurface at depths ranging from about $180 \mathrm{ft}$ in Ford and Hodgeman Counties to more than $1,800 \mathrm{ft}$ in Wallace County. The rocks range in thickness from about zero at the southern limit of the formation to about 190 ft in Hodgeman County.

The Dakota Formation consists of fine- to medium-grained, white, gray, or brown sandstone, interbedded with varicolored shale and siltstone that may contain lignite. Dakota rocks were deposited in marine and nonmarine environments that frequently fluctuated in some shoreline areas from marine to nonmarine (Merriam, 1963). Locally, the Dakota Formation can be divided into three subunits. Generally, a prominant, basal sandstone subunit persists throughout much of the study area. Also present in many places is an upper sandstone and shale subunit. An intervening shale subunit commonly has several interbedded, thin lenticular sandstones. However, in some places, the Dakota cannot be differentiated into separate subunits because the formation is composed mostly of shale.

The areal extent, depth to the top, and thickness of the Dakota Formation are shown in figure 7. The Dakota underlies the entire study area, except for along the south-central area in southern parts of Grant, Haskell, and Stanton Counties and the southwest corner of Gray County. The formation conformably overlies, but in some places may interfinger with, the Kiowa Formation. The Dakota rocks occur at depths ranging from about zero at several isolated outcrops in Ford, Hamilton, Hodgeman, Kearny, and Stanton Counties to more than 2,000 ft in the northwestern corner of Wallace county. The rocks range in thickness from about zero at the southern limit of the formation to about $400 \mathrm{ft}$ in Ford and Lane Counties.

\section{Hydrology \\ Hydrologic Characteristics}

Jurassic Aquifer

The Jurassic aquifer is defined as that part of rocks equivalent to the undifferentiated Entrada Sandstone and Morrison Formation that contains saturated, permeable sandstone and siltstone units. Generally, the basal sandstone unit is the most permeable, but because there is a lack of data, little is known about the general hydraulic characteristics of this basal unit. Other permeable units probably occur throughout the Jurassic rocks.

Hydrologic data were collectd from three deep test wells referred to as Grilliot No. 1, well 21-40W-17CAD; Burnett No. 1, well 23-39W-29DDD; and Williamson No. 1, well 22-35W-4DCC. Gamma-ray and neutron borehole 

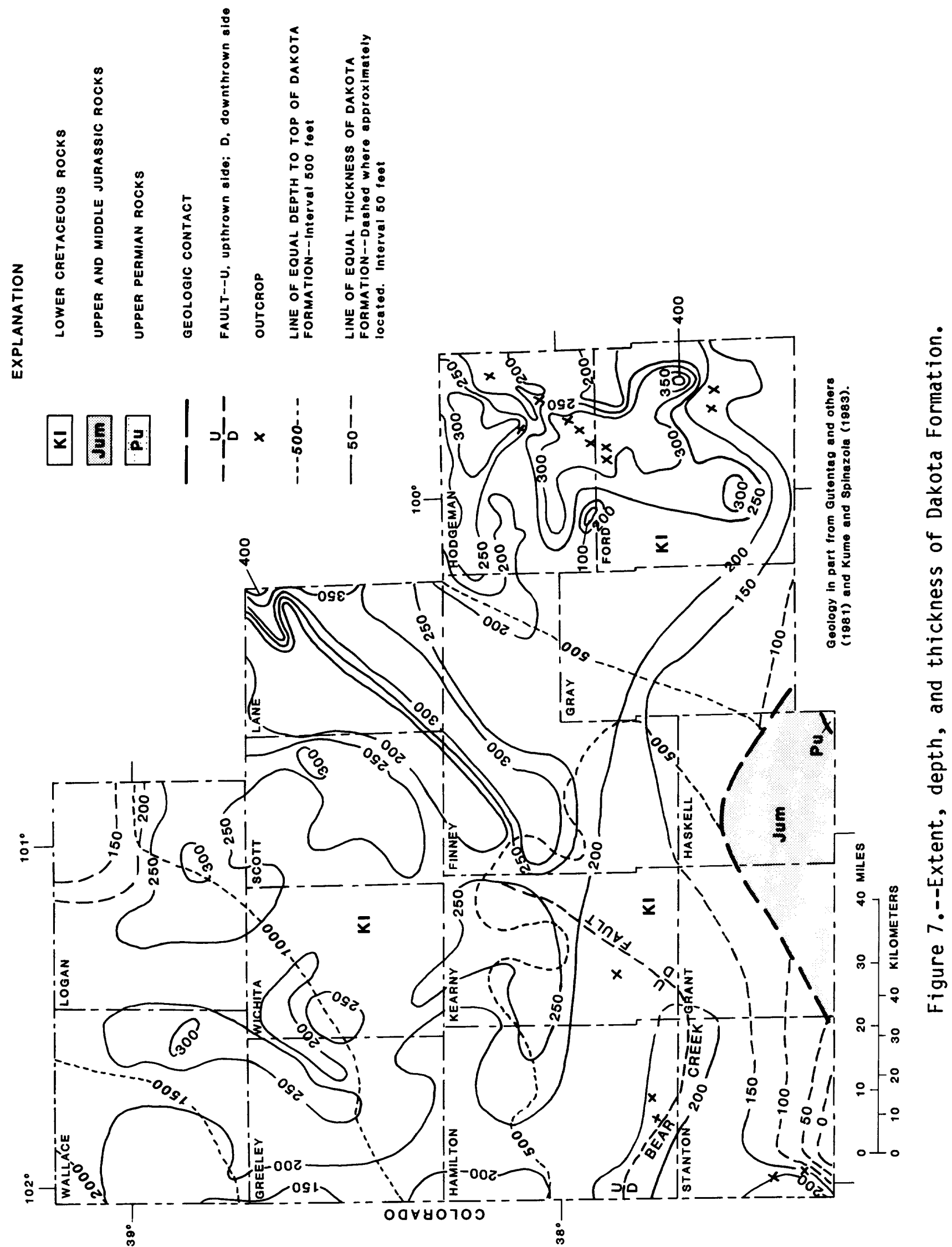
geophysical logs were obtained from these test holes and are shown in figure 8 .

The physical character of the rocks was determined by a composite interpretation of the direction and magnitude of $10 \mathrm{~g}$ deflection. Generally, the natural-gamma-radiation count rate will increase to the right with increasing clay content (Keys and MacCary, 1971, p. 15). The neutronradiation count rate will increase to the right with decreasing porosity but will decrease to the right with increasing saturated porosity. Shale and clay tend to have significant total porosity. The logs were used to make the formation correlations shown in figure 8 and to pick a permeable unit that was perforated and tested.

A summary of data from three test wells for the undifferentiated Jurassic rocks is given in table 2. The data include the depths to the top and bottom of undifferentiated Jurassic rocks; the tops and bottoms of the perforated casing intervals and the water levels; dates of water-sample collections; porosity of the perforated units; pressure heads; and static heads. The total depths of the test holes are given in figure 8; however, the abandoned oil or gas exploratory wells were much deeper before the wells were plugged. The depths to the bottom of Jurassic rocks were determined from available oil or gas exploratory borehole geophysical logs and from drillers' well logs.

An interpretation of the logs in figure 8 concluded that Jurassic rocks probably are composed mostly of shale with thin interbedded sandstone and siltstone. Jurassic rocks range in thickness from 130 to $178 \mathrm{ft}$ (table 2). The aggregate thickness of sandstone ranges from about 34 to $40 \mathrm{ft}$. Sandstone units in the lower part of the Jurassic rocks were perforated and tested in the three test wells (fig. 8). Sand was recovered during the well development in the Jurassic aquifer in the Burnett No. 1 well. This sand was the only lithologic observation of Jurassic rocks made during the testing of the three wells. The loose sand was white to lightbuff and fine- to medium-grained.

The effective saturated thickness of the Jurassic aquifer probably is equivalent to the sum of the permeable sandstone and siltstone units, but it would not include the shale units. However, because of the lack of sufficient hydrologic data to define the Jurassic aquifer in much detail, and for convenience, the saturated thickness and the rock thickness were considered equal for this study. Kume and Spinazola (1983) differentiated the sandstone beds in Jurassic rocks and have reported that the thickness of sandstone beds ranges from about zero in parts of Finney, Kearny, Logan, Scott, and Wallace Counties to about $50 \mathrm{ft}$ in parts of Grant, Hamilton, Kearny, and Stanton Counties.

The altitude of the potentiometric surface of the Jurassic artesian aquifer is shown in figure 9 and is based on static head in the three test wells. These three wells are the only ones available that were completed solely in the Jurassic aquifer. The static head ranged in altitude from about 2,400 ft in northern Hamilton County to about $3,100 \mathrm{ft}$ in central Hamilton County during September-November 1981. The hydraulic gradient is about $40 \mathrm{ft} / \mathrm{mi}$ or 0.0076 toward the north and about $16 \mathrm{ft} / \mathrm{mi}$ or 0.0030 toward the northeast. 


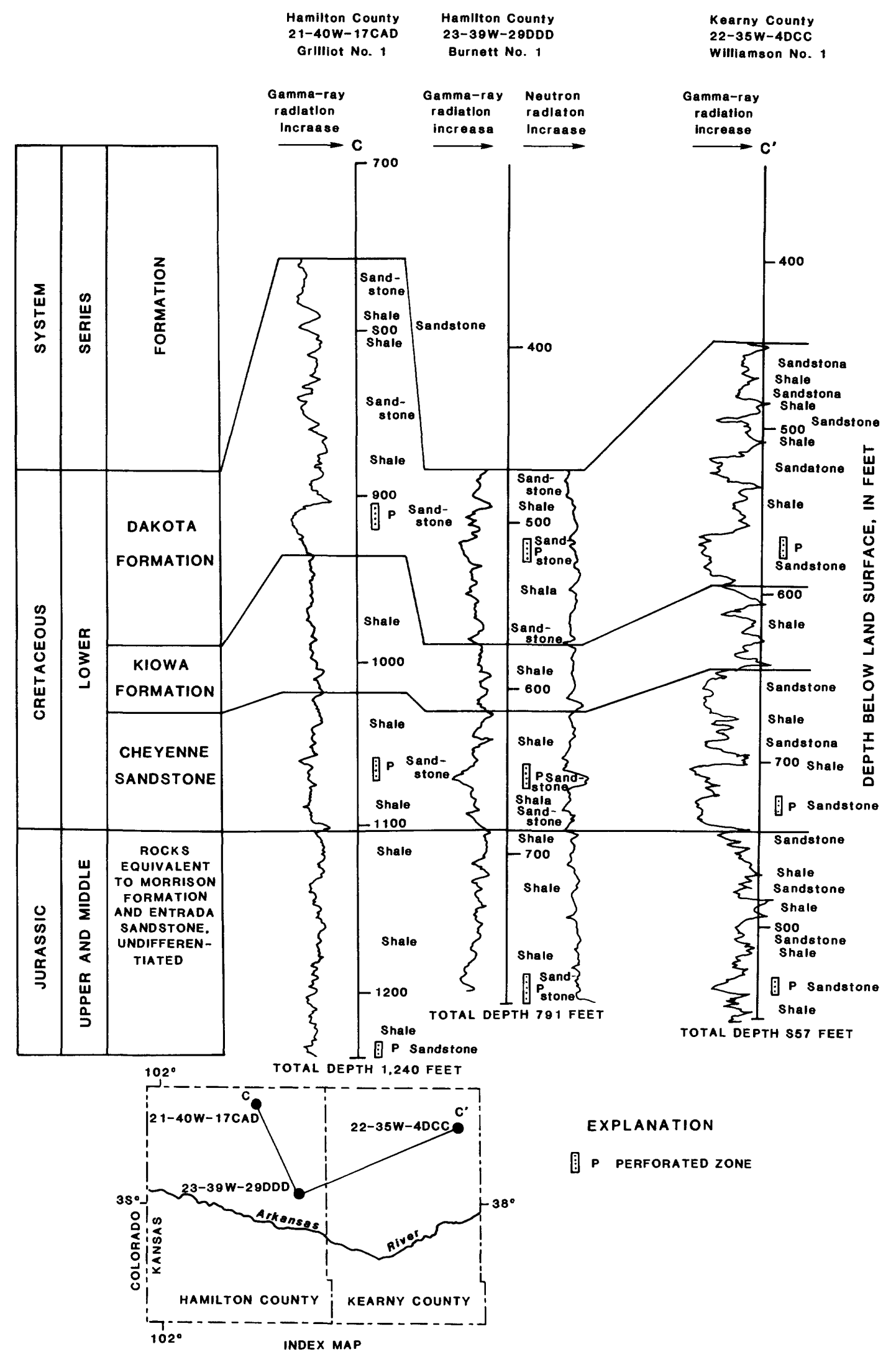

Figure 8.--Geophysical-log correlation of Grilliot, Burnett, and Williamson test wells. 


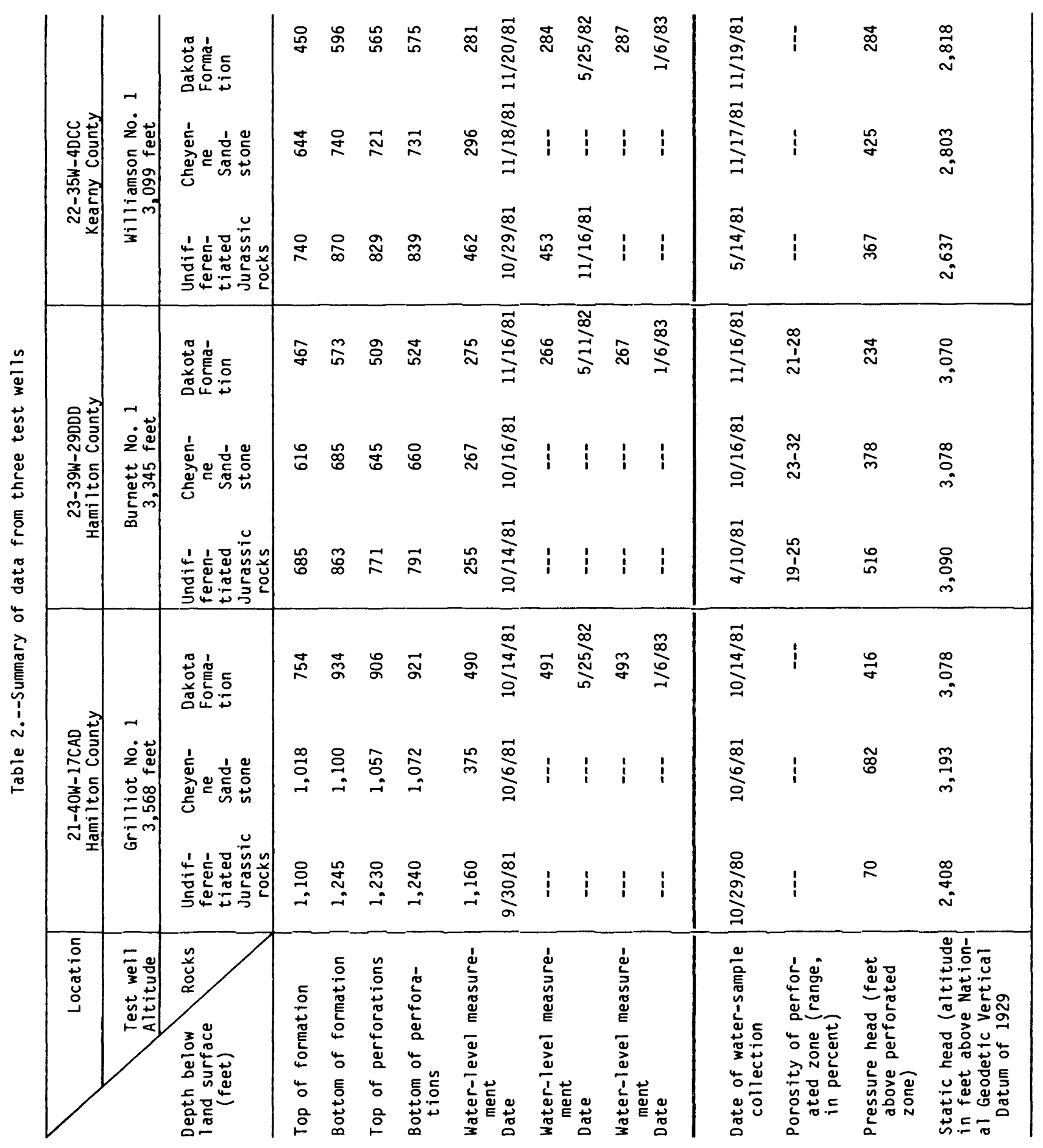




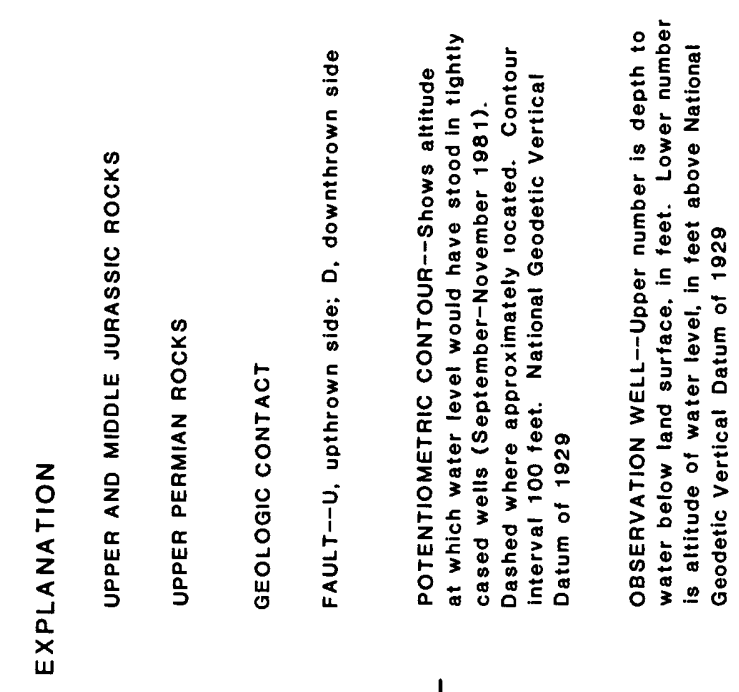

国国 $1 \begin{gathered}1 \\ 3 \\ 3 \\ 1\end{gathered}$

!

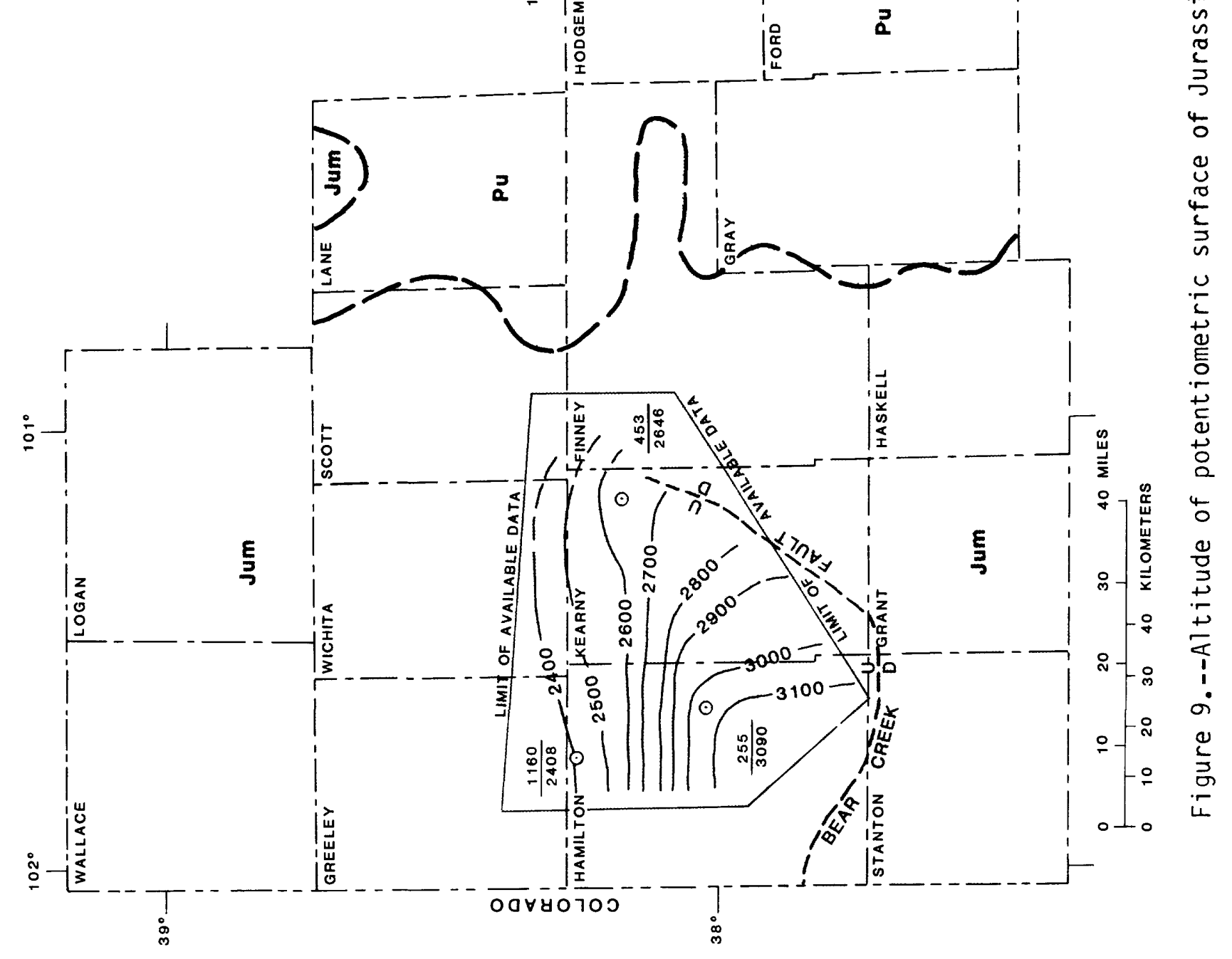


The Cheyenne aquifer is defined as that part of the Cheyenne Sandstone that contains saturated, permeable sandstone units. Generally sandstone units are quite persistent in the study area. However, because of a paucity of available data, little is known about the hydraulic characteristics of these sandstone units.

A composite interpretation of borehole geophysical logs in the three test wells concluded that the Cheyenne Sandstone probably is composed mostly of shale with thin sandstone in Hamilton County and mostly of sandstone with thin shale in Kearny County (fig. 8). In the three test wells, the thickness of the Cheyenne Sandstone ranges from 69 to $96 \mathrm{ft}$ (table 2), but the aggregate thickness of sandstone in the formation ranges from about 14 to $68 \mathrm{ft}$. The sandstone thickness is the effective saturated thickness of the aquifer. Sandstone units in the middle to lower part of the Cheyenne Sandstone were perforated and tested in the three test wells (fig. 8 and table 2). Kume and Spinazola (1983) reported that the sandstone thickness in the Cheyenne Sandstone in the study area ranges from about zero in southeastern Wallace County to about $190 \mathrm{ft}$ in southwestern Hodgeman County.

A summary of data from the three test wells for the Cheyenne aquifer is given in table 2. The data include the depths to the top and bottom of the Cheyenne Sandstone; the top and bottom of the perforated casings and the water levels; the dates of water-sample collections; porosity of the perforated units; pressure heads; and static heads.

The potentiometric surface of the artesian Cheyenne aquifer is shown in figure 10. The surface is based on the static heads measured in four observation wells in the study area and three observation wells in adjacent counties outside the eastern boundary. These wells were the only ones with available data for the Cheyenne aquifer. The altitude of the water level ranged from less than 2,300 ft above the National Geodetic Vertical Datum of 1929 in eastern Ford and Hodgeman Counties to more than 3,200 $\mathrm{ft}$ in Greeley and Hamilton Counties during 1981-82. The hydraulic gradient was toward the east at about $8 \mathrm{ft} / \mathrm{mi}$ or 0.0014 .

The Cheyenne aquifer is overlain and confined by shale of the Kiowa Formation. The kiowa confining unit is not considered to be an aquifer even though in some places sandstone units do occur. The sandstone units generally are very lenticular and comprise only a small proportion of the confining unit. Water probably occurs in these sandstones.

\section{Dakota Aquifer}

The Dakota aquifer is defined as that part of the Dakota Formation that generally contains saturated, permeable sandstone units. A basal unit and an upper sandstone unit of the Dakota Formation generally are the most significant permeable units in the study area. 0ther sandstone units also may occur in the remainder of the formation. The Dakota is an artesian aquifer. Large-capacity wells commonly yield from about 150 to 1,200 gal/min (Dealy and others, 1984). Lobmeyer and Weakly (1979) reported maximum yields of up to $2,200 \mathrm{gal} / \mathrm{min}$ in Ford County. 

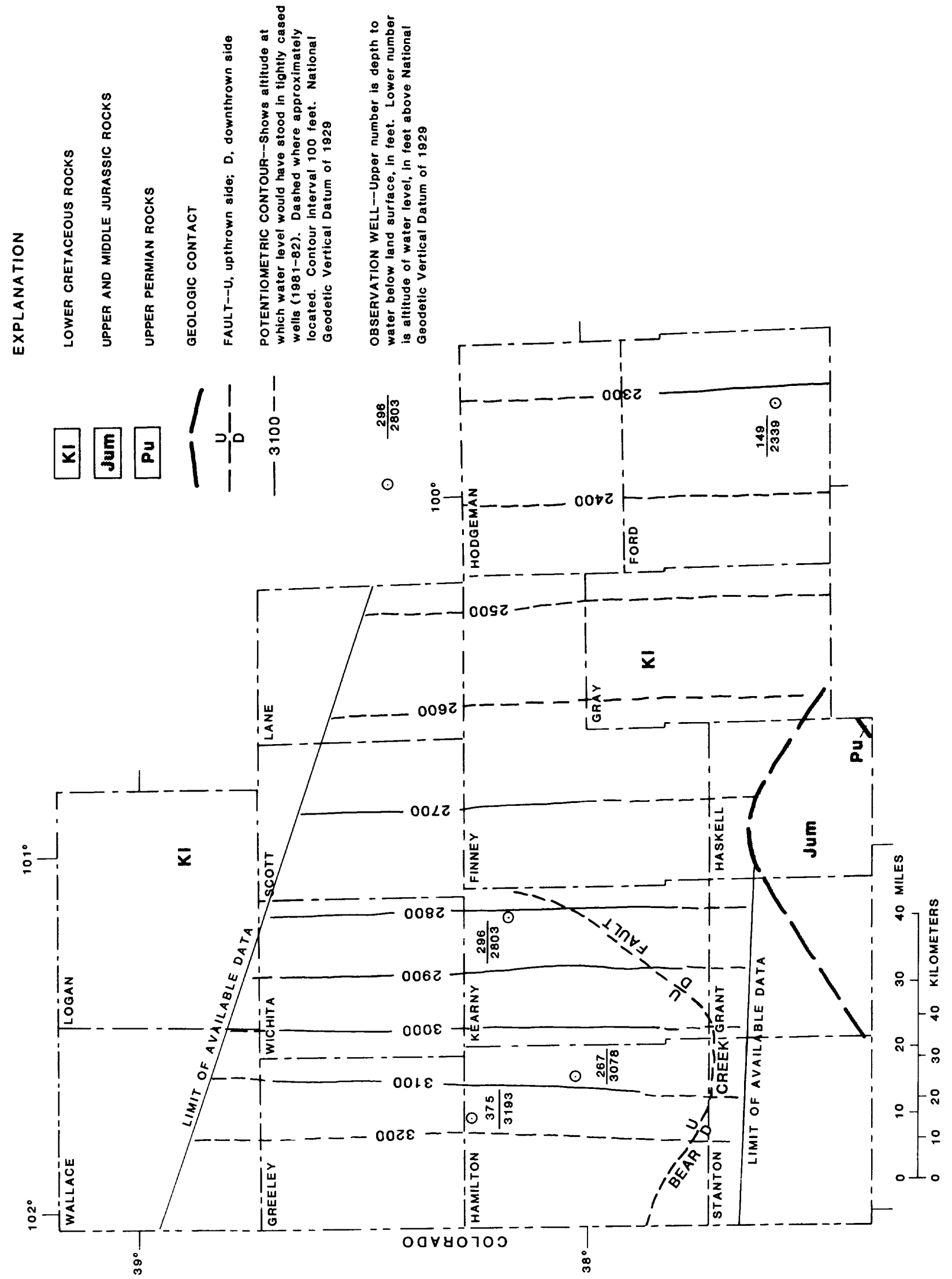

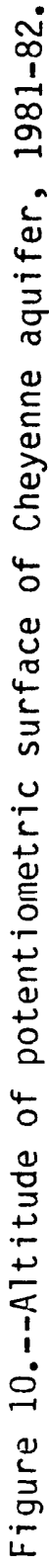


A composite interpretation of borehole geophysical logs of three test wells concluded that the Dakota Formation is composed of interbedded sandstone and shale in Hamilton and Kearny Counties (fig. 8). Two prominent sandstone units, each about 30-ft thick, occur in the lower and upper parts of the formation in the Grilliot No. 1 well, 21-40W-17CAD. One prominent sandstone unit about 25-ft thick and four other sandstone units ranging from 6 to $16 \mathrm{ft}$ in thickness occur in the Williamson No. 1 well, 22-35W-4DCC. The amount of sandstone in the formation in the three test wells ranges from about 42 to $80 \mathrm{ft}$. The sandstone thickness is also the effective saturated thickness of the aquifer. Sandstone units in the middle to lower parts of the formation were perforated and tested in the three test wells (fig. 8 and table 2). Kume and Spinazola (1983) reported that the sandstone thickness in the Dakota Formation in the study area ranges from about zero in northeastern Kearny County to about $150 \mathrm{ft}$ in west-central Hodgeman County.

A summary of data from three test wells for the Dakota aquifer is given in table 2. The data include the depths to the top and bottom of the Dakota Formation; top and bottom of the perforated casings and water levels; dates of water-sample collections; porosity of the perforated units; pressure heads; and static heads.

A summary of 12 selected aquifer tests in the Dakota aquifer are presented in table 3 (Dealy and others, 1984). The aquifer tests were conducted by the Southwest Kansas Groundwater Management District No. 3, Lobmeyer and Weakly (1979), and Burns and McDonnell, Inc. (1977) in Finney, Ford, Gray, Hodgeman, and Kearny Counties. The data included in table 3 are the date of test, depth of well and to water, sandstone thickness, average well yield, drawdown, duration of test, altitude of land surface, specific capacity, transmissivity, hydraulic conductivity, and storage coefficient.

Burns and McDonnel1, Inc. (1977) reported that the majority of the water produced during a constant discharge test at well 24-33W-19DBD came from a basal sandstone unit of the Dakota aquifer at depths ranging from 610 to $699 \mathrm{ft}$. Their conclusion was based on a water-velocity survey that was conducted in the well by the use of a spinner meter.

The altitude of the potentiometric surface of the Dakota aquifer is shown in figure 11. The surface ranged in altitude from about $2,100 \mathrm{ft}$ above the National Geodetic Vertical Datum of 1929 in northeastern Hodgeman County to about $3,200 \mathrm{ft}$ in western Hamilton and Stanton Counties during March-May 1982. Depth to water in wells ranged from 24 to $604 \mathrm{ft}$. The hydraulic gradient was toward the east and northeast at about $11 \mathrm{ft} / \mathrm{mi}$ or 0.0020 .

Fluctuations of water levels in five selected wells completed in the Dakota aquifer are shown in hydrographs in figure 12. Water-level records are available for three of the wells for 1972-82. In Finney County, in irrigation well 22-27W-14ADC, the water level ranged in altitude from about 2,265 to 2,305 ft above the National Geodetic Vertical Datum of 1929 during 1972-82 and declined about $28 \mathrm{ft}$. The water-level decline probably was caused by the withdrawal of water for irrigation. 


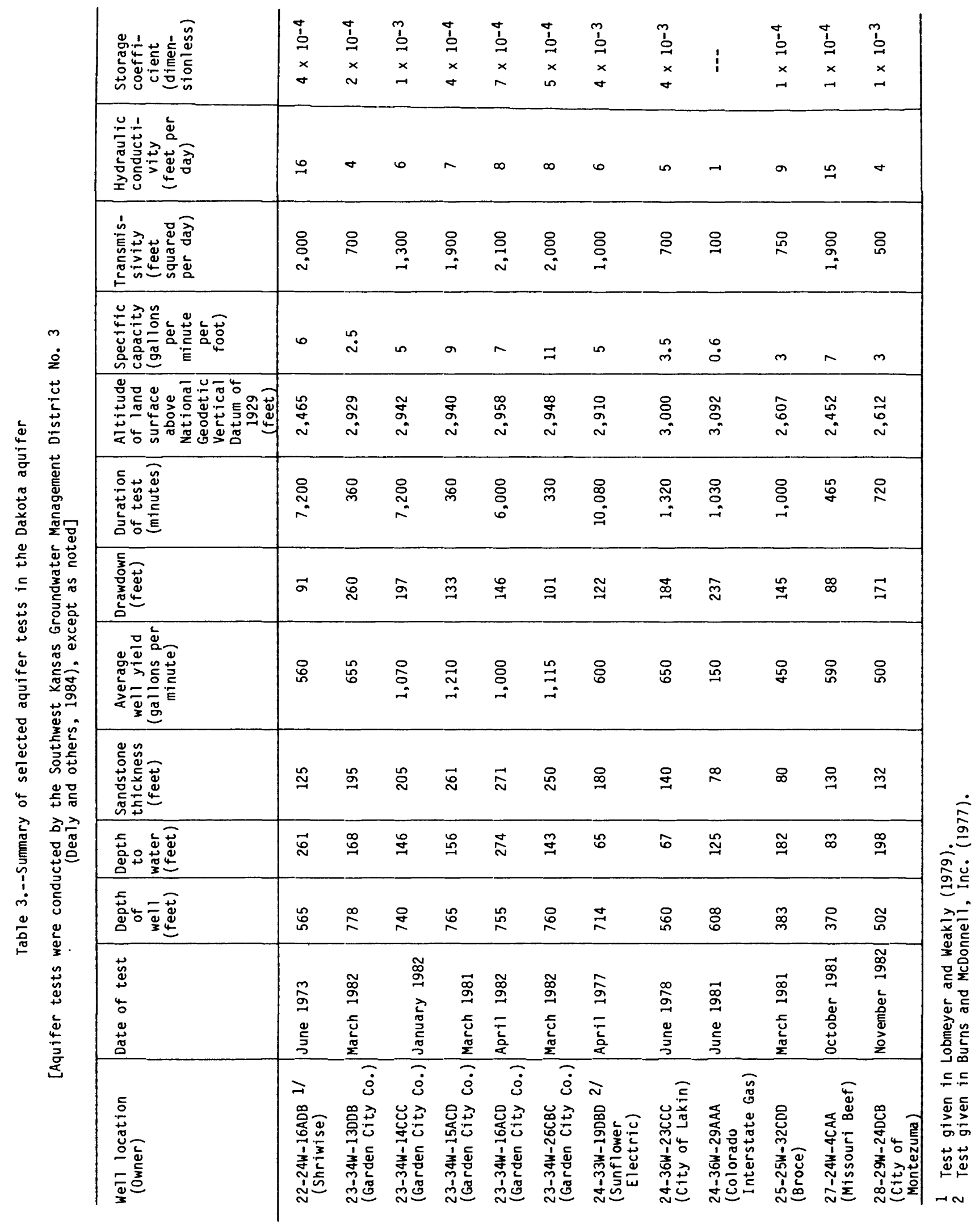



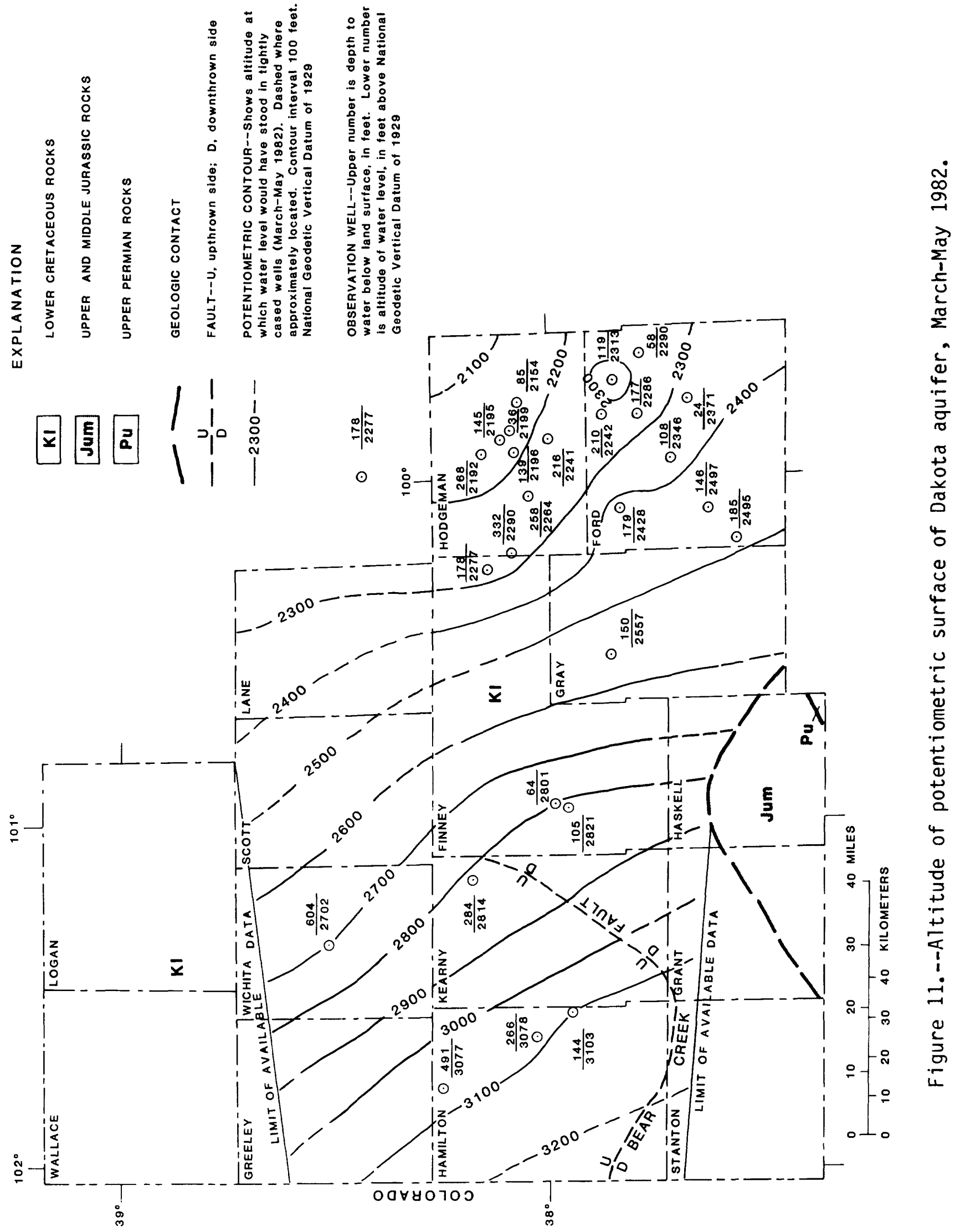

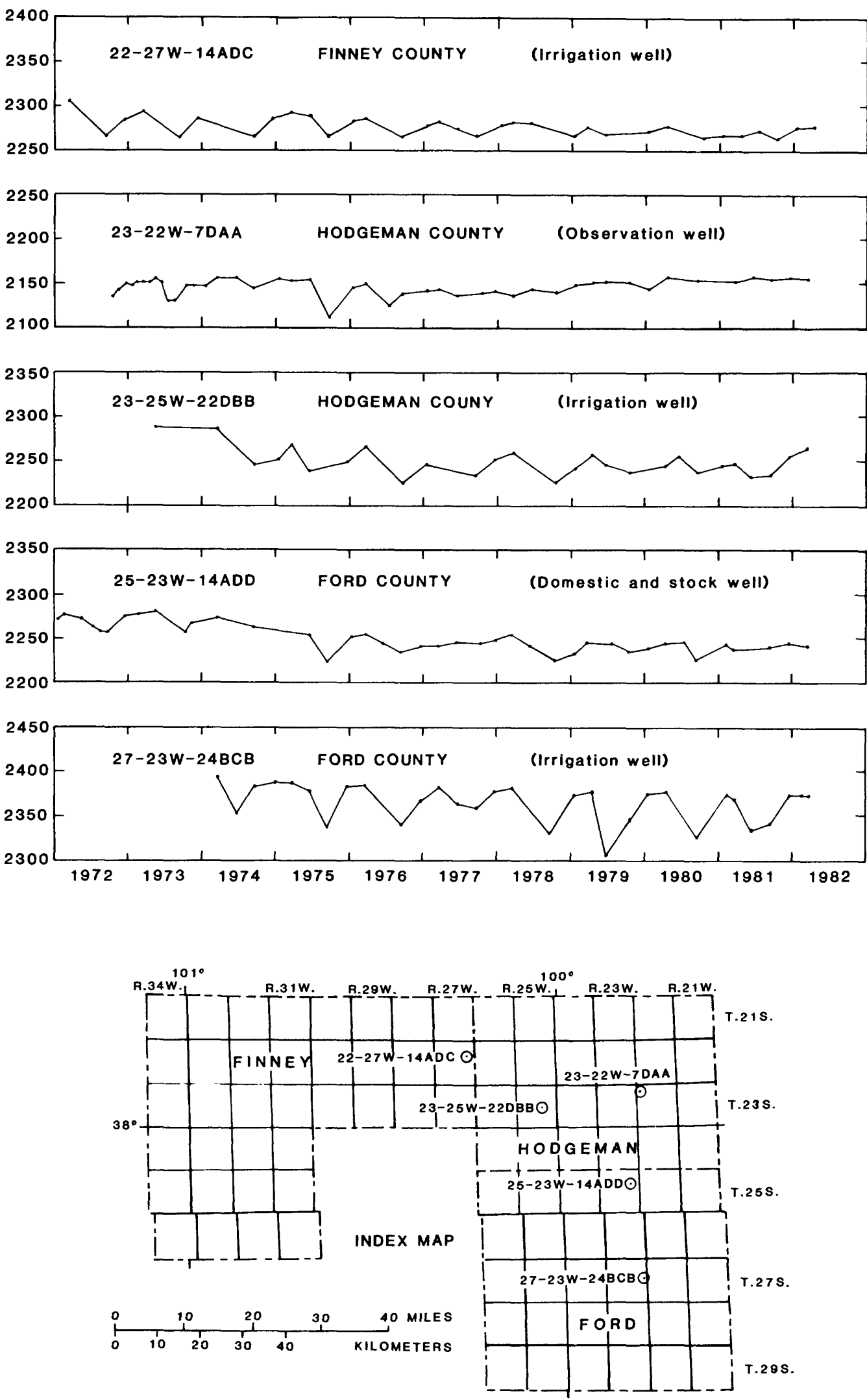

Figure 12.--Fluctuations of water levels in selected wells completed in Dakota aquifer, 1972-82. 
In Hodgeman County, in observation well 23-22W-7DAA, the water level rose about $22 \mathrm{ft}$ during 1972-82, whereas in irrigation well 23-25W-22DBB the water level declined about $24 \mathrm{ft}$ during 1973-82. The rise in the water level in well 23-22W-7DAA, which is located in an area of Dakota Formation outcrop, may have been caused by local recharge from precipitation. The water-level decline in well 23-25W-22DBB probably was caused by the withdrawal of water for irrigation. The water levels ranged in altitude from 2,111 to 2,289 ft above the National Geodetic Vertical Datum of 1929 in the Hodgeman County wells.

In Ford County, in domestic and stock well 25-23W-14ADD, the water level declined about $30 \mathrm{ft}$ during 1972-82. In irrigation well 27-23W-24BCB, the water level declined about $22 \mathrm{ft}$ during 1974-82. The water-level declines probably were caused by the withdrawal of water for irrigation. The water level ranged in altitude from about 2,225 to $2,394 \mathrm{ft}$ above the National Geodetic Vertical Datum of 1929 in the Ford County wells.

Interrelationship of Jurassic, Cheyenne, and Dakota Aquifers

A comparison of the altitudes of water levels (1981-82) in the three test wells constructed during this study in the Jurassic, Cheyenne, and Dakota aquifers is shown in figure 13. The altitudes of the water levels in the three aquifers penetrated by well 23-39W-29DDD were very similar. The altitudes of the water levels in the Cheyenne and Dakota aquifers penetrated by well 22-35W-4DCC were almost equal. There was little difference in the altitudes of the water levels in the Cheyenne and Dakota aquifers penetrated by well 23-39W-29DDD, but the altitudes of the water level in the Cheyenne aquifer penetrated by well 21-40W-17CAD was a little higher than the altitude of the water level in the Dakota aquifer. The altitudes of the water levels in the Dakota aquifer penetrated by wells 21-40W-17CAD and 23-39W-29DDD were quite similar. There were rather significant waterlevel differences in the Jurassic aquifer compared to the other aquifers in wells 21-40W-17CAD and 22-35W-4DCC.

The similarities in the altitudes of water levels in wells at the same location but in different aquifers may be coincidental or might indicate a local, natural hydraulic connection between aquifers. Another possibility might be the result of an inadequate grouted casing that would allow fluids to migrate between aquifers through channels in the grouted annulus. However, this does not seem to be the case as the quality of water, discussed in the next section of the report, does not support a common chemical composition of water for any of the different aquifers. If the waters were mixed, the effects should show in the chemistry of the waters involved. The dissimilarities in the altitudes of the water levels in wells at the same location but in different aquifers probably would indicate that the aquifers are separated and are not hydraulically connected. 

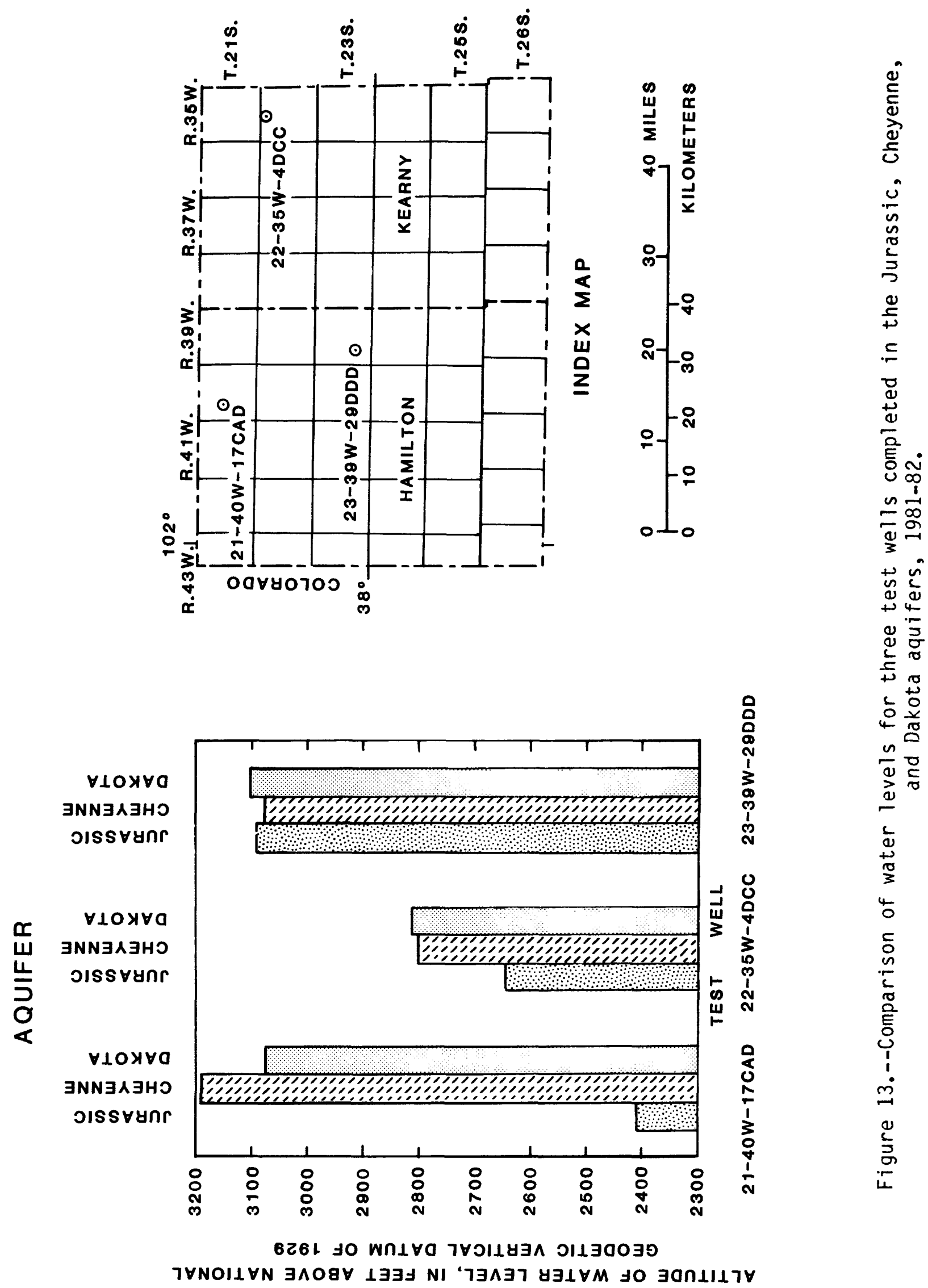
A comparison of fluctuations in the altitude of water levels (1980-82) in observation wells 24-33W-9CCD and 24-33W-9CCD 3 completed in the High Plains (Miocene age) and Dakota aquifers, respectively, is shown in figure 14. During most of the period, the water levels in the Dakota well were higher than the water levels in the High Plains well. However, during three short intervals, the water levels in the Dakota well were lower than the water levels in the High Plains well. Water-level fluctuations in the High Plains well were much larger than the water-level fluctuations in the Dakota well because of the greater irrigation-well pumpage from the High Plains aquifer. The water-level fluctuations in the Dakota well also were caused by pumpage but only from a few large-capacity Dakota wells and by damped reflections of pressure transmissions from High Plains pumpage. In the water-level hydrographs, the valleys represent drawdown from pumpage, and the peaks represent water-level recovery while the pumps were not operating.

The Jurassic, Cheyenne, and Dakota aquifers are in direct contact and are hydraulically connected with the High Plains aquifer in places along most of the southern boundaries of the Upper and Lower Cretaceous rocks. A hydraulic connection generally occurs where Upper Cretaceous shales do not overlie and confine Lower Cretaceous rocks and where Lower Cretaceous shales do not overlie and confine Jurassic rocks. As a result of this hydraulic connection, significant freshwater has leaked vertically downward from the High Plains aquifer. However, this condition now may be reversing, and water may be leaking upward from the Dakota aquifer into the High Plains aquifer because of declining static heads in the High Plains aquifer. Pabst (1982, p. 30) reported a water-level decline of about $57 \mathrm{ft}$ for well 24-33W-9CCD completed in the High Plains aquifer (fig. 13) during 1940-82. In the past, the static head in well 24-33W-9CCD was higher than the static head in well 24-33W-9CCD3 completed in the Dakota aquifer, but recently the former conditions have been reversed. The static head in the High Plains aquifer is now lower than the static head in the Dakota aquifer most of the time.

\section{GROUND-WATER DEVELOPMENT}

The development of ground-water resources of the Jurassic, Cheyenne, and Dakota aquifers has been for domestic, stock, irrigation, public-supply, and industrial uses. The water resources of the Jurassic aquifer have had very little development. Several large-capacity (yielding more than 100 gal/min) irrigation wells have been drilled in Stanton, Grant, and southern Hamilton and Kearny Counties. However, these irrigation wells have been completed in multiple aquifers that include the Jurassic, Cheyenne, Dakota, and High Plains aquifers.

The water resources of the Cheyenne aquifer also have had very little development. Some large-capacity irrigation wells tht have been completed in multiple aquifers, including the Cheyenne aquifer, have been drilled in Stanton, Grant, and southern Hamilton and Kearny Counties. Small-capacity (yielding as much as $100 \mathrm{gal} / \mathrm{min}$ ) domestic and stock wells have been completed in the Cheyenne aquifer in Hamilton County. 


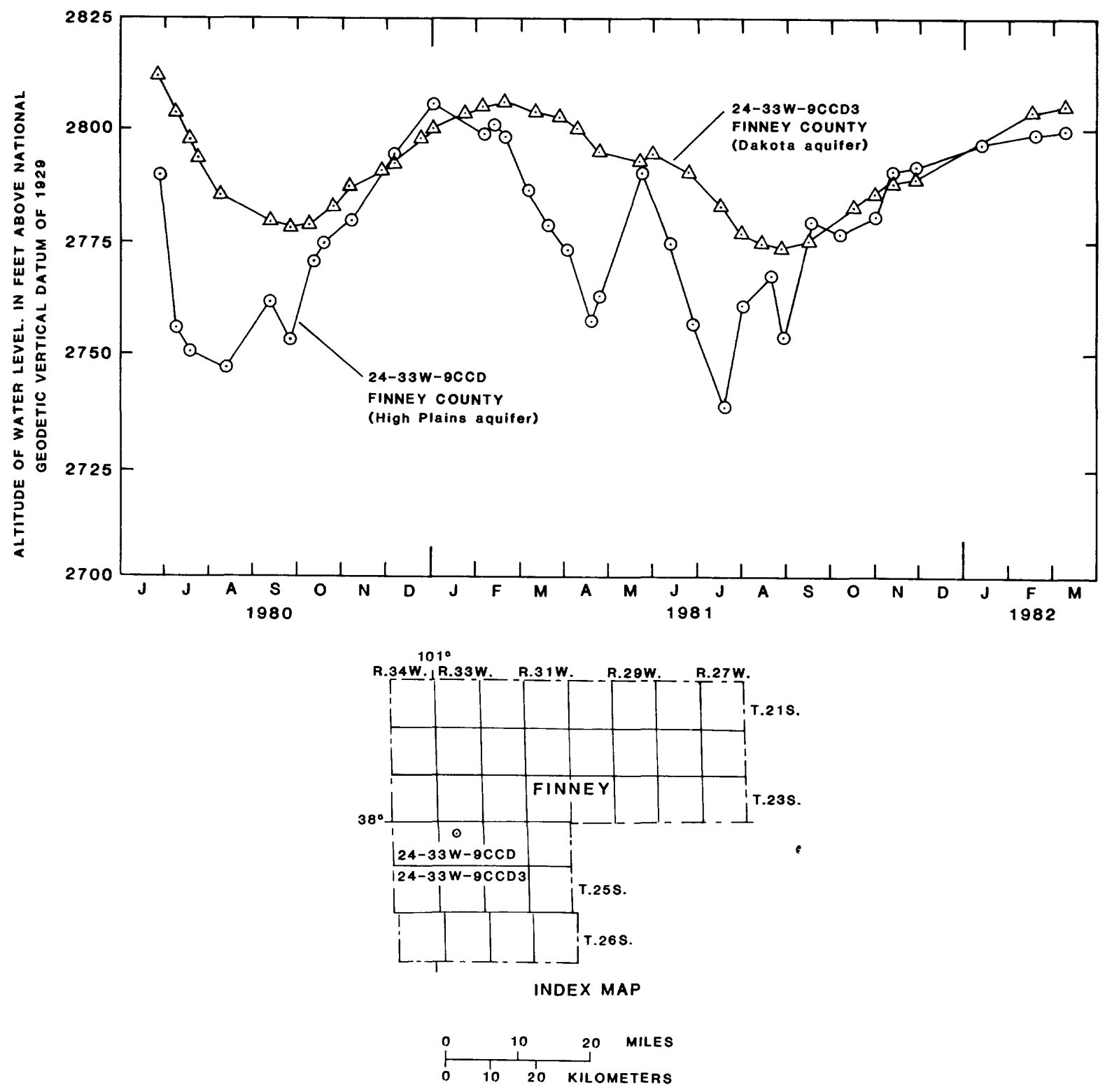

Figure 14.--Comparison of fluctuations in water levels for wells completed in the High Plains or Dakota aquifers, 1980-82.

The water resources of the Dakota aquifer have had significant well development, but in many localities, the wells are widely spaced so that the aquifer is still considered to be underdeveloped. Large-capacity irrigation, public-supply, and industrial well development mainly has occurred in the vicinity of Dodge City, Holcomb, Jetmore, Johnson, Lakin, Montezuma, Spearville, Syracuse, and Ulysses. Numerous small-capacity domestic and stock wells have been completed in the Dakota aquifer in every county in the study area.

The total number of wells in the study area completed in the Dakota aquifer has not been established yet because the well records for numerous bedrock wells, of which many probably are completed in the Dakota aquifer, do not indicate the aquifer that all the wells are completed in. However, probably most of the Dakota wells have been identified. In Hodgeman and 
Ford Counties, Lobmeyer and Weakly (1979) reported that a total of 62 largecapacity irrigation, public-supply, and feedlot wells were completed in the Dakota aquifer between 1963-73. Dealy and others (1984) reported that two large-capacity irrigation and industrial wells were completed in the Dakota aquifer during 1981 in Ford County. In Finney County, Dealy and others (1984) reported that eight large-capacity irrigation, industrial, and municipal wells were completed in the Dakota aquifer between 1977-82. In Grant and Wichita Counties, Kume and Spinazola (1983) reported that several largecapacity irrigation wells were completed in the Dakota aquifer. In Gray County, Dealy and others (1984) reported that a large-capacity municipal well was completed in the Dakota aquifer at Montezuma during 1982.

\section{CHEMICAL QUALITY OF WATER}

The results of chemical analyses of water collected during this study from the Jurassic, Cheyenne, and Dakota aquifers are listed in table 4. The water samples were collected in Finney, Ford, Gray, Hamilton, and Kearny Counties. Water samples were collected from 3 wells completed in the Jurassic aquifer, 5 wells completed in the Cheyenne aquifer, and 24 wells completed in the Dakota aquifer. Multiple samples were collected and analyzed from selected wells at several localities. The chemical analyses were made by the Kansas Department of Health and Environment and the U.S. Geological Survey.

The procedures for sample collection, sample preparation and pretreatment, and the methods of determination of inorganic substances in water are described by Brown and others (1970), Wood (1976), and Skougstad and others (1979). The water samples were collected by bailing the test wells with a bailer that had a capacity of about 30 gal. Care was taken to insure a fresh and uncontaminated sample of water from the aquifer. All of the water in the casing was bailed out before the casing was perforated. After the casing was perforated, the freshly produced water was bailed for several hours until a stable specific-conductance reading was obtained. Then, a water sample was collected. The sample was filtered, acidified, and chilled at the sample site. The sample was sent to the laboratory under chilled conditions. The water temperature, $\mathrm{pH}$, and specific conductance were measured at the time of sample collection.

The values of $\mathrm{pH}$ for samples collected from the three test holes completed in the Jurassic aquifer are questionable and are not listed in table 4. The questionable values of $\mathrm{pH}$ ranged from 9.5 to 11.3 and appeared to be much larger than expected. Values of $\mathrm{pH}$ greater than 9.5 generally indicate the presence of hydroxide, which can be derived from industrial pollution or from cement (A. M. Diaz, U.S. Geological Survey, written commun., 1983). Because the well casing was plugged on the inside with cement and grouted on the outside with cement, it is likely that the water was contaminated by this cement. The contamination could have occurred, in part, when the plugs were removed by drilling and while the casing was perforated, or at the time the well was being bailed. Because there probably was some residual cement along the casing wall that was not removed, this cement could have contaminated the water that was being bailed. 
Table 4.--Results of chemical analyses of water from the Jurassic, Cheyenne, and Dakota aquifers [Analyses by Kansas Department of Health and Environment, except as noted.

Values are given in milligrams per liter (mg/L), except as noted]

\begin{tabular}{|c|c|c|c|c|c|c|c|c|c|c|c|c|c|}
\hline \multirow[t]{2}{*}{ Well location } & \multirow{2}{*}{$\begin{array}{l}\text { Date of } \\
\text { collection }\end{array}$} & \multirow{2}{*}{$\begin{array}{l}\text { Sample } \\
\text { depth } \\
\text { (feet) }\end{array}$} & \multirow{2}{*}{$\begin{array}{l}\text { Specific } \\
\text { conduct- } \\
\text { ance } \\
\text { (micro- } \\
\text { mhos) } 1 /\end{array}$} & \multirow{2}{*}{$\begin{array}{c}\mathrm{pH} \\
\text { (stan- } \\
\text { dard } \\
\text { units) }\end{array}$} & \multirow{2}{*}{$\begin{array}{l}\text { Tem- } \\
\text { per- } \\
\text { ature } \\
\left({ }^{\circ} \mathrm{C}\right) 2\end{array}$} & \multicolumn{2}{|c|}{ Hardness } & \multirow{2}{*}{$\begin{array}{l}\text { Dis- } \\
\text { solved } \\
\text { calcium } \\
\text { (Ca) }\end{array}$} & \multirow{2}{*}{$\begin{array}{l}\text { Dis- } \\
\text { solved } \\
\text { magne- } \\
\text { sium } \\
(\mathrm{Mg})\end{array}$} & \multirow{2}{*}{$\begin{array}{l}\text { Dis- } \\
\text { solved } \\
\text { sodium } \\
\text { (Na) }\end{array}$} & \multirow{2}{*}{$\begin{array}{l}\text { Sodium- } \\
\text { adsorp- } \\
\text { tion- } \\
\text { ratio } \\
\text { (SAR) }\end{array}$} & \multirow{2}{*}{$\begin{array}{l}\text { Dis- } \\
\text { solved } \\
\text { potas- } \\
\text { sium } \\
(\mathrm{K})\end{array}$} & \multirow{2}{*}{$\begin{array}{l}\text { Potas- } \\
\text { si um } \\
40 \\
(\mathrm{~K} 40) \\
(\mathrm{pCi} / \mathrm{L}) 3 /\end{array}$} \\
\hline & & & & & & $\begin{array}{c}\mathrm{as} \\
\mathrm{CaCO}_{3} \\
\text { (total) }\end{array}$ & $\begin{array}{l}\text { Cnon- } \\
\text { car- } \\
\text { bonate }\end{array}$ & & & & & & \\
\hline
\end{tabular}

JURASSIC AQUIFER

Hamilton County

\begin{tabular}{|c|c|c|c|c|c|c|c|c|c|c|c|c|c|}
\hline $\begin{array}{l}21-40 \mathrm{~W}-17 \mathrm{CAD} \\
21-40 \mathrm{~W}-17 \mathrm{CAD} 5 \\
23-39 \mathrm{~W}-290 D D \\
23-39 \mathrm{~W}-2900 D 5\end{array}$ & $\begin{array}{r}10-29-80 \\
10-29-80 \\
4-10-81 \\
4-10-81\end{array}$ & $\begin{array}{r}1,240 \\
1,240 \\
794 \\
794\end{array}$ & $\begin{array}{l}5,200 \\
5,200 \\
9,000 \\
9,000\end{array}$ & $\begin{array}{l}-- \\
-- \\
--\end{array}$ & $\begin{array}{l}26.5 \\
26.5 \\
20.5 \\
20.5\end{array}$ & $\begin{array}{r}1,600 \\
1,500 \\
520 \\
530\end{array}$ & $\begin{array}{l}-- \\
-- \\
--\end{array}$ & $\begin{array}{l}540 \\
490 \\
210 \\
210\end{array}$ & $\begin{array}{c}54 \\
58 \\
0 \\
2.8\end{array}$ & $\begin{array}{r}680 \\
710 \\
1,700 \\
1,600\end{array}$ & $\begin{array}{l}7.5 \\
8.1 \\
32 \\
30\end{array}$ & $\begin{array}{l}19 \\
22 \\
33 \\
34\end{array}$ & $\begin{array}{l}-\overline{16} \\
\overline{25}\end{array}$ \\
\hline \multicolumn{14}{|l|}{ Kearny County } \\
\hline $\begin{array}{l}22-35 W-4 D C C \\
22-35 W-4 D C C=5 /\end{array}$ & $\begin{array}{l}5-14-81 \\
5-14-81\end{array}$ & $\begin{array}{l}860 \\
860\end{array}$ & $\begin{array}{l}6,700 \\
9,300\end{array}$ & -- & $\begin{array}{l}19.5 \\
21.0\end{array}$ & $\begin{array}{r}530 \\
1,100\end{array}$ & -- & $\begin{array}{r}180 \\
--\end{array}$ & $\begin{array}{l}19 \\
25\end{array}$ & $\begin{array}{l}1,200 \\
1,900\end{array}$ & $\begin{array}{l}23 \\
26\end{array}$ & ${ }^{37} .1$ & -1 \\
\hline
\end{tabular}

Hamilton County

21-40W-17CAD5/

$21-40 \mathrm{~W}-28 \mathrm{DCC}$

21-41W-2BBB

23-39W-29DDD 5

$10-6-81 \quad 1,072 \quad 17,500$

9- 4-80 1,080

8-13-80 1,025 800

$\begin{array}{lr}10-16-81 & 660 \quad 5,000\end{array}$

$\begin{array}{ll}-- & 18.4 \\ 8.5 & 25.0\end{array}$

8.325 .5

Kearny County

$22-35 w-4 D C C$

$22-35 W-4 D C C 5 /$

$11-17-81 \quad 721 \quad 670$

-. $\quad 17.5$

$\begin{array}{rr}220 & -- \\ 12 & 0 \\ 8 & 0 \\ 260 & --\end{array}$

$\begin{array}{ccrr}23 & 40 & 4,900 & 143 \\ 3.2 & 1.0 & 180 & 23 \\ 3.2 & 0 & 170 & 26 \\ 44 & 36 & 1,300 & 35\end{array}$

$\begin{array}{cc}41 & -- \\ 3.0 & -- \\ 4.0 & -- \\ 23 & --\end{array}$

$11-17-81 \quad 721 \quad 670$

$8.5 \quad 19.5$

$65 \quad--$

17

$\begin{array}{ccccc}5.5 & 130 & 6.8 & 6.6 & -- \\ -- & -- & -- & -- & \ldots\end{array}$

DAKOTA AQUIFER

Finney County

$23-34 W-13 D B B$

23-34W-14CCC

$23-34 W-15 A C D$

$23-34 W-16 A C B$

$23-34 W-26 C B C C$

2-23-82

$2-16-82$

$1-25-82 \quad 765$

4- 5-82 755

$1-14-81 \quad 760$

600

610

580

7.119 .0

6.819 .0

$\begin{array}{ll}7.2 & 19.0 \\ 7.4 & 19.0\end{array}$

200

$23-34 W-26 \mathrm{CBCC} 5 /$

1-14-81 760

24-33W-9CCD3

24-33W-19DBDD

7- $7-80$

$760 \quad 580$

$7.5 \quad 19.0$

560
714

$\begin{array}{lll}580 & 7.5 & 19.0\end{array}$

Ford County

$25-25 W-32 C D D$

27-24W-4CAA

383

460

$\begin{array}{ll}8.1 & 17.0 \\ 7.6 & 21.5\end{array}$

8- $9-80 \quad 248$

$6.3 \quad 17.0$

Gray County

28-28W-9DBB

$8-26-81 \quad 462$

440

7.6

16.0

$180 \quad 27$

Hamilton County

$21-40 W-17 C A D$
$21-40 W-17 C A D$

$21-42 \mathrm{~W}-3 \mathrm{CBB}$

21-42W-14DAC

10-14-81

10-14-81

8-13-B0

9- $4-80$

$921 \quad 1,180$

$\begin{array}{rr}921 & 1,180 \\ 840 & 970\end{array}$

8601,150

-- 23.0

$22-41 W-33 D D C$

$11-16-81$

585

$8.8 \quad 17.5$

8.716 .0

22-4 IW-33DDC 5/

$23-39 \mathrm{~W}-290 D D$

11-16-81

$11-16-81$

585

570

$7.6 \quad 19.0$

23-39W-29DDD $5 /$

23-40W-7CCB

$1-16-8$

$524 \quad 2,700$

$524 \quad 2,700$

$7.6 \quad 19.0$
-5

$\begin{array}{ll}7.6 & 19.0 \\ -- & 17.0\end{array}$

$7.3 \quad 19.0$

$\begin{array}{lll}9-15-81 & 420 & 3,800 \\ 3-25-82 & 420 & 2,900\end{array}$

$7.1 \quad 17.0$

23-40W-24BAB $\underline{5}$ /

23-4 1W-13CCD

24-39W-25AAA

24-40W-5CBB

9-15-81

$330 \quad 1,010$

$8.0 \quad 18.0$

8-14-81

$320 \quad 4,300$

9-15-81

415

$3-25-82 \quad 425$

$\begin{array}{lll}820 & 8.2 & 17.0\end{array}$

$\begin{array}{lll}2,550 & 7.2 & 18.0\end{array}$

$\begin{array}{ll}7.2 & 18.0 \\ 7.5 & 18.0\end{array}$

$\begin{array}{rrr}18 & -- & 5 \\ -- & -- & -- \\ 8 & 0 & 3 . \\ 16 & 0 & 3 \\ 64 & -- & 15 \\ & & \\ -- & -- & -- \\ 64 & -- & 25 \\ -- & -- & -- \\ 950 & 650 & 100 \\ 620 & -- & 77 \\ 160 & 0 & 41 \\ 2,000 & 1,600 & 570 \\ 290 & 120 & 69 \\ 700 & -- & 140 \\ 220 & 74 & 63\end{array}$

$\begin{array}{ll}47 & 22 \\ 47 & 24 \\ 50 & 23 \\ 49 & 20 \\ 46 & 22 \\ & \\ 42 & 19 \\ 46 & 19 \\ 40 & 12\end{array}$

$\begin{array}{llll}47 & 1.4 & 5.6 & -- \\ 45 & 1.3 & 5.7 & -- \\ 56 & 1.6 & 4.9 & -- \\ 50 & 1.5 & 5.8 & -- \\ 52 & 1.6 & 6.0 & -- \\ 52 & 1.7 & 5.0 & -- \\ 29 & 0.9 & 4.0 & -- \\ 43 & 1.5 & 3.0 & --\end{array}$

Kearny County

$22-35 W-4 D C C$
$22-35 W-4 D C C 5$

$24-36 \mathrm{~W}-23 C C C$

11-19-81 564

$11-19-81$

$7-23-81$

$564 \quad 630$

$630 \quad--18.0$

560
618

400

$-\overline{7} \quad 18.0$

$\begin{array}{ll}7.1 & 17.0 \\ 7.7 & 18.0\end{array}$

$\begin{array}{rrr}39 & -- & 10 \\ -- & -- & -- \\ 170 & 0 & 40 \\ 130 & 120 & 33\end{array}$

5.5
3.2
3.2
15
--
25
--
00
77
41
70
69
40
63

$\begin{array}{crccc}1.0 & 290 & 30 & -- & -- \\ -- & -- & -- & 5.4 & 4.0 \\ 0 & 230 & 35 & 3.0 & -- \\ 2 & 220 & 24 & 3.0 & -- \\ 6.5 & 92 & 5.0 & 4.6 & -- \\ -- & -- & -- & -- & -- \\ 0.5 & 500 & 27 & 18 & -- \\ -- & -- & -- & -- & -- \\ 170 & 540 & 7.6 & 11 & -- \\ 100 & 380 & 6.7 & 8.8 & -- \\ 13 & 160 & 5.6 & -- & -- \\ 140 & 230 & 2.2 & -- & -- \\ 28 & 57 & 1.5 & -- & -- \\ 83 & 320 & 5.2 & -- & -- \\ 15 & 27 & 0.8 & -- & --\end{array}$

1 Micromos per centimeter at $25^{\circ}$ Celsius (micromhos).

Degrees Celsius $\left({ }^{\circ} \mathrm{C}\right)$.

3 Picocuries per liter ( $p C i / L)$.

4 Micrograms per liter $(\mu g / L)$.

Analyses by U.S. Geological Survey.

6 Residue on evaporation at $180^{\circ}$ Celsius. 


\begin{tabular}{|c|c|c|c|c|c|c|c|c|c|c|c|c|c|}
\hline $\begin{array}{l}\text { Bicar- } \\
\text { bonate } \\
\left(\mathrm{HCO}_{3}\right)\end{array}$ & $\begin{array}{l}\text { Carbon- } \\
\text { ate } \\
\left(\mathrm{CO}_{3}\right)\end{array}$ & $\begin{array}{l}\text { Alka- } \\
\text { linity } \\
\text { (Total } \\
\text { as } \\
\left(\mathrm{CaCO}_{3}\right)\end{array}$ & $\begin{array}{l}\text { Dis- } \\
\text { solved } \\
\text { sulfate } \\
\left(\mathrm{SO}_{4}\right)\end{array}$ & $\begin{array}{l}\text { Dis- } \\
\text { solved } \\
\text { chloride } \\
\text { (Cl) }\end{array}$ & $\begin{array}{l}\text { Dis- } \\
\text { solved } \\
\text { fluo- } \\
\text { ride } \\
\text { (F) }\end{array}$ & $\begin{array}{c}\text { Bromide } \\
(\mathrm{Br})\end{array}$ & $\begin{array}{l}\text { Iodide } \\
\text { (1) }\end{array}$ & $\begin{array}{l}\text { Dis- } \\
\text { solved } \\
\text { silica } \\
\left(\mathrm{SiO}_{2}\right)\end{array}$ & $\begin{array}{l}\text { Dis- } \\
\text { solved Dis- } \\
\text { solids solved } \\
\text { (sum of nitrate } \\
\text { constit- (as N) } \\
\text { uents) }\end{array}$ & $\begin{array}{l}\text { Dis- } \\
\text { solved } \\
\text { boron } \\
(B) \\
(\mu g / L)^{4}\end{array}$ & $\begin{array}{l}\text { Dis- } \\
\text { solved } \\
\text { cadmium } \\
(\mathrm{Cd}) \\
/(\mu \mathrm{g} / \mathrm{L})^{4}\end{array}$ & $\begin{array}{l}\text { Dis- } \\
\text { solved } \\
\text { lithium } \\
(\mathrm{Li}) \\
(\mu \mathrm{g} / \mathrm{L}) 4 /\end{array}$ & $\begin{array}{c}\text { Total } \\
\text { organic } \\
\text { carbon } \\
\text { (C) }\end{array}$ \\
\hline
\end{tabular}

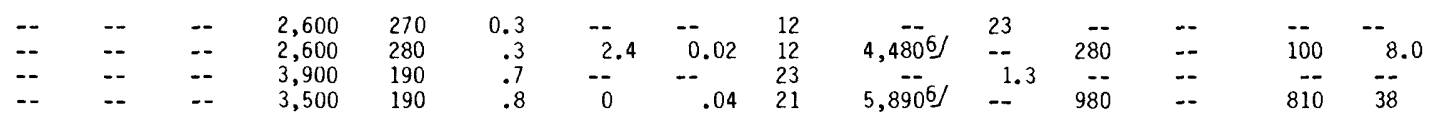

$$
\begin{aligned}
& \begin{array}{rrrrrrrrrrrrrrrrr}
-- & -- & -- & 1,200 & 1,500 & 1.0 & -- & - & & 2.0 & -\overline{0} & 0 & -\overline{0}
\end{array} \\
& \begin{array}{rrrrrrrrrrrrrrrrrrr}
-- & -- & -- & 7,200 & 2,800 & .9 & .5 & .19 & 3.6 & 15,1006 & -- & 1,700 & -- & 1,500 & 18 \\
330 & 0 & 270 & 120 & 14 & 2.3 & -- & -- & 11 & 500 & .4 & -- & -- & -- & -- \\
290 & 0 & 240 & 130 & 21 & 2.2 & -- & -- & 10 & 480 & .4 & -- & -- & -- & -- \\
-- & -- & -- & 2,300 & 360 & 1.9 & .3 & .05 & 12 & 4,4106 & \ldots & 1,400 & -- & 660 & 4.1
\end{array} \\
& \begin{array}{rrrrrrrrrrrrrrrrrrr}
-- & -- & 220 & 110 & 14 & 2.0 & -- & -- & 11 & 460 & -- & 600 & 0 & -- & - \\
-- & -- & -- & -- & -- & -- & .1 & .04 & -- & -- & -- & -- & -- & 60 & 7.1
\end{array}
\end{aligned}
$$

\begin{tabular}{|c|c|c|c|c|c|c|c|c|c|c|c|c|c|c|}
\hline 240 & 0 & 200 & 92 & 18 & 1.5 & -. & -- & 11 & 364 & 0 & -- & 0 & -- & -- \\
\hline 240 & 0 & 200 & 105 & 13 & 1.4 & -- & -- & 11 & 370 & .2 & -- & 0 & -- & -- \\
\hline-- & -- & 190 & 130 & 15 & 1.5 & -- & -- & 10 & -- & -- & 300 & 0 & -- & -- \\
\hline-- & - & 180 & 94 & 9.0 & 1.5 & -- & -- & 10 & -- & -- & 280 & 0 & -- & -- \\
\hline 210 & 0 & 170 & 130 & 15 & -- & - & -- & 11 & 390 & .89 & -- & -- & -- & -- \\
\hline 210 & 0 & 170 & 120 & 14 & - & -- & -- & 12 & 364 & .44 & -- & -- & -- & -- \\
\hline 200 & 0 & 160 & 83 & 11 & 1.3 & -- & -- & 9.0 & 304 & .44 & -- & -- & -- & -- \\
\hline 180 & 0 & 150 & 84 & 10 & 1.2 & -- & -- & 12 & 298 & 1.3 & -- & -- & -- & -- \\
\hline & & & & & & & & & & & & & -- & -- \\
\hline & & & & & & & & & & & & & -- & -- \\
\hline -- & -- & 210 & 49 & 11 & 1.8 & -- & - & 18 & 324 & 3.5 & -- & -- & -- & - \\
\hline 230 & 0 & 190 & 260 & 33 & 1.3 & -- & -- & 19 & 635 & 8.0 & -- & -- & -- & -- \\
\hline-- & -- & 150 & 24 & 16 & .5 & - & -- & 31 & 273 & 12 & -- & -- & -- & -- \\
\hline-- & -- & -- & 150 & 57 & 2.6 & -- & -- & 7.0 & 788 & .5 & - & - & -- & - \\
\hline-- & $-\cdot$ & -- & -- & $=$ & -- & .1 & .02 & -- & -- & -- & 470 & 1.0 & 110 & 6.6 \\
\hline 380 & 10 & 330 & 110 & 35 & 2.8 & - & -- & 8.0 & 586 & 1.3 & -- & -- & -- & -- \\
\hline 390 & 0 & 320 & 100 & 49 & -- & -- & -- & -- & -- & $\cdots$ & -- & -- & -- & -- \\
\hline-- & -- & 170 & 88 & 6.0 & 1.5 & -- & -- & 10 & 324 & -- & 400 & 0 & -- & -- \\
\hline -. & -- & -- & -- & -- & -. & .1 & .03 & -- & -- & -- & -- & -- & 70 & 0.3 \\
\hline-- & -- & -- & 350 & 530 & 3.3 & -- & -- & 19 & 1,500 & - & -- & 0 & -- & -- \\
\hline-- & -- & $\cdots$ & -- & -- & -- & .1 & .03 & - & -- & -- & -- & -- & 240 & 2.9 \\
\hline-- & -- & 320 & 1,300 & 370 & 1.6 & 0 & .44 & 9.6 & 2,8506 & -- & 490 & -- & 310 & 5.5 \\
\hline-- & - & 310 & 780 & 210 & 1.6 & -- & -- & 9.0 & -- & -- & 42 & 0 & -- & -- \\
\hline -- & -- & 180 & 150 & 140 & 2.0 & .1 & .02 & 8.7 & $6276 /$ & $=$ & 240 & -- & 60 & 0.3 \\
\hline -- & -- & 380 & 2,000 & -- & .6 & -- & -- & 14 & 3,280 & 0 & -- & -- & -- & -- \\
\hline-- & -- & 170 & 220 & 14 & .9 & -- & -- & 9.0 & 498 & 0 & -- & -- & -- & -- \\
\hline-- & -- & 320 & 800 & 97 & 2.1 & -- & -- & 9.0 & -- & -- & 71 & 0 & -- & - \\
\hline-- & -- & 140 & 120 & 7.9 & .7 & -- & -- & 15 & 333 & 10.6 & -- & -- & -- & -- \\
\hline-- & -- & -- & 75 & 13 & 2.0 & -- & -- & 15 & 390 & -- & 610 & 0 & -- & $=$ \\
\hline- & -- & $=$ & -- & -- & -- & .1 & .04 & $=-$ & $\overline{-}$ & -- & -- & -- & 60 & 2.1 \\
\hline-- & -- & 170 & 100 & 7.4 & 1.3 & -- & -- & 10 & 331 & 0 & -- & -- & -- & -- \\
\hline-- & -- & 200 & 150 & 8.0 & 1.8 & - & -- & 10 & 450 & .4 & -- & - & -- & -- \\
\hline
\end{tabular}


Most likely, the main source of the contamination came from the cement grout along the outside of the casing. The sampled water probably was in contact with this grout for an extended period of time. Because of these questionable values of $\mathrm{pH}$, the values of alkalinity, bicarbonate, carbonate, and noncarbonate hardness also were considered questionable and were not listed in table 4.

Large values of $\mathrm{pH}$ also occurred in the samples collected from two test holes completed in the Cheyenne aquifer and from all three test holes completed in the Dakota aquifer. The questionable values of $\mathrm{pH}$ ranged from 9.1 to 10.3 and appeared to be much too large. These questionable pH values plus alkalinity, bicarbonate, carbonate, and noncarbonate hardness values, which also were considered questionable, were not listed in table 4.

A summary of chemical analyses of water from Jurassic, Cheyenne, and Dakota aquifers is presented in table 5. This suminary is based on the chemical analyses listed in table 4 and can be used to compare the quality of water in the three aquifers examined during this study. The minimum, maximum, mean, and median values for each chemical constituent or property of water by aquifer is included in table 5. Also given are the number of analyses that are the basis for these values. Recommended maximum concentrations for public supply are given for some constituents (U.S. EnvironInental Protection Agency, 1976; 1979). Ratios by weight were calculated and listed for potassium to sodium, lithium to sodium, sulfate to chloride, fluoride to chloride, bromide to chloride, iodide to chloride, boron to chloride, and sodium to chloride. The minimum, maximum, mean, and median values of these ratios are listed in table 5 by aquifer.

The classification of the salinity of water that was used in this report is based on the concentration of dissolved solids (Hem, 1970, p. 219). The terms used to describe the water include fresh, slightly sal ine, moderately saline, very saline, and brine. Another classification of water quality is that of the Kansas statutory definition of usable water in oilfield pollution-control statutes enforced by the Kansas Department of Health and Environment and the Kansas State Corporation Commission (1979, p. 17) and is based on the concentration of chloride. They use the terms freshwater and usable water in the protection of water from oilfield pollution.

\section{Jurassic Aquifer}

The description of the chemical composition of water in the Jurassic aquifer in Hamilton and Kearny Counties is based on six chemical analyses of water (table 4). In water from the Jurassic aquifer, sodium is the predominant cation and sulfate and chloride as the predominant anions, which indicate sodium sulfate and sodium chloride types of water. The water is moderately saline and very hard (see "Definition of Terms" for an explanation of the classification of salinity of water based on dissolved solids and an explanation of the hardness classification). The chemical composition of Jurassic water is illustrated in figure 15 by the ion-concentration graphs of water from selected wells in the Jurassic aquifer. 


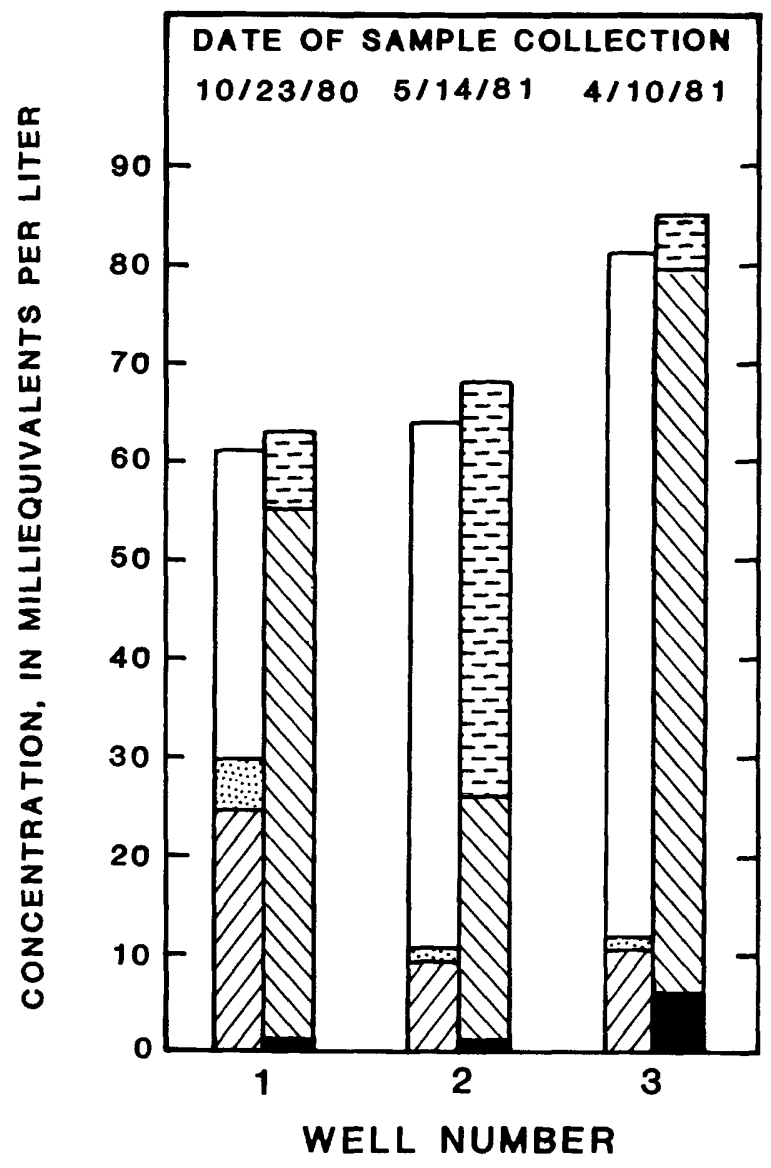

21-40W-17CAD

$\odot$

1

\section{EXPLANATION}

CATIONS

Sodium and potassium

Magnesium

Calcium

\section{ANIONS}

Chloride and fluoride

Sulfate

Bicarbonate

WELL USED FOR THE COLLECTION OF WATER FOR CHEMICAL ANALYSIS --Numbers refer to well location and number

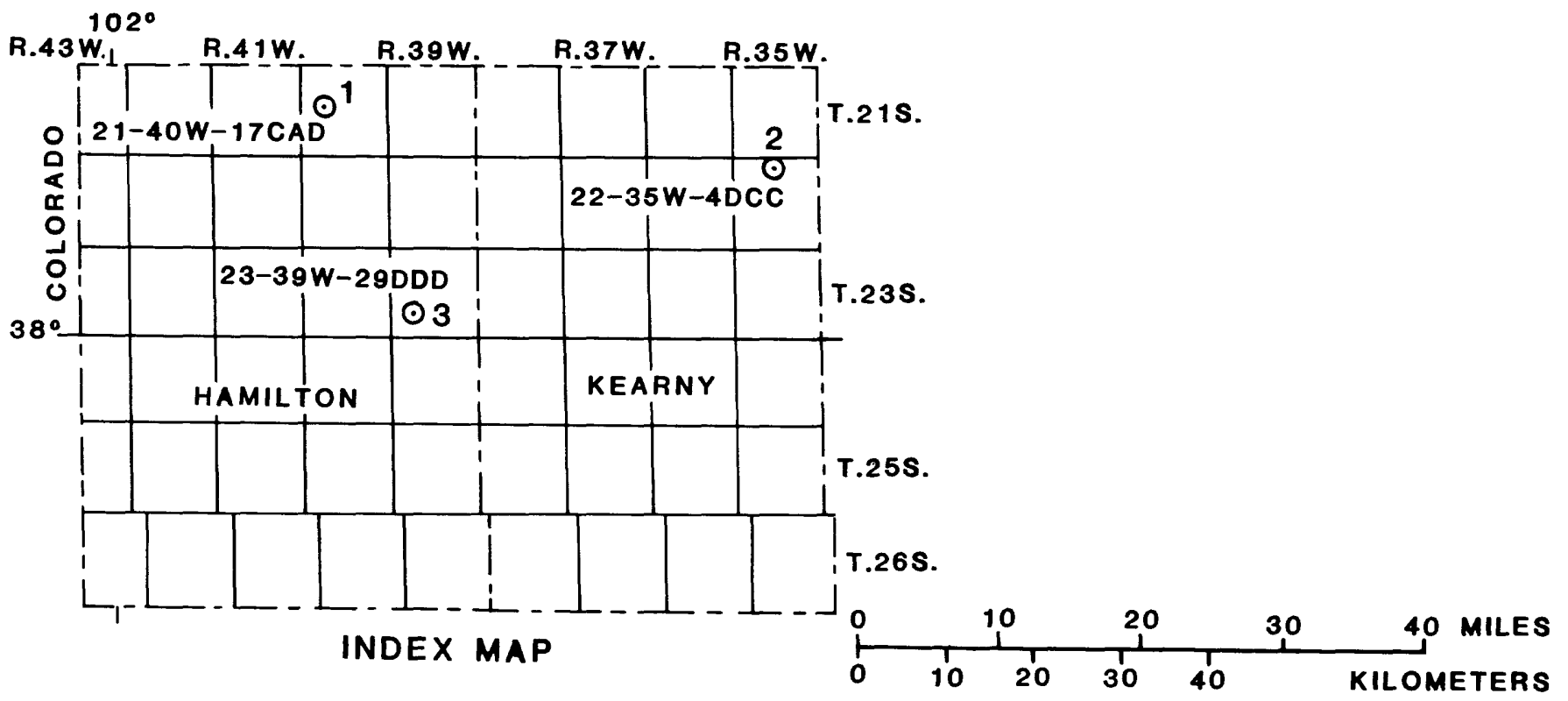

Figure 15.--Chemical composition of water from selected wells completed in Jurassic aquifer. 


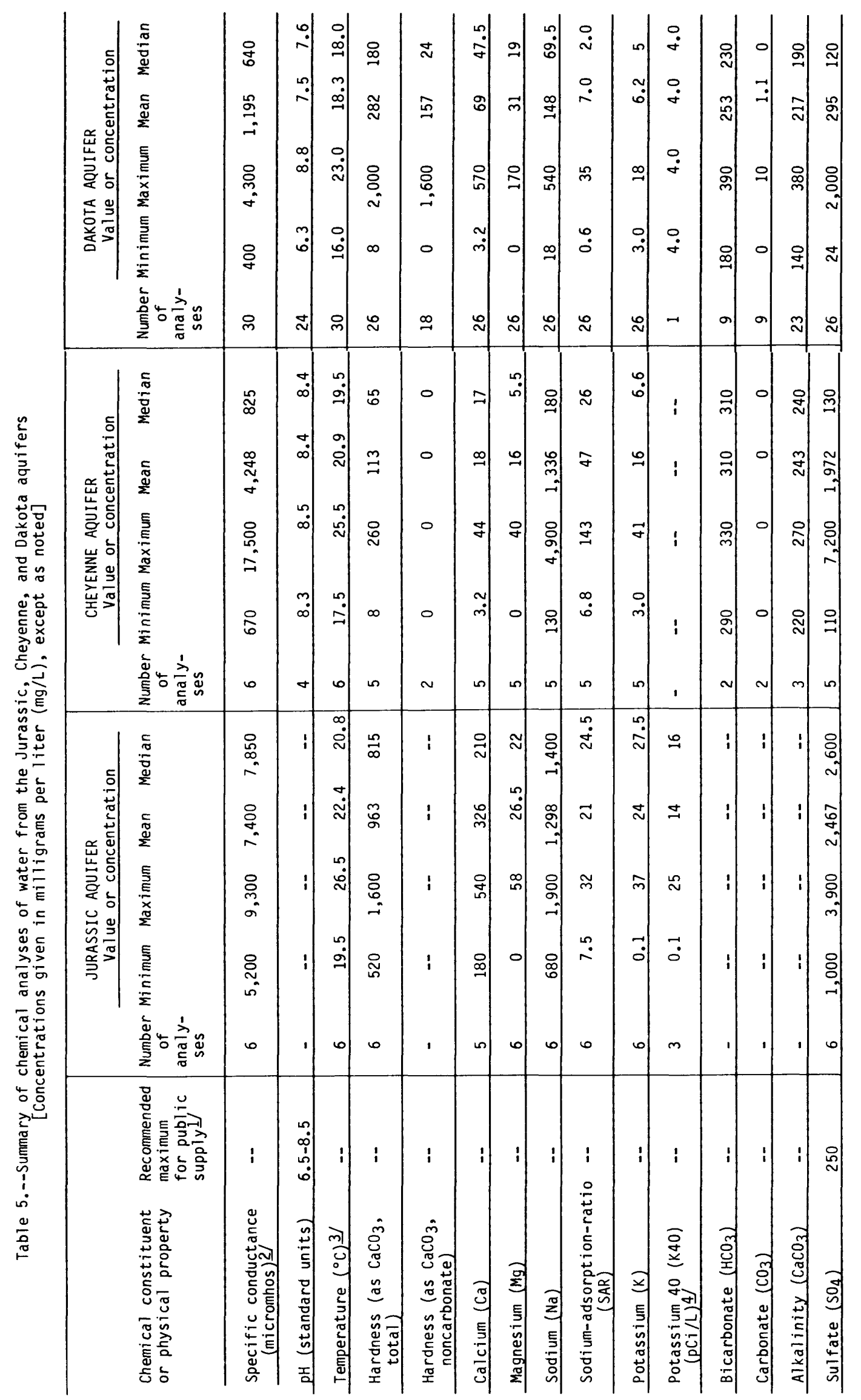




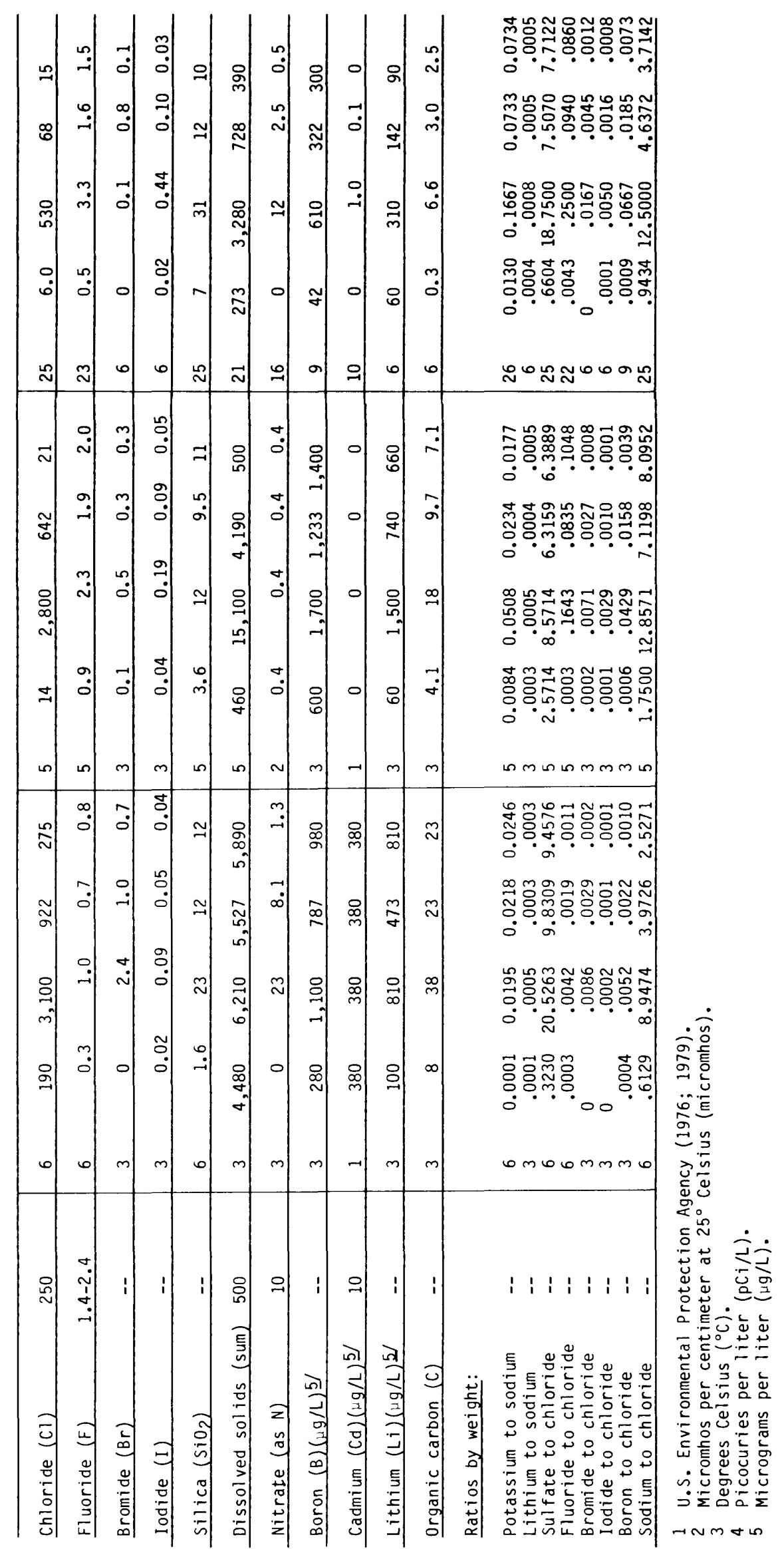


Water from the Jurassic aquifer generally is the most mineralized and the least suitable for any use of the three aquifers examined for this study. This conclusion is based on the fact that the water is characterized by the largest values for most of the chemical constituents or properties listed in table 5. For example, water from the Jurassic aquifer contains the largest median values or concentrations for specific conductance, temperature, hardness, calcium, sodium, potassium, potassium-40, sulfate, chloride, bromide, dissolved solids, nitrate, cadmium, and organic carbon. The water also has the largest maximum values or concentrations for temperature, potassium-40, chloride, bromide, nitrate, cadmium, and organic carbon.

In an attempt to identify the presence and source of saline water either from the disposal of oilfield brine or from natural geologic processes in the water samples collected from the Jurassic aquifer, various ratios by weight were calculated for selected chemical constituents and were listed in table 5.

Based on the sodium to chlorine ratios in water collected from the Jurassic aquifer, oilfield brine probably is not the source of the saline water. Leonard (1964) reported that in south-central Kansas the ratio of sodium to chloride in waters containing oilfield brine normally is less than 0.60 . None of the sodium to chloride ratios of water sampled from the Jurassic during this study were less than 0.60 . The ratios ranged from 0.61 to 8.95 and had a median value of 2.5271. The smallest ratio, 0.61 , was for a water sample from well 22-35W-40CC in Kearny County.

White and others (1963) reported that oilfield brines, in which sodium and chloride predominate, commonly are characterized by a relatively large ratio of iodide to chloride and relatively small ratios of potassium to sodium, lithium to sodium, and sulfate to chloride. They also stated that chloride brines, in which calcium predominates, generally have a relatively large ratio of bromide to chloride and relatively small ratios of potassium to sodium, lithium to chloride, sulfate to chloride, fluoride to chloride, iodide to chloride, and boron to chloride.

The calculated ratios do not indicate that oilfield brines were the probable source of the saline water. The most likely sources for much of the saline water are from the natural dissolution of minerals in the confining beds, from leakage of saline water from underlying Permian formations, and from interstitial saline water. Water from the Jurassic aquifer has relatively small ratios of potassium to sodium, lithium to sodium, fluoride to chloride, bromide to chloride, iodide to chloride, and boron to chloride. The water has relatively large ratios of sulfate to chloride and sodium to chloride.

The relatively large sodium and chloride concentrations probably were derived from the dissolution of bedded marine evaporites (halite) of Permian age that have migrated through a hydraulic connection into Jurassic rocks. Sodium also may be due, in part, to ion exchange of calcium with sodium from clay material. Calcium and sulfate generally are derived from the dissolution of gypsum and gypsiferous shale of Permian and Jurassic age. Silica can be derived from the quartz and chalcedony sandstone. 


\section{Cheyenne Aquifer}

The chemical quality of water from the Cheyenne aquifer generally ranges from fresh to moderately saline and from soft to very hard in Hamilton and Kearny Counties. Six chemical analyses of water from the Cheyenne are given in table 4. The chemical composition of Cheyenne water is illustrated by five ion-concentration graphs in figure 16. Sodium is the predominant cation, and sulfate and bicarbonate are the predominant anions. The predominant ions indicate sodium sulfate and sodium bicarbonate chemical types of water.

The chemical quality of water in the Cheyenne aquifer varies considerably from one locality to another. Therefore, water from the Cheyenne aquifer ranges from being less mineralized to much more mineralized than the water in the Jurassic aquifer. The best example to illustrate this considerable variation is the concentration of dissolved solids in the Cheyenne aquifer, which ranged from 460 to $15,100 \mathrm{mg} / \mathrm{L}$ (tables 4 and 5).

The chemical quality of water in the Cheyenne aquifer is characterized by the range, mean, and median values given in table 5 . Of the three aquifers examined in this study, water from the Cheyenne aquifer has the smallest median concentrations of hardness, calcium, magnesium, carbonate, nitrate, and cadmi um. However, the water has the largest median values or concentrations for $\mathrm{pH}$, sodium, SAR, bicarbonate, fluoride, boron, and lithium. The water also has the largest maximum values or concentrations for specific conductance, sodium, SAR, potassium, sulfate, dissolved solids, boron, and lithium.

Water from the Cheyenne aquifer has relatively large ratios of sulfate to chloride, fluoride to chloride, iodide to chloride, boron to chloride, and sodium to chloride. The relatively large ratios of sodium to chloride had a mean value of 7.12 , which is too large to indicate the presence of oilfield brine. The water has relatively small ratios of potassium to sodium, lithium to sodium, and bromide to chloride. Most of the saline water in the Cheyenne aquifer probably leaked upward from the underlying Jurassic and Permian formations.

The relatively large sodium concentration in water from the Cheyenne aquifer probably is due, in part, to ion exchange of calcium with sodium from clay material and, in part, from the dissolution of halite and alkali feldspar in underlying formations. Also, some of the sodium ions may have migrated into the sandstone from other rock formations associated with the sandstone. Calcium and sulfate generally are derived from the dissolution of gypsum and gyupsiferous shale. Fluoride can be derived from the dissolution of calcium fluoride, apatite, hornblende, and micas in shale and sandstone. Relatively large concentrations of boron may be derived from granitic and pegmatitic rocks in clastic sandstone and from marine shale. The relatively large bicarbonate concentration can be derived from the dissolution of calcite in shale and from atmospheric carbon dioxide and carbonaceous material, which is also a source for carbon dioxide in the Cheyenne. Relatively large lithium concentrations may have been derived from the weathering of pegmatites in clastic sandstone. 


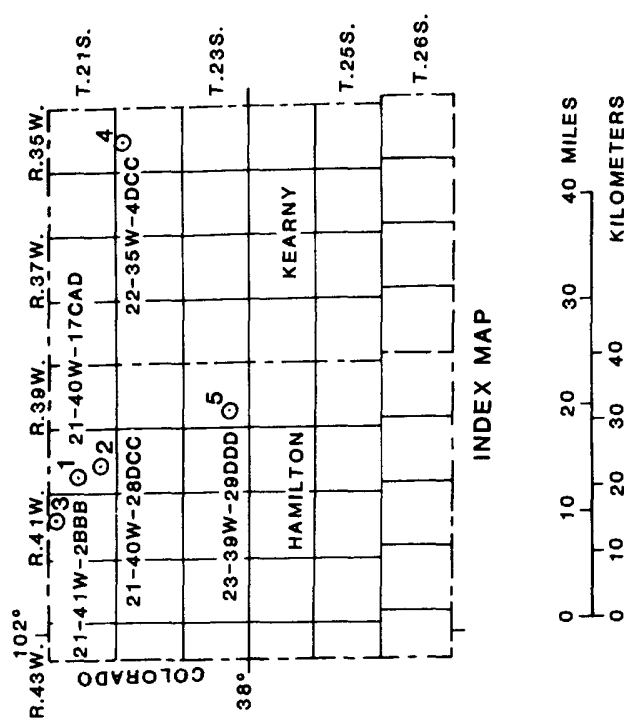

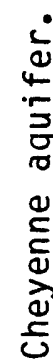
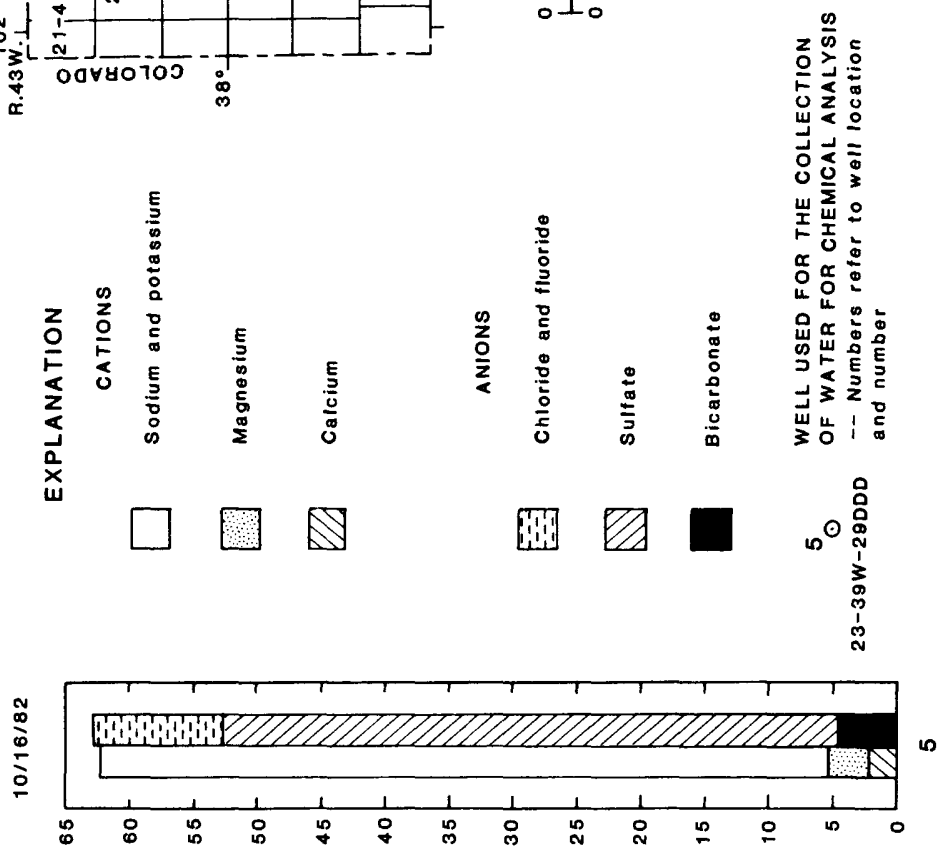

다

멍

흠

$\frac{n}{5}$

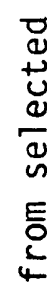

文

4

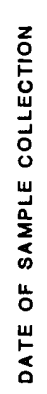

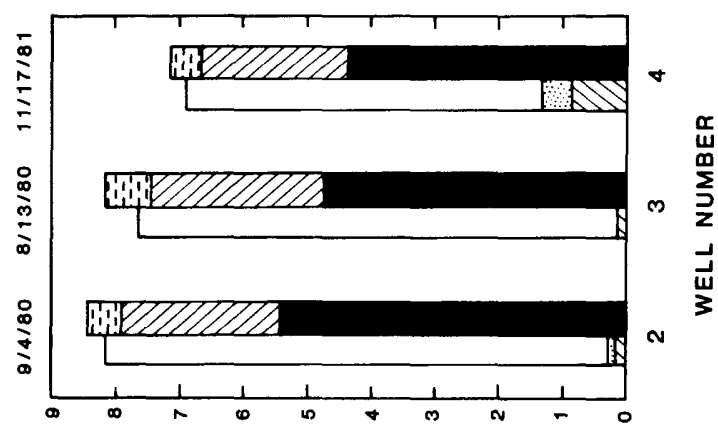

동

\begin{tabular}{l}
$\overline{0}$ \\
$\frac{0}{0}$ \\
\hline \\
\hline \\
\hline \\
\hline
\end{tabular}

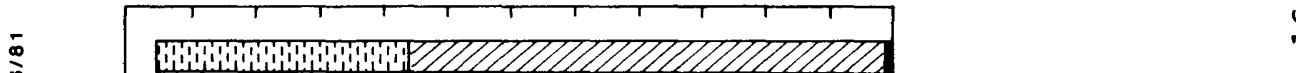

ปั 


\section{Dakota Aquifer}

The discussion of the quality of water in the Dakota aquifer in Finney, Ford, Gray, Hamilton, and Kearny Counties is based mainly on 30 chemical analyses of water (table 4). The chemical composition of water in the Dakota is illustrated in figure 17 by the ion-concentration graphs of water from nine selected wells. Generally, sodium and calcium are the predominant cations, and bicarbonate, sulfate, and chloride are the predominant anions. The water ranges from fresh to moderately saline and from soft to very hard. The water was fresh except for three samples. Two samples are slightly saline waters and are sodium sulfate and sodium chloride types, and one sample is moderately saline water and is a calcium sulfate type.

The water from the Dakota aquifer generally is the least mineralized of the ground water examined during this study; however, the chemical quality is quite variable. The water is characterized by the smallest median values or concentrations of specific conductance, $\mathrm{pH}$, temperature, sodium, SAR, potassium, bicarbonate, carbonate, alkalinity, sulfate, chloride, bromide, silica, dissolved solids, boron, cadmium, lithium, and organic carbon of the three aquifers examined. However, the water has the largest maximum values or concentrations for $\mathrm{pH}$, hardness, calcium, magnesium, bicarbonate, carbonate, alkalinity, fluoride, iodide, and silica.

Water from the Dakota aquifer has relatively large ratios of sulfate to chloride, fluoride to chloride, bromide to chloride, iodide to chloride, boron to chloride, and sodium to chloride. The water has relatively small ratios of potassium to sodium and lithium to sodium. The relatively large ratios of sodium to chloride had a mean value of 4.64 (table 5), which generally is too large to indicate the presence of oilfield brine. Thus, the relatively large sodium to chloride ratios did not suggest any contamination from oilfield activities.

A generalized distribution of dissolved-solids concentrations in water in the Dakota aquifer is shown in figure 18, is based on available chemical-quality data, and is modified from Kume and Spinazola (1983). The crosshatched area shows where the concentrations of dissolved solids were less than $500 \mathrm{mg} / \mathrm{L}$ in the southern one-half of the study area and where the aquifer is unconfined by shales or confined by shales but within about 15 to $30 \mathrm{mi}$ of the southern limit of these confining shales. The concentrations are smallest here because of freshwater recharge from the overlying High Plains aquifer.

Concentrations greater than $500 \mathrm{mg} / \mathrm{L}$ occur in the northern one-half of the area where the Dakota aquifer is confined by shales and lies at greater depths below the land surface. In general, the dissolved-solids concentrations tend to increase northward with increasing depth of the aquifer. Four isolated places have concentrations greater than 1,000 $\mathrm{mg} / \mathrm{L}$, and perhaps, some places reflect saline-water intrusion by natural geologic processes from the underlying Permian rocks. In the northeastern part of the area, saline water occurs at shallow depths because of salinewater intrusion from the underlying Permian rocks. 

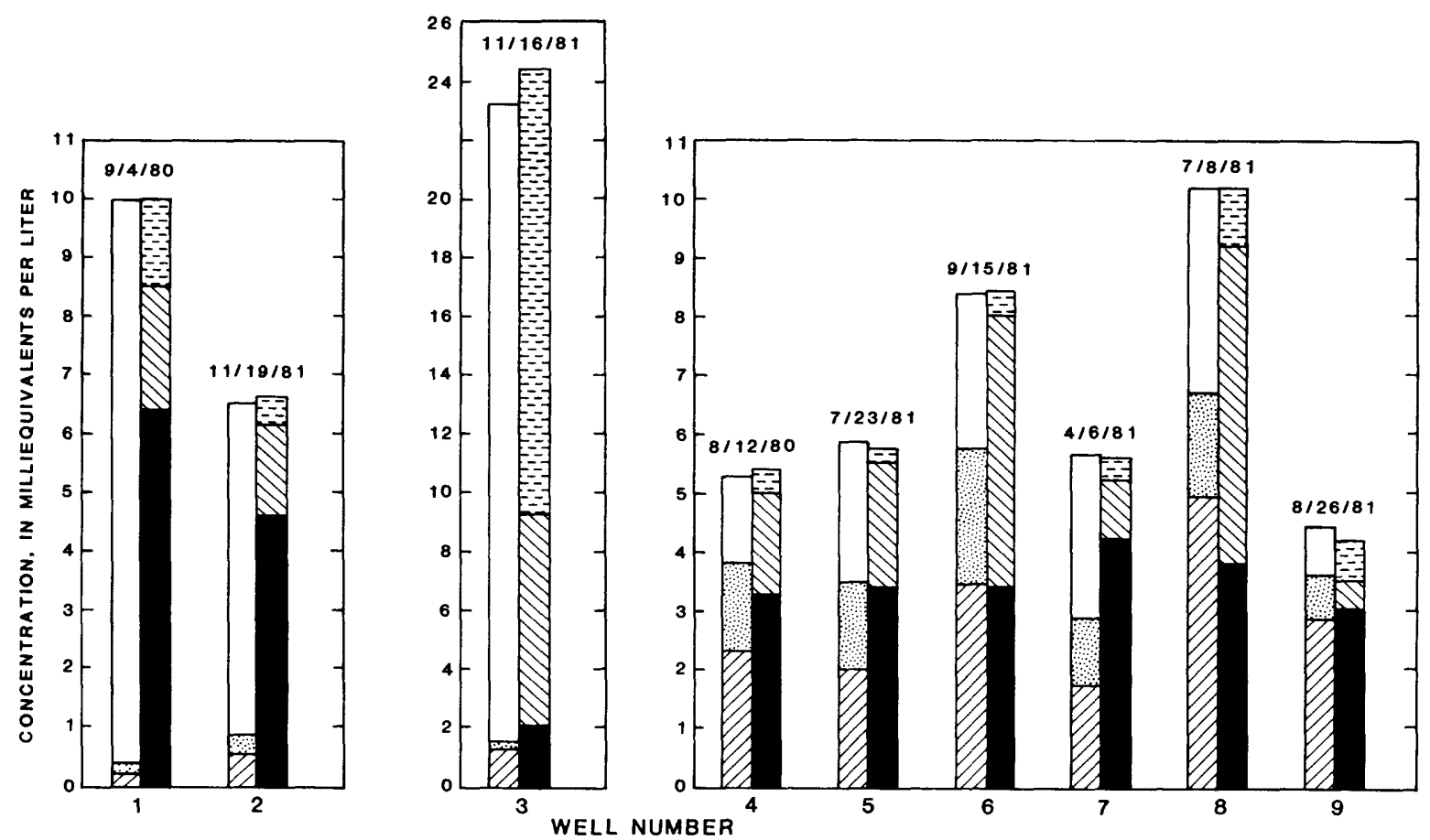

\section{EXPLANATION}

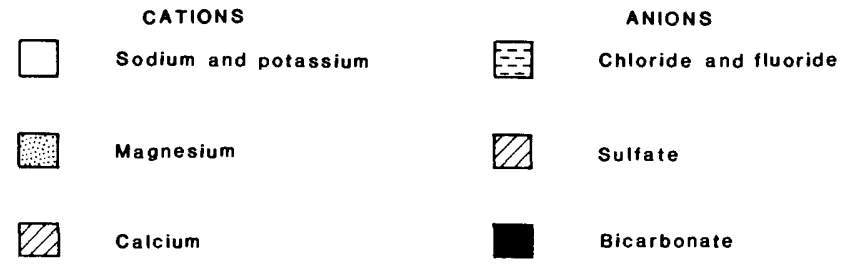

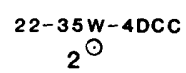

WELL USED FOR THE COLLECTION OF WATER FOR CHEMICAL ANALYSIS - Numbers refer to well location and number
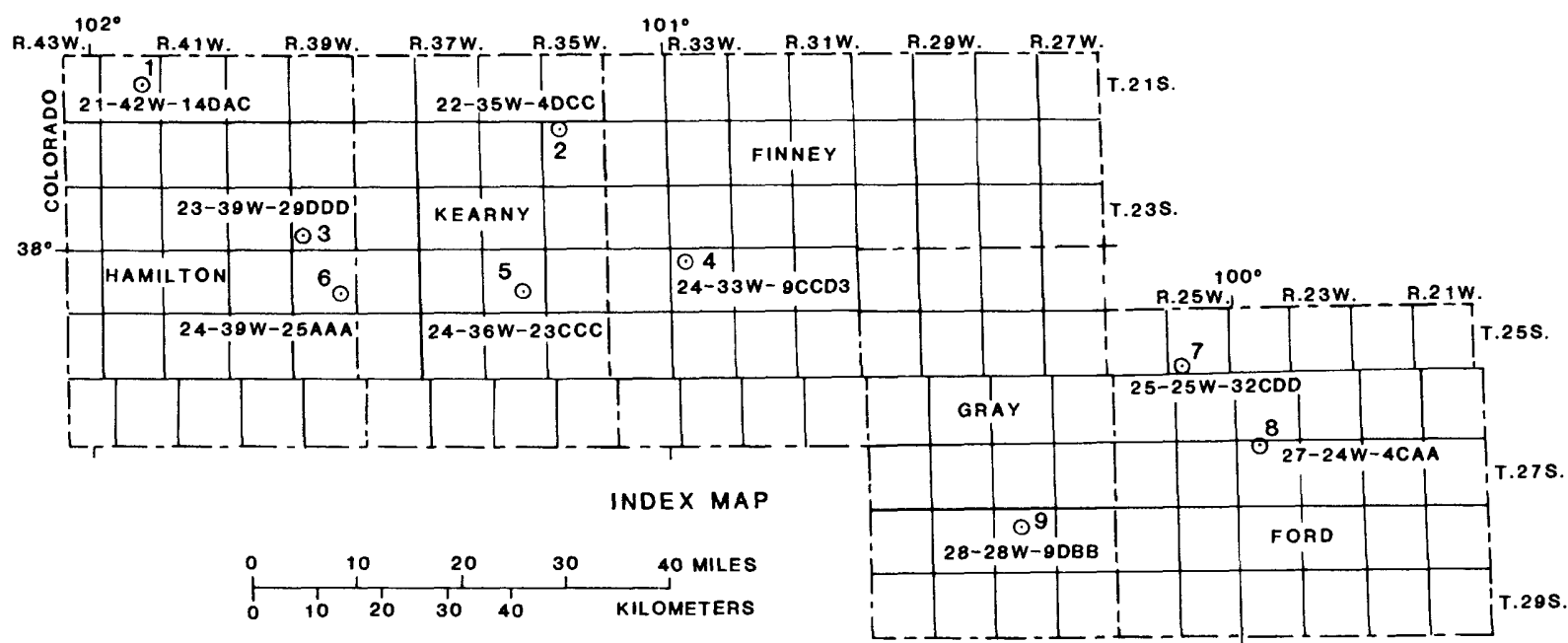

Figure 17.--Chemical composition of water from selected wells completed in Dakota aquifer. 


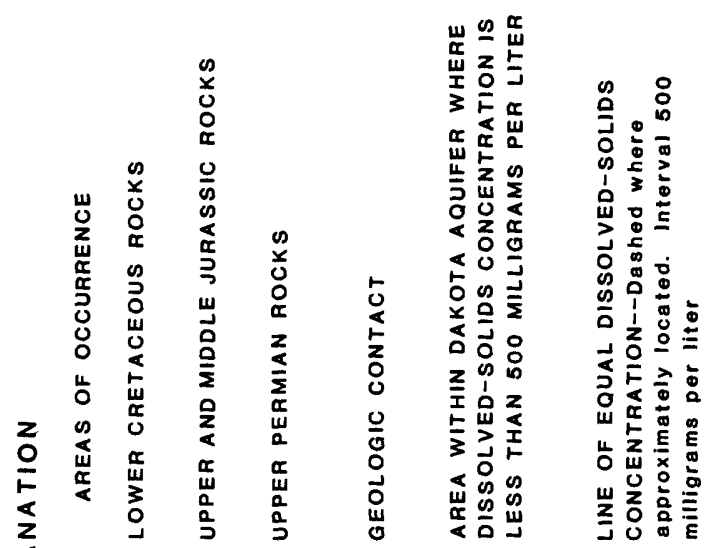

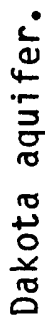

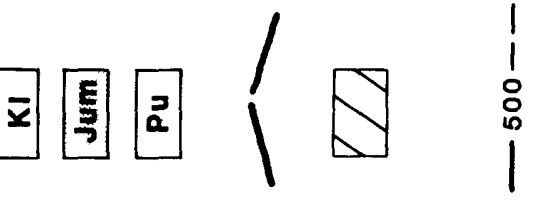

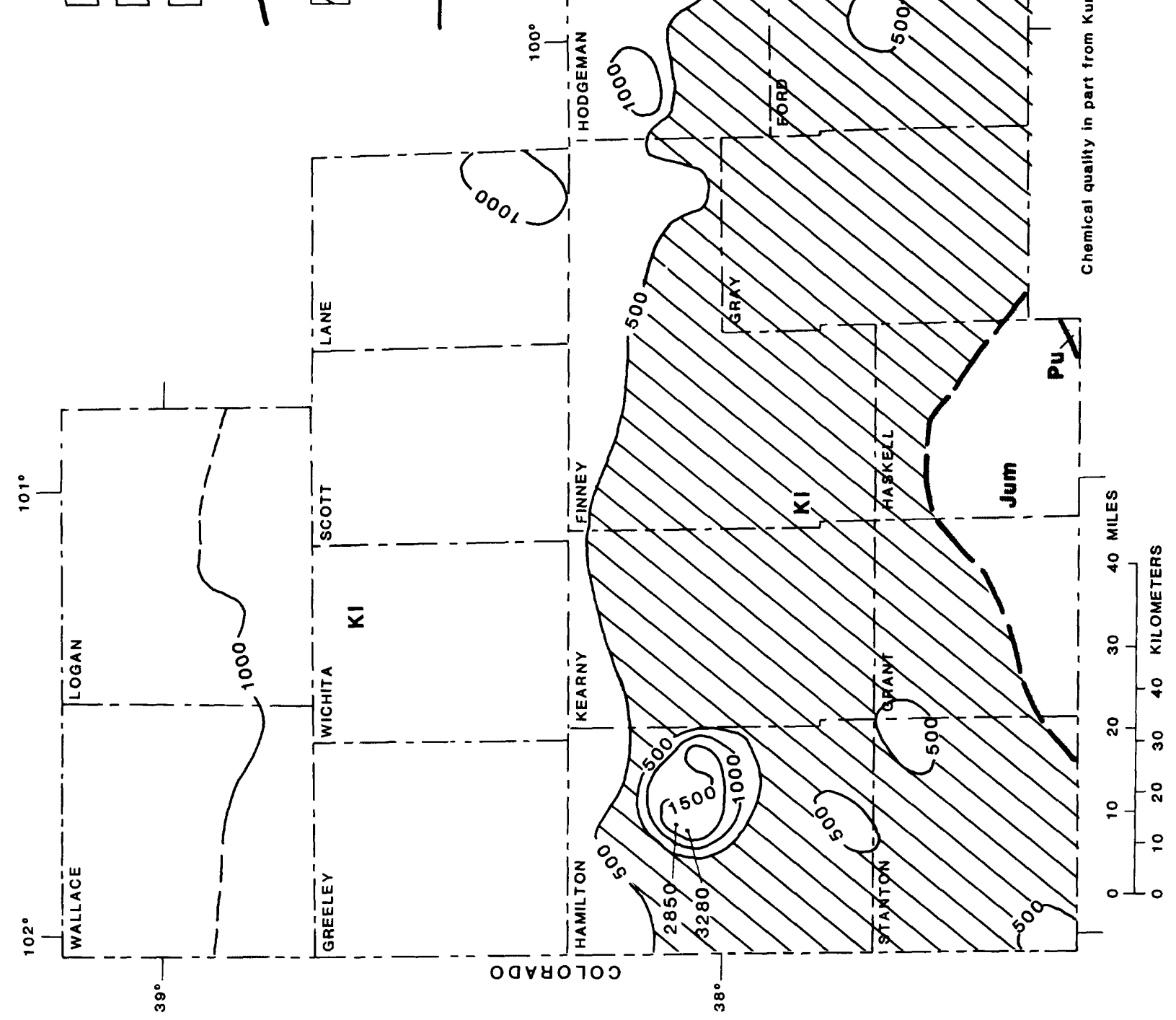

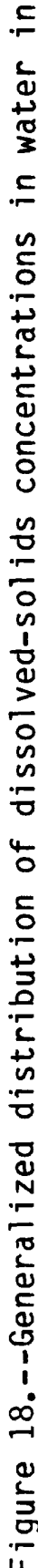


The areal occurrence of chemical types of water in the Dakota aquifer is shown in figure 19, is based on available chemical data, and is modified from Kume and Spinazola (1983). Sodium bicarbonate type water predominates throughout the northern two-thirds of the study area, but calcium bicarbonate type water predominates in much of the southern one-third. Locally, other chemical types of water include calcium sulfate, sodium chloride, and sodium sulfate. The sodium bicarbonate water probably represents unmixed aquifer water. The calcium bicarbonate water probably represents a mixed water that includes freshwater recharge from the overlying High Plains aquifer. The other minor chemical types that are present probably are mixed waters from the leakage of saline water from the underlying shales, red beds, and evaporite beds.

The relatively large concentrations of calcium and sulfate in water in the Dakota probably were derived from the dissolution of gypsum and gypsiferous shale. Calcium and bicarbonate probably were derived from the dissolution of freshwater limestone and caliche and the atmospheric carbon dioxide available from the overlying and unconfined High Plains aquifer. The relatively large sodium concentrations may be due, in part, to ion exchange of calcium with sodium from shale and clay material and, in part, from the dissolution of halite and alkali feldspar in underlying formations. Silica can be derived from the quartz and chalcedony sandstone.

\section{Suitability of Water for Various Uses}

The following discussion will be concerned about whether the water from the Jurassic, Cheyenne, and Dakota aquifers is satisfactory for various uses. Water-use determination is based upon certain standards or tolerances that have been established for the intended uses. For irrigation supplies, a diagram widely used to evaluate waters has been published by the U.S. Salinity Laboratory Staff (1954). For stock supplies, the standards are similar to those for drinking water except that livestock may be able to tolerate considerably larger concentrations of dissolved solids. For domestic drinking water and public-water supply, the U.S. Environmental Protection Agency $(1976$; 1979) has established mandatory and recommended criteria for quality of water. For industrial supplies, the standards vary widely and are based on the industrial application.

\section{Irrigation}

The chemical characteristics of water that are most important in determining its suitability for irrgation are: (1) The total concentration of soluble salts (salinity); (2) the relative proportion of the concentration of sodium (alkali) to the concentration of calcium plus magnesium (U.S. Salinity Laboratory Staff, 1954); (3) the concentration of boron or other elements that may be toxic if present in concentrations greater than the tolerances for selected crops; and, under some conditions, (4) the bicarbonate concentrations when there also is large sodium concentrations in the water because of the possibility of residual sodium bicarbonate alkalinity, which could increase in the soils. The effects of this last chemical characteristic would be similar to that of alkali soils. 

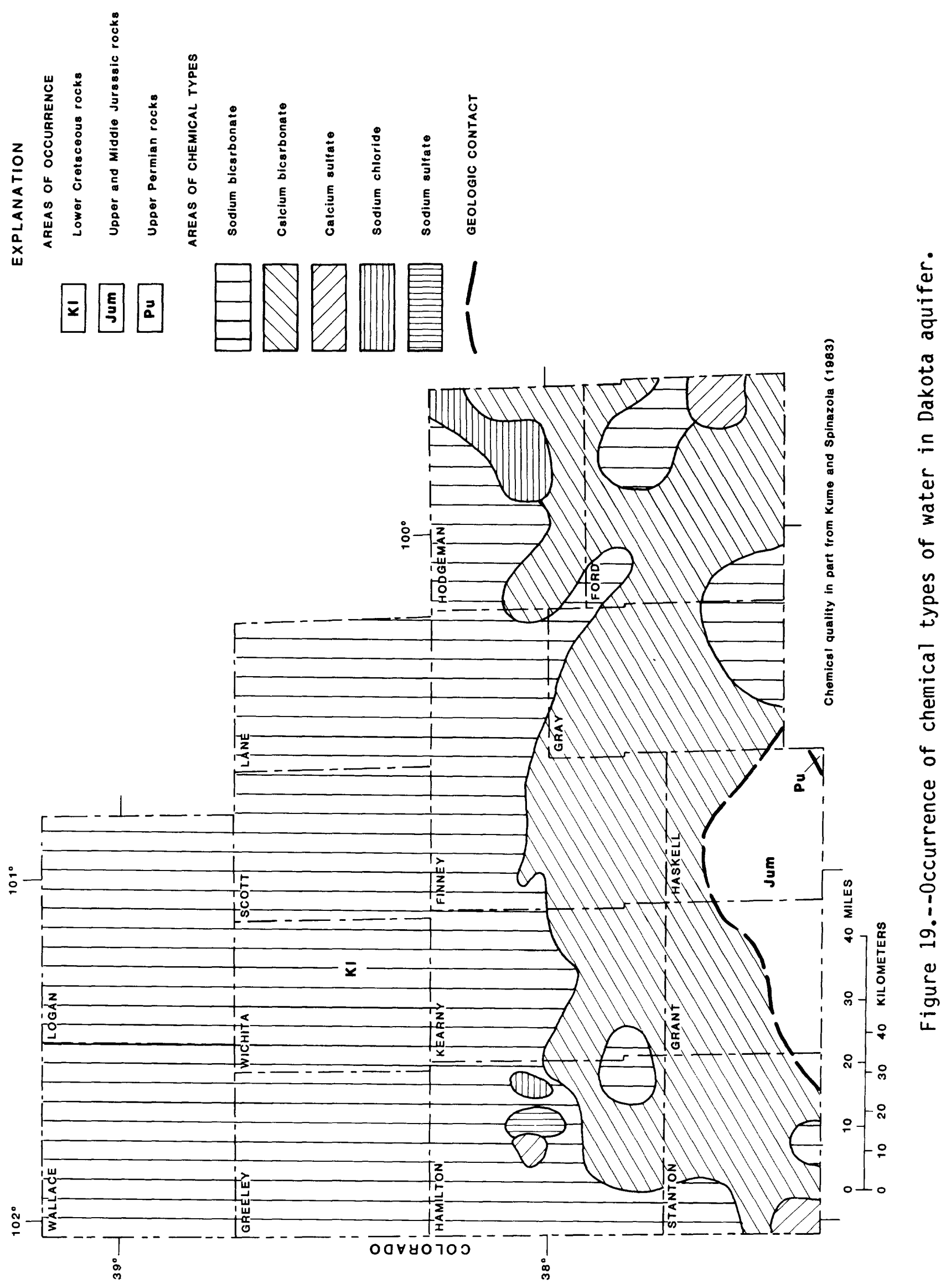
The potential for water that contains a large concentration of dissolved solids (large specific-conductance value) to cause the soil salinity to increase is called the "salinity hazard" of the water. To estimate a dissolved-solids value, multiply a specific-conductance value by a number between 0.55 and 0.75 ; the larger values generally are associated with water containing a large sulfate concentration (Hem, 1970, p. 99). Soil types, drainage, the quantity of water used, and other factors determine whether use of a given water for irrigation will cause an increase in soil salinity. An increase in soil salinity can have an undesirable effect when irrigating crops with a high-salinity-hazard water.

A large concentration of sodium in irrigation water can have undesirable effects on the soil through the process of ion exchange between sodium in the water and calcium and magnesium in the soil. The ion exchange produces an "alkali soil" in which the soil particles have deflocculated and have impaired the soil texture. The soil becomes difficult to till and to drain. The potential for water to deflocculate the soil particles is called the "sodium hazard" of the water. The potential for irrigation water to produce undesirable conditions depends not only on the sodium concentration but also on the sodium concentration in relation to the calcium and magnesium concentrations. The potential is expressed as a sodium-adsorption-ratio (SAR). Small SAR values are desirable for irrigation water.

The summary of chemical analyses of water from the Jurassic aquifer (table 5) indicates that the water in Hamilton and Kearny Counties is unsuitable for irrigation. The sodium hazard ranges from high to very high, and the salinity hazard is very high. The median value of the specific conductance is $7,850 \mu \mathrm{mhos} / \mathrm{cm}$ at $25^{\circ} \mathrm{C}$, and the SAR has a median value of 24.5 .

The results of chemical analyses of water from the Cheyenne aquifer, summarized in table 5, show that the water in Hamilton County is-unsuitable for irrigation, but in Kearny County, it is suitable for irrigation. In Hamilton County, the sodium and salinity hazards are very high. In Kearny County, the sodium and salinity hazards are medium.

The results of chemical analyses of water from the Dakota aquifer, summarized in table 5, indicate that most of the water is suitable for irrigation, but some water is not. A classification diagram (fig. 20) illustrates the suitability for irrigation of 24 water samples (table 4 ) from selected wells completed in the Dakota aquifer. The diagram shows that the sodium hazard is low for 16 water samples, but for 8 samples the sodium hazard ranges from medium to very high. The salinity hazard is medium for 14 water samples, but for 10 samples the salinity ranges from high to very high. The values of SAR and specific conductance and the salinity and sodium hazards of water from selected wells used in the diagram (fig. 20) are listed in table 6 . SAR ranges from 0.6 to 35 , and specific conductance ranges from 400 to $4,300 \mu \mathrm{mhos} / \mathrm{cm}$ at $25^{\circ} \mathrm{C}$. These ranges are quite wide, and they point out the variability of the chemical quality of water from the Dakota aquifer. 


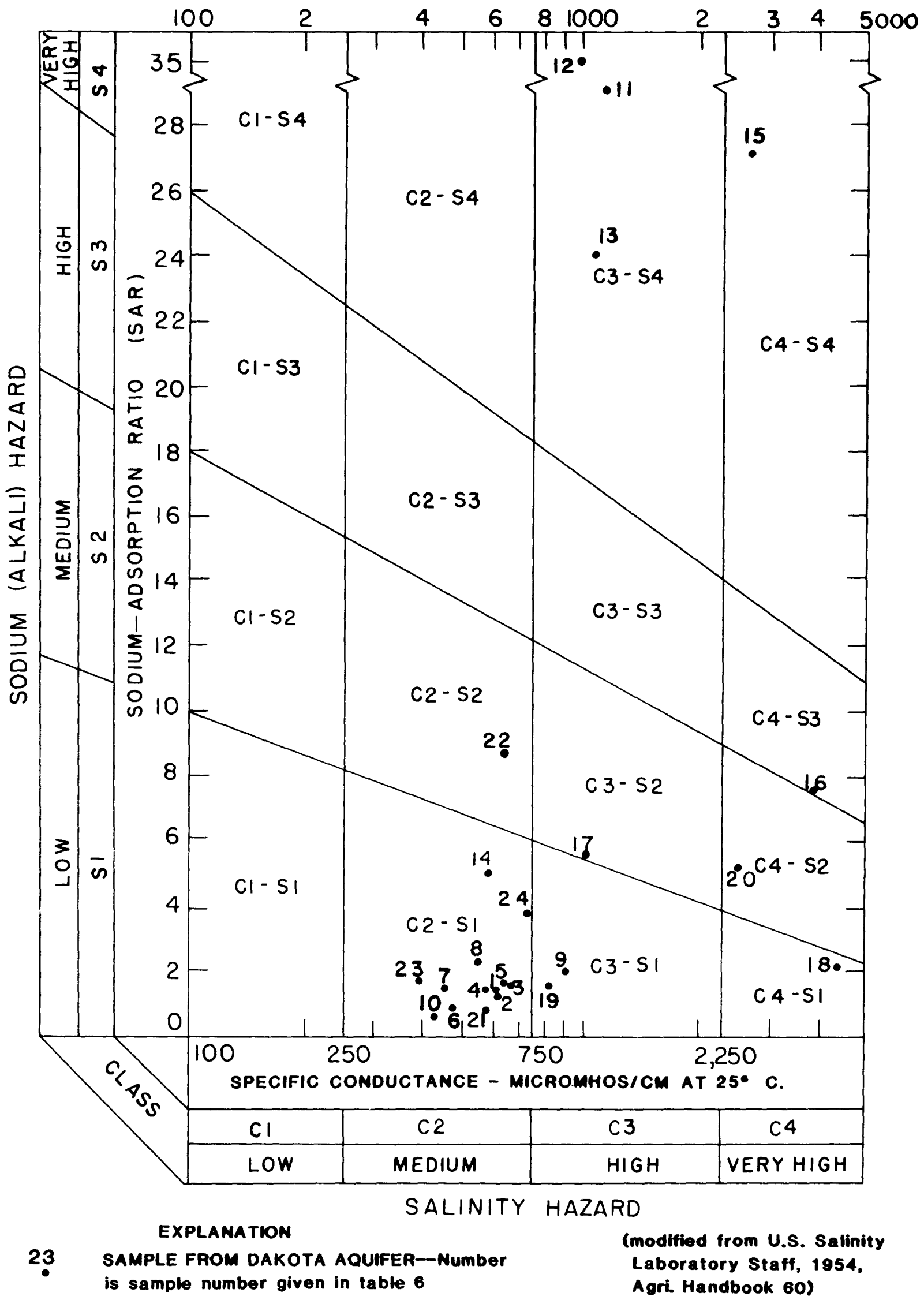

Figure 20.--Classification of selected water samples in Dakota aquifer describing suitability for irrigation. 
Table 6.--Sodium-adsorption-ratio, specific conductance, salinity hazard, and sodium hazard of water from selected wells completed in the Dakota aquifer

\begin{tabular}{|c|c|c|c|c|c|c|}
\hline $\begin{array}{l}\text { Sample } \\
\text { nuinber } \\
\text { (shown } \\
\text { in fig- } \\
\text { ure 20) }\end{array}$ & $\begin{array}{l}\text { County } \\
\text { name }\end{array}$ & Well number & $\begin{array}{l}\text { Sodium- } \\
\text { adsorption- } \\
\text { ratio } \\
\text { (SAR) }\end{array}$ & $\begin{array}{l}\text { Specific } \\
\text { conductance } \\
\text { (micromhos per } \\
\text { centimeter at } \\
25{ }^{\circ} \mathrm{C} \text { ) }\end{array}$ & $\begin{array}{l}\text { Salinity } \\
\text { hazard }\end{array}$ & $\begin{array}{l}\text { Sodium } \\
\text { hazard }\end{array}$ \\
\hline $\begin{array}{l}1 \\
2 \\
3 \\
4 \\
5\end{array}$ & $\begin{array}{c}\text { Finney } \\
\text { Do. } \\
\text { Do. } \\
\text { Do. } \\
\text { Do. }\end{array}$ & $\begin{array}{l}23-34 W-13 D B B \\
23-34 W-14 C C C \\
23-34 W-15 A C D \\
23-34 W-16 A C B \\
23-34 W-26 C B C C\end{array}$ & $\begin{array}{l}1.4 \\
1.3 \\
1.6 \\
1.5 \\
1.6\end{array}$ & $\begin{array}{l}600 \\
610 \\
650 \\
580 \\
620\end{array}$ & $\begin{array}{l}\text { Medium } \\
\text { do. } \\
\text { do. } \\
\text { do. } \\
\text { do. }\end{array}$ & $\begin{array}{l}\text { Low } \\
\text { Do. } \\
\text { Do. } \\
\text { Do. } \\
\text { Do. }\end{array}$ \\
\hline $\begin{array}{l}6 \\
7\end{array}$ & $\begin{array}{l}\text { Do. } \\
\text { Do. }\end{array}$ & $\begin{array}{l}24-33 W-9 C C D 3 \\
24-33 W-19 D B D D\end{array}$ & $\begin{array}{r}.9 \\
1.5\end{array}$ & $\begin{array}{l}470 \\
460\end{array}$ & $\begin{array}{l}\text { do. } \\
\text { do. }\end{array}$ & $\begin{array}{l}\text { Do. } \\
\text { Do. }\end{array}$ \\
\hline $\begin{array}{l}8 \\
9\end{array}$ & $\begin{array}{c}\text { Ford } \\
\text { Do. }\end{array}$ & $\begin{array}{l}25-25 W-32 C D D \\
27-24 W-4 C A A\end{array}$ & $\begin{array}{l}2.2 \\
1.9\end{array}$ & $\begin{array}{l}540 \\
920\end{array}$ & $\begin{array}{l}\text { do. } \\
\text { High }\end{array}$ & $\begin{array}{l}\text { Do. } \\
\text { Do. }\end{array}$ \\
\hline 10 & Gray & $28-28 W-9 D B B$ & .6 & 440 & Medium & Do. \\
\hline $\begin{array}{l}11 \\
12 \\
13 \\
14 \\
15\end{array}$ & $\begin{array}{l}\text { Hamilton } \\
\text { Do. } \\
\text { Do. } \\
\text { Do. } \\
\text { Do. }\end{array}$ & $\begin{array}{l}21-40 W-17 C A D \\
21-42 W-3 C B B \\
21-42 W-14 D A C \\
22-41 W-33 D D C \\
23-39 W-29 D D D\end{array}$ & $\begin{array}{l}30 \\
35 \\
24 \\
5.0 \\
27\end{array}$ & $\begin{array}{r}1,180 \\
970 \\
1,150 \\
570 \\
2,700\end{array}$ & $\begin{array}{l}\text { High } \\
\text { do. } \\
\text { do. } \\
\text { Medium } \\
\text { Very high }\end{array}$ & $\begin{array}{l}\text { Very high } \\
\text { Do. } \\
\text { Do. } \\
\text { Low } \\
\text { Very high }\end{array}$ \\
\hline $\begin{array}{l}16 \\
17 \\
18 \\
19 \\
20\end{array}$ & $\begin{array}{l}\text { Do. } \\
\text { Do. } \\
\text { Do. } \\
\text { Do. } \\
\text { Do. }\end{array}$ & $\begin{array}{l}23-40 W-7 C C B \\
23-40 W-24 B A B \\
23-41 W-13 C C D \\
24-39 W-25 A A A \\
24-40 W-5 C B B\end{array}$ & $\begin{array}{l}7.6 \\
5.6 \\
2.2 \\
1.5 \\
5.2\end{array}$ & $\begin{array}{r}3,800 \\
1,010 \\
4,300 \\
820 \\
2,550\end{array}$ & $\begin{array}{l}\text { do. } \\
\text { High } \\
\text { Very high } \\
\text { High } \\
\text { Very high }\end{array}$ & $\begin{array}{l}\text { High } \\
\text { Medium } \\
\text { Low } \\
\text { Do. } \\
\text { Medium }\end{array}$ \\
\hline 21 & Do. & $26-43 W-33 \mathrm{CCC}$ & .8 & 570 & Medium & Low \\
\hline $\begin{array}{l}22 \\
23 \\
24\end{array}$ & $\begin{array}{c}\text { Kearny } \\
\text { Do. } \\
\text { Do. }\end{array}$ & $\begin{array}{l}22-35 W-4 D C C \\
24-36 W-23 C C C \\
24-36 W-29 A A A\end{array}$ & $\begin{array}{l}8.7 \\
1.7 \\
3.8\end{array}$ & $\begin{array}{l}630 \\
400 \\
740\end{array}$ & $\begin{array}{l}\text { do. } \\
\text { do. } \\
\text { do. }\end{array}$ & $\begin{array}{l}\text { Medium } \\
\text { Low } \\
\text { Do. }\end{array}$ \\
\hline
\end{tabular}




\section{Drinking Water and Public-Water Supplies}

The chemical concentrations and the recommended maximum constituent values that are important in determining the water's suitability for drinking and public-water supplies (U.S. Environmental Protection Agency, 1976; 1979) are as follows:

Chemical constituent or
physical property

Arsenic

Barium

Cadmi um

Chloride

Chromium

Color

Copper

Corrosivity

Dissolved solids

Fluoride

Foaming agents

Iron

Lead

Manganese

Mercury

Nitrate (as N)

odor

$\mathrm{pH}$

Selenium

Silver

Sulfate

Zinc
Concentration [milligrams per per liter $(\mathrm{mg} / \mathrm{L})$, except as noted]

1 Temperature/volume injested dependent.

The esthetic quality of drinking water, such as taste, odor, color, and appearance, are important factors in the public acceptance and confidence in publicwater supplies.

Based on the chemical analyses of water collected during this study (table 4), water from the Jurassic aquifer in Hamilton and Kearny Counties was unsuitable for drinking and public supply. The unsuitable water had large concentrations of dissolved solids, sulfate, chloride, and cadmium that exceeded the recommended or mandatory maximum values.

Based on the chemical analyses of water collected during this study (table 4), water from the Cheyenne aquifer ranged from suitable in Kearny County and parts of Hamilton County to unsuitable in parts of Hamilton County for drinking and public supply. The unsuitable water had large concentrations of dissolved solids, sulfate, and chloride that exceeded the recommended maximum or mandatory values. 
Based on the chemical analyses of water collected during this study (table 4), the water from the Dakota aquifer ranged from generally suitable in the study area to unsuitable in parts of Hamilton County for drinking and public supply. The unsuitable water had large concentrations of dissolved solids, sulfate, chloride, and fluoride that exceeded the recommended or mandatory maximum values.

\section{SUMMARY}

During 1979-82, a geohydrologic and chemical quality-of-water study, done in cooperation with the Kansas Department of Health and Environment, of permeable units in Middle and Upper Jurassic and Lower Cretaceous rocks was conducted in western Kansas. The 15-county study comprised about 12,700 $\mathrm{mi}^{2}$.

Three test wells were constructed by re-entering, drilling out plugging materials, and washing out the casings of abandoned $0 i 1$ and gas exploration wells. The casings were perforated at selected intervals; water samples were collected; and water levels were measured.

Middle and Upper Jurassic rocks include rocks equivalent to the undifferentiated Entrada Sandstone and Morrison Formation. Jurassic rocks consists of varicolored sandstone, siltstone, shale, and limestone of a continental and fluvial origin. The rocks range in thickness from about zero to more than $200 \mathrm{ft}$ and occur at depths varying from about 300 to more than $2,500 \mathrm{ft}$.

Lower Cretaceous rocks include the Cheyenne Sandstone, Kiowa Formation, and Dakota Formation. Cheyenne rocks consist of white, brown, and gray, very fine to medium-grained sandstone and dark-gray shale of marine origin. Cheyenne rocks occur at depths ranging from about 200 to $2,500 \mathrm{ft}$ and vary in thickness from about zero to more than $200 \mathrm{ft}$. kiowa rocks consist of light-gray to black shale, with interbedded siltstone, sandstone, and limestone of marine origin. Kiowa rocks vary in depth from about 180 to more than $1,800 \mathrm{ft}$ and vary in thickness from about zero to more than $190 \mathrm{ft}$. Dakota rocks consist of white, gray, or brown sandstone, with interbedded varicolored shales and siltstones of marine or nonmarine origin. Dakota rocks occur at the land surface to depths of more than 2,000 ft and range in thickness from about zero to $400 \mathrm{ft}$.

The Jurassic artesian aquifer consists of saturated permeable sandstone and siltstone units and has a maximum thickness of about $50 \mathrm{ft}$. In the three test wells in Hamilton and Kearny Counties, water levels in the Jurassic aquifer during September-November 1981 ranged from 255 to 1,160 $\mathrm{ft}$ below land surface, and static heads ranged from 2,408 to 3,090 ft above the National Geodetic Vertical Datum of 1929. The hydraulic gradient varied from $16 \mathrm{ft} / \mathrm{mi}$ toward the northeast to $40 \mathrm{ft} / \mathrm{mi}$ toward the north.

The Cheyenne artesian aquifer consists of saturated permeable sandstone units and has a maximum thickness of about $190 \mathrm{ft}$. In the three test wells in Hamilton and Kearny Counties, water levels in the Cheyenne aquifer during October-November 1981 ranged from 267 to $375 \mathrm{ft}$ below land surface, and 
static heads varied from less than 2,300 to more than 3,200 ft above the National Geodetic Vertical Datum of 1929. The hydraulic gradient was 8 $\mathrm{ft} / \mathrm{mi}$ toward the east. The Cheyenne aquifer is confined by the overlying shale of the Kiowa Formation.

The Dakota artesian aquifer consists of saturated permeable sandstone units and has a maximum thickness of about $150 \mathrm{ft}$. Water levels in selected observation wells ranged from 24 to $604 \mathrm{ft}$ below land surface during MarchMay 1982. Static heads ranged from about 2,100 to $3,200 \mathrm{ft}$ above the National Geodetic Vertical Datum of 1929. The hydraulic gradient was 11 $\mathrm{ft} / \mathrm{mi}$ toward the east and northeast. Transmissivity ranged from 100 to $2,100 \mathrm{ft}^{2} / \mathrm{d}$, and the storage coefficient ranged from $1 \times 10^{-4}$ to $4 \times$ 10-3. Large-capacity wells commonly yielded from about 150 to 1,200 gal/min.

Water in the Jurassic, Cheyenne, and Dakota aquifers has been developed for various uses that have included domestic, stock, irrigation, publicsupply, and industrial uses. The Jurassic and Cheyenne aquifers have had very little well development. Small-capacity domestic and stock wells have been completed in the Cheyenne aquifer in Hamilton County. The Dakota has had significant well development, but in many localities, the wells are widely spaced so that the aquifer is still considered to be underdeveloped. Large-capacity irrigation, public-supply, and industrial well development in the Dakota aquifer has occurred in the vicinity of Dodge City, Holcomb, Jetmore, Johnson, Lakin, Montezuma, Spearville, Syracuse, and Ulysses.

Water from the Jurassic aquifer in Hamilton and Kearny Counties is moderately saline, very hard, and unsuitable for drinking, public supply, and irrigation. Sodium sulfate and sodium chloride are the chemical types of water.

Water from the Cheyenne aquifer in Hamilton and Kearny Counties ranges from fresh to moderately saline, and from soft to very hard. Sodium sulfate and sodium bicarbonate are the chemical types of water. The water ranges from suitable for irrigation, drinking, public supply in Kearny County to unsuitable for irrigation, drinking, and public supply in parts of Hamilton County. However, the water is suitable for drinking and public supply in parts of Hamilton County.

Water from the Dakota aquifer generally ranges from fresh to moderately saline, from soft to very hard, and from suitable to unsuitable for irrigation, drinking, industrial uses, and public supply. Sodium bicarbonate and calcium bicarbonate are the predominant chemical types of water. Calcium sulfate, sodium chloride, and sodium sulfate are local minor types of water.

Most of the saline water in the Jurassic, Cheyenne, and Dakota aquifers probably leaked from the underlying shales, red beds, and evaporite beds in Permian rocks. 


\section{SELECTED REFERENCES}

Brown, Eugene, Skougstad, M. W., and Fishman, M. J., 1970, Methods for collection and analysis of water samples for dissolved minerals and gases: U.S. Geological Survey Techniques of Water-Resources Investigations, Book 5, Chapter Al, $160 \mathrm{p}$.

Burns and McDonnel1, Inc., 1977, Report on the groundwater resources investigation of the Spratt site, for the proposed coal-fired generating plant for the Sunflower Electric Cooperative: Kansas City, Mo., Burns and McDonnell, Inc.

Dealy, M. T., Kume, Jack, and Jenkins, E. D., 1984, Hydrogeology and development of the Dakota aquifer in southwest Kansas, in Proceedings of the Dakota Aquifer Symposium, Lincoln, Nebraska, October 5-6, 1982: National Water Well Association, [in press].

Edmund, R. W., and Goebel, E. D., 1968, Subsurface waste-disposal potential in Salina basin of Kansas, in Galley, J. E., ed., Subsurface disposal in geologic basins--A study of reservoir strata: American Association Petroleum Geologist Memoir 10, p. 154-164.

Franks, P. C., 1975, The transgressive-regressive sequence of the Cretaceous Cheyenne, Kiowa, and Dakota Formations of Kansas: Geological Association of Canada Special Paper 13, p. 469-521.

Feth, J. H., 1981, Chloride in natural continental water--A review: U.S. Geological Survey Water-Supply Paper 2176, $30 \mathrm{p}$.

Garbarini, G. S., and Veal, H. K., 1968, Potential of Denver basin for disposal of liquid wastes, in Galley, J. E., ed., Subsurface disposal in geologic basins--A study of reservoir strata: American Association Petroleum Geologists Memoir 10, p. 165-185.

Gary, Margaret, McAfee, Robert, Jr., and Wolf, C. L., eds., 1972, Glossary of geology: Washington, D.C., American Geological Institute, 805 p.

Gogel, Tony, 1981, Discharge of saltwater from Permian rocks to major stream-aquifer systems in central Kansas: Kansas Geological Survey Chemical Quality Series 9, 60 p.

Gutentag, E. D., Lobmeyer, D. H., and Slagle, S. E., 1981, Geohydrology of southwestern Kansas: Kansas Geological Survey Irrigation Series $7,73 \mathrm{p}$.

Hathaway, L. R., Carr, B. L., Flanagan, M. A., Galle, 0. K., Waugh, T. C., Dickey, H. P., and Magnuson, L. M., 1978, Chemical quality of irrigation waters in southwestern Kansas: Kansas Geological Survey Chemical Quality Series 6, 35 p.

Hem, J. D., 1970, Study and interpretation of the chemical characteristics of natural water (2d ed.): U.S. Geological Survey Water-Supply Paper 1473, $363 \mathrm{p}$. 
Irwin, J. H., and Morton, R. B., 1969, Hydrogeologic information on the Glorieta Sandstone and the Ogallala Formation in the Oklahoma Panhandle and adjoining areas as related to underground waste disposal: U.S. Geological Survey Circular 630, 26 p.

Kansas Department of Health and Environment, 1982, Groundwater quality management plan for the State of Kansas: Kansas Department of Health and Environment Bulletin 3-4, $77 \mathrm{p}$.

Kansas State Corporation Commission, 1979, General rules and regulations for the conservation of crude oil and natural gas: Wichita, Kansas State Corporation Commission, $48 \mathrm{p}$.

Keene, K. M., and Bayne, C. K., 1977, Ground water from Lower Cretaceous rocks in Kansas: Kansas Geological Survey Chemical Quality Series 5, $18 \mathrm{p}$.

Keys, W. S., and MacCary, L. M., 1971, Application of borehole geophysics to water-resources investigations: U.S. Geological Survey Techniques of Water-Resources Investigations, Book 2, Chapter El, 126 p.

Kume, Jack, and Spinazola, J. M., 1982, Geohydrologic data from sandstone aquifers in southwestern Kansas: U.S. Geological Survey Open-File Report 82-868, 112 p.

1983, Maps showing depth and thickness of selected units in Upper Permian, Upper Jurassic, and Lower Cretaceous rocks in southwestern Kansas: U.S. Geological Survey Water-Resources Investigations Report 83-4095, scale 1: 500,000, 7 sheets.

1984, Geohydrology of sandstone aquifers in southwestern Kansas: Kansas Geological Survey Irrigation Series 8 [in press].

Leonard, R. B., 1964, A method for evaluating oil-field brine pollution of the Walnut River in Kansas: U.S. Geological Survey Professional Paper 501-B, P. B173-B176.

Lobmeyer, D. H., and Weakly, E. C., 1979, Water in the Dakota Formation, Hodgeman and northern Ford Counties, southwestern Kansas: Kansas Geological Survey Irrigation Series 5, $41 \mathrm{p}$.

Lohman, S. W., 1979, Ground-water hydraulics: U.S. Geological Survey Professional Paper 708, $70 \mathrm{p}$.

Lohman, S. W., and others, 1972, Definitions of selected ground-water terms--Revisions and conceptual refinements: U.S. Geological Survey Water-Supply Paper 1988, 21 p.

McGowen, J. H., Granata, G. E., and Seni, S. J., 1979, Depositional framework of the Lower Dockum Group (Triassic) Texas Panhandle: Texas Bureau of Economic Geology Report of Investigations 97, 60 p.

Merriam, D. F., 1955, Jurassic rocks in Kansas: American Association of Petroleum Geologists Bulletin, v. 39, no. 1, p. 31-46. 
1957, Preliminary regional structural contour map on top of the Dakota Formation (Cretaceous) in Kansas: Kansas Geological Survey $0 i 1$ and Gas Investigations No. 15, scale 1:600,000, map.

1963, The geologic history of Kansas: Kansas Geological Survey Bullet in 162, $317 \mathrm{p}$.

Pabst, M. E., 1982, January 1982 water levels, and data related to waterlevel changes, western and south-central Kansas: U.S. Geological Survey Open-File Report 82-649, $167 \mathrm{p}$.

Schoon, R. A., 1971, Geology and hydrology of the Dakota Formation in South Dakota: South Dakota Geological Survey Report of Investigations $104,55 \mathrm{p}$.

Skougstad, M. W., Fishman, M. J., Friedman, L. C., Erdmann, D. E., and Duncan, S. S., eds., 1979, Methods for determination of inorganic substances in water and fluvial sediments: U.S. Geological Survey Techniques of Water-Resources Investigations, Book 5, Chapter A1, 626 p.

U.S. Environmental Protection Agency, 1976, National interim primary drinking water regulations: Office of Water Supply, EPA-570/9-76-003, 159 p.

1979, National Secondary Drinking Water Regulations: Federal Register, v. 44 , no. 140 , p. $42195-42202$.

U.S. Salinity Laboratory Staff, 1954, Diagnosis and improvement of saline and alkali soils: U.S. Department of Agriculture, Agriculture Handbook $60,160 \mathrm{p}$.

Voegeli, P. T., and Hershey, L. A., 1965, Geology and ground-water resources of Prowers County, Colorado: U.S. Geological Survey Water-Supply Paper 1772, $101 \mathrm{p}$.

Weist, W. G., Jr., 1963, Water in the Dakota and Purgatoire Formations in Otero County and the southern part of Crowley County, Colorado: U.S. Geological Survey Water-Supply Paper 1669-P, 17 p.

White, D. E., Hem, J. D., and Waring, G. A., 1963, Chemical composition of subsurface water, in Data of geochemistry: U.S. Geological Survey Professional Paper $44 \overline{0-F}, 67 \mathrm{p}$.

Whittemore, D. 0., Basel, C. L., Galle, 0. K., and Waugh, T. C., 1981, Geochemical identification of saltwater sources in the Smoky Hill River valley, McPherson, Saline, and Dickinson Counties, Kansas: Kansas Geological Survey Open-File Report 81-6, 78 p.

Wood, W. W., 1976, Guidelines for collection and field analysis of groundwater samples of selected unstable constituents: U.S. Geological Survey Techniques of Water-Resources Investigations, Book 1, Chapter D2, 24 p.

Zeller, D. E., ed., 1968, The stratigraphic succession in Kansas: Kansas Geological Survey Bulletin 189, 81 p. 